Federal Reserve Bank of Dallas

Globalization and Monetary Policy Institute

Working Paper No. 314

https://www.dallasfed.org/ /media/documents/institute/wpapers/2017/0314.pdf

\title{
Financial Globalisation, Monetary Policy Spillovers and Macro-modelling: Tales from 1001 Shocks*
}

\author{
Georgios Georgiadis \\ European Central Bank \\ Martina Jančoková \\ European Central Bank
}

May 2017

\begin{abstract}
Financial globalisation and spillovers have gained immense prominence over the last two decades. Yet, powerful cross-border financial spillover channels have not become a standard element of structural monetary models. Against this background, we hypothesise that New Keynesian DSGE models that do not feature powerful financial spillover channels confound the effects of domestic and foreign disturbances when confronted with the data. We derive predictions from this hypothesis and subject them to data on monetary policy shock estimates for 29 economies obtained from more than 280 monetary models in the literature. Consistent with the predictions from our hypothesis we find: Monetary policy shock estimates obtained from New Keynesian DSGE models that do not account for powerful financial spillover channels are contaminated by a common global component; the contamination is more severe for economies that are more susceptible to financial spillovers in the data; and the shock estimates imply implausibly similar estimates of the global output spillovers from monetary policy in the US and the euro area. None of these findings applies to monetary policy shock estimates obtained from VAR and other statistical models, financial market expectations and the narrative approach.
\end{abstract}

JEL codes: F42, E52, C50

* Georgios Georgiadis, European Central Bank, 60311 Frankfurt am Main, Germany. georgios.georgiadis@ecb.int. Martina Jančoková, European Central Bank, 60311 Frankfurt am Main, Germany. martina.jancokova@ecb.int. We would like to thank a large number of researchers for sharing their data and codes as well as providing valuable comments. As the number of names exceeds the space available here we list them in a separate section in the Appendix of this paper. The database of monetary policy shock estimates gathered for the purpose of this paper is available from our websites. Researchers using specific shock time series from the database are kindly asked to also quote the original source. None of the monetary policy shock estimates used in this paper represent the views of the central banks, international organisations, ministries and their policy committees. The views in this paper are those of the authors and do not necessarily reflect the views of the European Central Bank, The Eurosystem, the Federal Reserve Bank of Dallas or the Federal Reserve System. 


\section{Introduction}

A salient feature of the global economy since the 1990s has been the dramatic rise of financial globalisation. Whether measured by (gross) capital flows or indicators reflecting the extent of legal capital account restrictions, economies' financial markets have been exhibiting an increasing degree of integration. As a result, the global economy is progressively becoming subject to large cross-country spillovers through financial channels, in particular in case of monetary policies in systemic economies. Indeed, a growing body of empirical research provides evidence that financial interlinkages play a critical role in the transmission of shocks across economies (Ehrmann and Fratzscher, 2003, 2005, 2009; Ehrmann et al., 2011; Hale et al., 2016). Similarly, several studies document the sizable impact of - in particular USmonetary policy on output and inflation in the rest of the world that materialises through financial spillover channels (Kim, 2001; Canova, 2005; Nobili and Neri, 2006; Dedola et al., 2015; Feldkircher and Huber, 2015; Georgiadis, 2016). And related work even suggests that economies' financial markets are subject to a global financial cycle, which is argued to materialise in variations in global risk aversion and to be driven by US monetary policy (Bekaert et al., 2013; Ghosh et al., 2014; Bruno and Shin, 2015b,a; Miranda-Agrippino and Rey, 2015; Passari and Rey, 2015; Rey, 2015).

At the same time, over the last two decades important advances in structural monetary modelling have been achieved, as reflected in the huge amount of work on New Keynesian dynamic stochastic general equilibrium (NK DSGE) models. While the first NK DSGE models focused on frictions in price setting and labor markets (Smets and Wouters, 2003; Christiano et al., 2005), the global financial crisis epitomised the role of frictions in financial markets for the propagation of shocks. The resulting wave of work has focused on introducing frictions in domestic financial markets (Gertler and Karadi, 2011; Christiano et al., 2014). Advances have also been made in generalising the initially closed-economy NK DSGE models to analyse the international transmission of shocks and policy design in open economies, giving rise to New Open-Economy Macroeconomics (Obstfeld and Rogoff, 1996). After two decades of continuous development and research it is fair to say that NK DSGE models have become standard elements of macroeconomists' toolbox. In particular at central banks elaborate versions of NK DSGE models are routinely used, for example in order to determine what shocks have been drivers of recent business cycle movements. This is an important exercise, as the appropriate policy response to business cycle fluctuations depends on what type of shocks are driving the economy. Against the background of the continuous strengthening of cross-border financial integration, it is noteworthy that powerful spillover channels based on frictions in international financial markets - for example involving cross-border interbank balance sheet exposures, collateral constraints and currency mismatches - are not routinely incorporated in NK DSGE models. ${ }^{1}$ Possible consequences of this particular discrepancy

\footnotetext{
${ }^{1}$ NK DSGE models that do consider frictions in international financial markets include Devereux and
} 
between empirics and theory have not been explored systematically yet. We aim to fill part of this gap in the literature.

In this paper we hypothesise that the structural monetary models used in the profession typically fail to adequately account for the importance of financial spillover channels in the data. We argue that, as a consequence, when confronted with the data these models label restof-the-world monetary policy shocks as domestic ones. We test this hypothesis by verifyingin a meta-study-like fashion - if three predictions are borne out by the NK DSGE models used in the literature. Specifically, under our hypothesis we expect: First, domestic monetary policy shock estimates are contaminated by a common global component and are therefore positively correlated across economies. ${ }^{2}$ Second, the contamination by the common global component is more severe and thereby gives rise to larger cross-country correlations for pairs of economies that are more strongly integrated with global financial markets. Third, estimates of the global spillovers from domestic monetary policy obtained using shock estimates from NK DSGE models in time-series regressions are implausibly similar across spillover-sending economies, as they all reflect the response to a common global monetary policy shock.

We provide empirical evidence that is consistent with the predictions from our hypothesis based on a database of monetary policy shock estimates for 29 economies obtained from more than 280 structural and non-structural monetary models used in the literature for the time period from 1993 to 2007. First, we document that when confronted with the data NK DSGE models produce domestic monetary policy shock estimates that are positively correlated across economies. In contrast, monetary policy shock estimates obtained from VAR and other statistical models, derived from financial market expectations and the narrative approach are essentially cross-country uncorrelated. Interestingly, we document that the contamination by a common global component is as severe for monetary policy shock estimates obtained from NK DSGE models used at central banks and international organisations as for shock estimates obtained from stylised NK DSGE models used in academia. Second, the cross-country correlations between monetary policy shock estimates obtained from NK DSGE models are larger for economies that are more strongly integrated with global financial markets. Importantly, this finding is robust to accounting for other possible explanations for the cross-country correlations between monetary policy shock estimates, such as mis-specification of the Taylor-rule or failure to account for spillovers through trade. Third, using shock estimates obtained from NK DSGE models in time-series regressions produces estimates for the global output spillovers from US and euro area monetary policy which are implausibly

Yetman (2010), Kollmann et al. (2011), Dedola and Lombardo (2012), Ueda (2012), Banerjee et al. (2016) as well as Nuguer (2016).

${ }^{2}$ That the true structural shocks are uncorrelated is impossible to verify, but is a fundamental assumption in macroeconomics. For example, Bernanke (1986) states that "shocks should be primitive exogenous forces that are uncorrelated with each other", as only un-correlatedness allows a meaningful interpretation of impulse response functions and variance decompositions. Andrle (2014) discusses in detail the notion that (crosscountry) correlated estimates of structural shocks are a sign of model mis-specification in NK DSGE models. 
similar. In contrast, the relative magnitudes of the estimates of the global output spillovers from monetary policy in the US and the euro area obtained from time-series regressions are more plausible when using shock estimates that stem from non-NK DSGE models.

Our paper is related to the literature which is concerned with the role of powerful financial spillover channels in structural monetary models for cross-country business cycle correlations (Iacoviello and Minetti, 2006; Ueda, 2012; Yao, 2012; Chin et al., 2015). Within this literature, our paper is most closely related to Justiniano and Preston (2010) as well as Alpanda and Aysun (2014), who find that standard open-economy NK DSGE models fail to replicate the large degree of cross-country business cycle co-movement in the data, and that they imply only an implausibly minor role of foreign disturbances for the evolution of domestic variables. More specifically, these studies find that the theoretical moments implied by standard NK DSGE models - which do not account for powerful financial spillover channels - are much closer to their empirical counterparts if it is assumed that the structural shocks are cross-country correlated. This finding is typically interpreted as suggesting that standard NK DSGE models lack empirically relevant cross-border transmission channels for country-specific shocks or a global dimension that would allow to consider common shocks. This interpretation is consistent with the finding in this paper that NK DSGE models that do not account for powerful financial spillover channels produce cross-country correlated monetary policy shock estimates. At the same time, our findings of course do not imply that the lack of financial spillover channels is the only - or even the most important - source of mis-specification in standard NK DSGE models. Finally, while the analyses of Justiniano and Preston (2010) as well as Alpanda and Aysun (2014) are based on counterfactual simulations of two specific structural models, in this paper we consider a database of monetary policy shock estimates from more than 280 monetary - including non-structural-models estimated for a range of economies.

The empirical evidence we obtain in this paper is also consistent with several additional predictions from our hypothesis. First, the evidence supports the hypothesis of a global financial cycle that is driven by US monetary policy (Bekaert et al., 2013; Bruno and Shin, 2015b,a; Miranda-Agrippino and Rey, 2015; Passari and Rey, 2015; Rey, 2015). Specifically, a prediction from the global financial cycle hypothesis in the light of our paper is that monetary policy shock estimates from NK DSGE models which do not feature powerful financial spillover channels should be contaminated by a US component. Indeed, we find that the cross-country correlations between the monetary policy shock estimates obtained from NK DSGE models for non-US economies are larger for country pairs that are more financially integrated with US - in addition to global - financial markets. Second, the evidence we obtain is also consistent with the important role of global banks in financial integration prior to the global financial crisis (Goldberg, 2009; Cetorelli and Goldberg, 2012; Bruno and Shin, 2015b,a; Morais et al., 2015). Specifically, we find that the contamination by a common global component is particularly severe for monetary policy shock estimates for economies which are 
more financially integrated through international banking linkages. Finally, we also obtain some tentative evidence that is consistent with the trilemma in international macroeconomics (Obstfeld et al., 2005; di Giovanni and Shambaugh, 2008; Klein and Shambaugh, 2015; Obstfeld, 2015): The contamination by a common global component is less severe for monetary policy shock estimates for emerging market economies which impose capital controls and which feature flexible exchange rate regimes.

Failure to account for the global context and powerful financial spillover channels in NK DSGE models may imply inconsistent parameter estimates obtained by likelihood-based methods, as the monetary policy shock estimates entering the likelihood function are mis-measured. Moreover, mis-measured monetary policy shock estimates imply incorrect variance and historical decompositions. Ultimately, this might lead to mis-leading policy recommendations. Having said that, it is important to emphasise that our paper is not to be read as a general critique or dismissal of the use of NK DSGE models in the profession. Consistent with the view of Blanchard (2016), we believe that NK DSGE models "are eminently improvable and central to the future of macroeconomics", and that whether specific elements - such as powerful financial spillover channels - are necessary depends on the purpose the models are used for. The insights from our paper suggest that more efforts need to be devoted to the modelling of the global context as well as powerful financial spillover channels in structural monetary models that are used for policy analysis, especially at central banks and international organisations. Indeed, we also find that the contamination by a common global component is less severe if the monetary policy shock estimates stem from NK DSGE models that do feature an explicit multi-country dimension and/or frictions in international financial markets. Which particular frictions in cross-border financial markets are the most appropriate to be introduced into NK DSGE models to mitigate the contamination by a common global component most plausibly depends on country specifics, and we leave this investigation for future research.

The rest of this paper is organised as follows. In Section 2, we illustrate the mechanics of our hypothesis and derive testable predictions from a stylised counterfactual Monte Carlo experiment. In Section 3 we present our monetary policy shock database and test the predictions from our hypothesis derived in Section 2. Section 4 presents additional testable predictions, competing hypotheses that may explain the positive cross-country correlations between the NK DSGE model monetary policy shock estimates in our database as well as robustness checks. Finally, Section 5 concludes. 


\section{Financial globalisation, monetary policy spillovers and struc- tural macro-modeling}

In this section we consider a counterfactual Monte Carlo experiment in order to motivate our hypothesis. Specifically, the Monte Carlo experiment consists of three steps. First, we simulate data based on a structural multi-country model with financial spillover channels and cross-country uncorrelated monetary policy shocks. The model features "core" (the US) and "non-core" (the euro area and Japan) economies which differ in the magnitude of the financial spillovers they emit. Second, we obtain estimates of the monetary policy shocks for the euro area and Japan by feeding the simulated data into intentionally mis-specified single-country versions of the true data-generating process; specifically, the single country models do not feature financial spillover channels. Third, we determine the cross-country correlation between the monetary policy shock estimates for the non-core economies of the euro area and Japan obtained in step two. We also utilise the shock time series estimates to obtain estimates of the spillovers from monetary policy in the euro area (or Japan) to the US using local projections. We run the Monte Carlo experiment for different parameterisations of the data-generating process in order to assess the role of the strength of financial spillovers for the properties of the monetary policy shock estimates. It is important to emphasise that we consider this Monte Carlo experiment in order to illustrate how failure to account for financial spillover channels can give rise to cross-country correlated monetary policy shock estimates, and not in order to establish that this is the only possible reason for cross-country correlated monetary policy shock estimates. We explore alternative explanations for crosscountry correlated monetary policy shock estimates in Section 4.

\subsection{The data-generating process}

The basic building blocks of the multi-country model of Coenen and Wieland (2002) are an IS-curve, a Phillips curve, an uncovered interest rate parity condition, and a Taylor-rule for each economy. ${ }^{3}$ Importantly, we specify the monetary policy shocks in the data-generating process to be uncorrelated across economies. We introduce a financial spillover channel by modifying the original specification of nominal long-term interest rates $i_{i t}^{(l)}$ through the term structure in Coenen and Wieland (2002) and consider

$$
i_{i t}^{(l)}=\left(1-\vartheta_{i}\right) \cdot\left(\frac{1}{8} \sum_{\ell=0}^{7} E_{t} i_{i, t+\ell}^{(s)}\right)+\vartheta_{i} \cdot\left(\sum_{j=1, j \neq i}^{N} \omega_{i j} i_{j t}^{(l)}\right),
$$

\footnotetext{
${ }^{3}$ The model of Coenen and Wieland (2002) is semi-structural: The components are not explicitly derived from micro-founded optimisation problems, but are very similar to those in rigorously constructed structural monetary models. Appendix C.2 provides a detailed description of the model.
} 
where $i, j \in\{u s, e a, j a\}, i_{i t}^{(s)}$ represents the nominal short-term interest rate, and $w_{i j}$ denotes bilateral weights. The second term on the right-hand side of Equation (1) gives rise to potentially powerful financial spillovers. Specifically, the higher $\vartheta_{i}$, the stronger the spillovers from foreign to domestic long-term interest rates. Analogously, the higher $\omega_{i j}$, the stronger the spillovers to domestic long-term interest rates in economy $i$ from economy $j$ relative to those from other foreign economies $s, s \neq i, j$. This specification of financial spillovers through long-term interest rates is consistent with their strong co-movement in the data (see, for example, Ehrmann and Fratzscher, 2003, 2005; Ehrmann et al., 2011; Chin et al., 2015).

We examine two polar parameterisations for $\vartheta_{i}$ and $\omega_{i, u s}$ in Equation (1), namely a "no financial spillovers" and a "financial spillovers" parametrisation. In the "no financial spillovers" parametrisation we set $\vartheta_{i}=\omega_{i, u s}=0$. In the "financial spillovers" parametrisation we set $\vartheta_{i}=0.2$ and $\omega_{i, u s}=0.8$. For the US we fix $\vartheta_{u s}=0.2$ and $w_{u s, j}=0.5$, reflecting our assumption of the US being the core economy. The dynamics of domestic and foreign variables in response to monetary policy shocks under the two polar parameterisations are qualitatively plausible and - in particular for the "financial spillovers" parametrisation-consistent with the findings on monetary policy spillovers in the empirical literature (see Figures 7 and 8 in Appendix C.2 as well as Dedola et al., 2015; Feldkircher and Huber, 2015; Banerjee et al., 2016; Chen et al., 2016; Georgiadis, 2016).

\subsection{Cross-country correlations of monetary policy shocks}

Figure 1 presents the distribution of the cross-country correlations between the monetary policy shock estimates for the non-core economies of the euro area and Japan obtained from feeding the data simulated from the multi-country data-generating process into the corresponding single-country versions across the 1,000 replications of the Monte Carlo experiment. Under the "no financial spillovers" parametrisation, the cross-country correlations are not noticeably (and statistically significantly) different from zero, which is in line with the absence of such correlation in the data-generating process. In contrast, under the "financial spillovers" parametrisation the cross-country correlations are large and positive, with a mean of around 0.2 across replications. Thus, using single-country models that do not adequately account for the presence of powerful financial spillover channels in the data-generating process produces domestic monetary policy shock estimates which are positively cross-country correlated.

In order to identify the source of this correlation, we run the regression

$$
\widehat{e}_{e a, t}^{m p}=\sum_{i \in e a, u s, j a}\left(\beta_{i}^{m p} \cdot e_{i t}^{m p}+\beta_{i}^{d} \cdot e_{i t}^{d}+\beta_{i}^{c p} \cdot e_{i t}^{c p}\right)+u_{i t},
$$

where $\widehat{e}_{e a, t}^{m p}$ represents the euro area monetary policy shock estimates obtained from the singlecountry model, and $e_{i t}^{m p}, e_{i t}^{d}$, and $e_{i t}^{c p}$ denote the true monetary policy, demand and cost-push 
shocks. ${ }^{4}$ Figure 2 presents the distribution of the coefficient estimates $\widehat{\beta}_{i}^{\ell}$ in Equation (2) across replications of the Monte Carlo experiment. The results suggest that in particular under the "financial spillovers" parametrisation the estimate of the euro area monetary policy shock $\widehat{e}_{e a, t}^{m p}$ obtained from the single-country model is a convolution of the true monetary policy, demand and cost-push shocks of the euro area, the US and Japan. Most importantly, the true US monetary policy shock exhibits the largest loading on the estimated euro area monetary policy shock besides the true euro area monetary policy shock; the results for the regression of $\hat{e}_{j p, t}^{m p}$ are analogous. Thus, the cross-country correlation between the estimated monetary policy shocks of the euro area and Japan arises due to a common US component. In particular, the contamination of domestic monetary policy shock estimates by a US component occurs because (i) in the true data-generating process a US monetary policy shock spills over to domestic financial markets in the euro area and Japan according to Equation (1); (ii) when using the mis-specified single-country models for the non-core economies of the euro area and Japan for the estimation of the monetary policy shocks, the US monetary policy shock is erroneously labelled as domestic monetary policy shock.

\subsection{Spillover estimates}

In each replication of the Monte Carlo experiment we estimate spillovers from euro area monetary policy to the US using local projections (Jorda, 2005). Specifically, we estimate

$$
y_{u s, t+h}=\alpha^{(h)}+\sum_{k=0}^{p} \gamma_{k}^{(h)} \widehat{e}_{e a, t-k}^{m p}+\sum_{k=1}^{n} \delta_{k}^{(h)} y_{u s, t-k}+\sum_{k=0}^{q} \boldsymbol{x}_{u s, t-k} \boldsymbol{\beta}_{k}^{(h)}+u_{u s, t}^{(h)},
$$

for $h=0,1, \ldots, H$, where $y_{u s, t+h}$ represents the US output gap and $\widehat{e}_{e a, t}^{m p}$ the euro area monetary policy shock estimates obtained from using the single-country model. The control variables in $\boldsymbol{x}_{u s, t}$ include inflation, short and long-term interest rates as well as the real effective exchange rate. The data for $y_{u s, t}$ and $\boldsymbol{x}_{u s, t}$ stem from the simulation of the multicountry data-generating process. In every replication of the Monte Carlo experiment we use the simulated data both to estimate the monetary policy shocks in the single-country models and for the controls in the estimation of the local projections in Equation (3).

Figure 3 presents the estimated spillovers from euro area monetary policy to the US output gap for the "no financial spillovers" (left-hand side panel) and the "financial spillovers" (righthand side panel) parametrisation. The black solid lines represent the true spillovers in the data-generating process, and the red dashed lines the averages and medians of the spillover estimates across replications of the Monte Carlo experiment. The results suggest that using domestic monetary policy shock estimates obtained from a single-country model that does

\footnotetext{
${ }^{4}$ We standardise the time-series of all variables in Equation (2) in order to facilitate the comparison of the magnitudes of the coefficient estimates.
} 
not adequately account for the powerful financial spillover channels in the data produces excessively large estimates of the spillovers from euro area monetary policy to the US. The explanation for this result is that the euro area monetary policy shock estimates $\widehat{e}_{e a, t}^{m p}$ used in the local projections in Equation (3) contain a US component. Specifically, as the US component accounts for a large share of the variation in the euro area monetary policy shock estimates under the "financial spillovers" parametrisation, the estimates of spillovers from euro area monetary policy actually represent the effects of a US monetary policy shock on US variables; and, of course, in the true data-generating process the domestic effects of a US monetary policy shock are quantitatively significant (see Figure 7 in Appendix C.2). ${ }^{5}$

\subsection{Testable predictions}

We hypothesise that NK DSGE models used in the profession are generally subject to the same failure to account for financial spillovers as the single-country models in the counterfactual Monte Carlo experiment presented above. In the rest of this paper we thus test the following three predictions from our hypothesis:

Prediction 1: Monetary policy shock estimates obtained from NK DSGE models are positively cross-country correlated.

Prediction 2: The cross-country correlation is larger for country pairs which are more susceptible to financial spillovers.

Prediction 3: Estimating the global effects of domestic monetary policy using the monetary policy shock estimates obtained from NK DSGE models in time-series-such as local projection-regressions results in large and implausibly similar spillover estimates for different spillover-sending economies.

In order to test our hypothesis, we examine in a meta-study-like fashion whether Predictions 1-3 prevail in a sample of monetary policy shock estimates obtained from a wide range of NK DSGE and non-NK DSGE models in the literature.

\section{A monetary policy shock database}

The database we have set up contains more than 280 time series of monetary policy shock estimates. The monetary policy shock estimates pertain to 29 economies (see Table 1), and are obtained from estimated NK DSGE models, various blends of VAR models (structural VAR

\footnotetext{
${ }^{5}$ Analogously, the estimates of the spillovers from euro area monetary policy to Japan would in fact represent spillovers from US monetary policy to Japan, which are - due to the core properties of the US economy in our Monte Carlo experiment - notably larger than the true monetary policy spillovers from the euro area to Japan.
} 
and VECM models, factor-augmented VAR models, dynamic factor models), other statistical models (term-structure models, shadow-rate models, Taylor-rule estimations), approaches based on financial market expectations, as well as the narrative approach (see Table 2). Tables 3 to 6 provide information on the reference, the time period coverage, the model type and other characteristics of the models from which the monetary policy shock estimates are obtained. One noteworthy observation is that only few of the NK DSGE models from which the monetary policy shock estimates in our database stem have an explicit multi-country dimension in the sense that they feature a foreign block (see Table 7); even fewer models feature financial spillover channels based on frictions in international financial markets. The sample period we consider for the analysis in the rest of this paper is 1993q1 to 2007q2. We choose this period in order to maximise the length of the sample period while at the same time having the shock time-series estimates overlap pair-wise for reasonably similar time periods.

\subsection{Correlation patterns of monetary policy shock estimates}

We start testing the predictions from our hypothesis by examining the correlation patterns of the monetary policy shock estimates in our database. Figure 4 displays a heat map of the correlations between the monetary policy shock estimates obtained from NK DSGE models. The correlations between monetary policy shock estimates which stem from different NK DSGE models but pertain to the same economy are located on the diagonal blocks; the correlations between monetary policy shock estimates which stem from different NK DSGE models and pertain to different economies are located on the off-diagonal blocks. The top panel in Figure 5 shows the distribution of the cross-country correlations between monetary policy shock estimates which stem from NK DSGE models. The mean of the cross-country correlations is positive and statistically significantly different from zero. This evidence is consistent with the first prediction from our hypothesis.

Recall that we hypothesise that monetary policy shock estimates obtained from NK DSGE models are contaminated by a global component because the structure of these models typically does not account for economies' susceptibility to monetary policy spillovers from abroad through financial channels in the data. Given that we also have monetary policy shock estimates obtained from non-NK DSGE models in our database, we can carry out placebo tests of our hypothesis. Specifically, as non-NK DSGE models impose a looser structure on the data, the cross-country correlation between the corresponding monetary policy shock estimates obtained should be significantly smaller than for NK DSGE models. ${ }^{6}$ Accordingly, a placebo test of the first prediction from our hypothesis is shown in the second panel in Figure 5: The mean of the cross-country correlations between monetary policy shock estimates

\footnotetext{
${ }^{6}$ Indeed, when we estimate country-specific VAR models on the simulated data in the Monte Carlo experiment in Section 2 and apply recursive identification, the resulting monetary policy shock estimates for the euro area and Japan are on average uncorrelated.
} 
obtained from non-NK DSGE models is significantly smaller than in case of the NK DSGE models. ${ }^{7}$

One might argue that the mean of the cross-country correlations for the monetary policy shock estimates obtained from NK DSGE models displayed in the top panel in Figure 5-while being positive - is rather small, questioning the importance of this finding. However, recall that according to the second prediction from our hypothesis we expect contamination by a common global component and thereby the cross-country correlations to be quantitatively significantly larger than zero only for country pairs which are susceptible to financial spillovers, and thus not necessarily for all country pairs. The third panel in Figure 5 suggests that the evidence from our monetary policy shock estimates database is consistent with this prediction: The cross-country correlations are substantially larger for advanced economies, which are typically more financially integrated and thereby more susceptible to financial spillovers than emerging market economies; and the fourth panel shows that the cross-country correlations are even larger if we consider only pairs of economies which are particularly financially integrated. ${ }^{8}$ In the next section we explore the role of financial integration in the light of our hypothesis in more detail.

\subsection{The role of financial integration for cross-country correlations between monetary policy shock estimates}

According to the second prediction from our hypothesis, we expect contamination by a common global component and thereby the cross-country correlations to be larger for country pairs which are more susceptible to financial spillovers from abroad. Moreover, also consistent with the "global financial cycle" hypothesis (Rey, 2015), if the common component in the monetary policy shock estimates is largely driven by the core economy's monetary policy, we expect the cross-country correlations to be larger for pairs of economies which are more strongly integrated with US financial markets. In order to test these predictions, we consider country-pair regressions. Specifically, suppose we have monetary policy shock estimates for $N$ economies in our database. Furthermore, suppose that for economy $i$ we have a total of $L_{i}$ monetary policy shock estimates, and that we refer to one of those series by $\ell_{i}$; similarly, suppose we have a total of $M_{j}$ monetary policy shock estimates for economy $j$, and that we

\footnotetext{
${ }^{7}$ Of course one has to keep in mind the caveat that the finding that the monetary policy shock estimates from non-NK DSGE models are uncorrelated across economies does not necessarily imply that they reflect different objects. This point is made forcefully in the literature on the effects of monetary policy shocks in VAR models (see Bagliano and Favero, 1998; Sims, 1998).

${ }^{8} \mathrm{We}$ consider the median of economies gross foreign asset and liability position relative to GDP in our sample as cutoff.
} 
refer to one of those time series by $m_{j}$. We then estimate the regression

$$
\begin{gathered}
\rho_{\ell_{i}, m_{j}}=\alpha_{i}+\gamma_{j}+\boldsymbol{x}_{i j} \cdot \boldsymbol{\beta}+u_{\ell_{i}, m_{j}}, \\
i, j=1,2, \ldots, N, \quad i \neq j, \quad i, j \neq u s, \quad \ell_{i}=1,2, \ldots, L_{i}, \quad m_{j}=1,2, \ldots, M_{j},
\end{gathered}
$$

where $\alpha_{i}$ and $\gamma_{j}$ are country fixed effects, and $\boldsymbol{x}_{i j}$ includes measures of economy $i$ 's and $j$ 's combined susceptibility to financial spillovers from the rest of the world as well as the US. We measure the former by the product of economy $i$ 's and $j$ 's overall gross foreign asset and liability position relative to GDP, and the latter by the product of the shares of economy $i$ 's and $j$ 's bilateral gross foreign asset and liability position with the US in their overall external balance sheet. The data are taken from the External Wealth of Nations (EWN) Database of Lane and Milesi-Ferretti (2007) and the IMF's Coordinated Portfolio Investment Survey (CPIS). ${ }^{9}$ For easier interpretation we standardise the explanatory variables in Equation (4) based on the moments in the baseline sample. We run the regression of Equation (4) on the sample of cross-country correlations between monetary policy shock estimates obtained from NK DSGE models. Also, in the baseline regression sample we only include economies for which we have at least three NK DSGE model monetary policy shock time series estimates in our database; this we do in order to preclude that our results are driven by economies for which the information stems from a rather small number of models. Finally, we only include cross-country correlations that are calculated on the basis of at least 16 time series observations. Imposing these requirements implies dropping somewhat more than $10 \%$ of the cross-country correlations of monetary policy shock estimates from our sample. ${ }^{10,11}$

The estimation results for Equation (4) are reported in columns (1) to (3) in Table 8. Consistent with the second prediction from our hypothesis, the results indicate that the crosscountry correlations between monetary policy shock estimates obtained from NK DSGE models are higher for pairs of economies which are more susceptible to financial spillovers from the rest of the world and the US. The role of economies' susceptibility to financial spillovers for the mis-measurement of domestic monetary policy shock estimates in the NK DSGE models in our database is also quantitatively significant: The cross-country correlation between the monetary policy shock estimates for a pair of economies whose susceptibility to financial spillovers is one standard deviation above the mean of all country pairs is higher by 0.08 , which is approximately equal to the average cross-country correlation in our database (see Figure 5).

Finally, also the second prediction from our hypothesis passes the placebo test: The results

\footnotetext{
${ }^{9}$ Figure 9 in Appendix C.3 presents economies' overall and bilateral financial integration with the US in the data.

${ }^{10}$ We consider all correlations $\rho_{\ell_{i}, m_{j}}$ whether or not they are statistically significantly different from zero in the regression of Equation (4). Robustness checks in Section 4 document that our results are unchanged if we set to zero correlations which are not statistically significantly different from zero.

${ }^{11}$ In the estimation of the regression in Equation (4) we cluster standard errors at the country-pair level.
} 
reported in column (4) in Table 8 document that cross-country correlations between monetary policy shock estimates obtained from non-NK DSGE models are not systematically related to economies' susceptibility to financial spillovers. This finding is not due to (i) differences between the sets of country-pairs included in the sample underlying our baseline regression and the non-NK DSGE sample (column (5)), or (ii) the possibility that the shock time series estimates from VAR models, other statistical models, based on the narrative approach or financial market expectations represent different aspects of monetary policy shocks (columns (6) and (7)).

\subsection{Spillover estimates}

The third prediction from our hypothesis is that using shock estimates obtained from NK DSGE models in time-series regressions to estimate the effects of domestic monetary policy on the rest of the world produces large and implausibly similar spillover estimates for different spillover-sending economies. In order to test this prediction, we estimate the global output spillovers from domestic monetary policy shocks using the shock estimates in our database in local projections analogous to those in Equation (3). The sample we consider includes quarterly observations for 45 spillover-receiving economies spanning - depending on data availability - the time period from 1993q1 to 2007q2. For the dependent variable in the local projections we consider the logarithm of economies' real GDP. The control variables include domestic and trading-partner short-term interest rates, consumer-price inflation, and real GDP. ${ }^{12}$ We focus on the spillovers from monetary policy shocks for the US and the euro area. For each spillover-sending economy we extract the first principal component from all monetary policy shock time series estimates obtained from NK DSGE models which are available for the entire time period from 1993q1 to 2007q2, and use that principal component as shock measure in the estimation of the local projection.

The left-hand side panel in Figure 6 presents the averages of the estimates of the output spillovers from US and the euro area monetary policy across spillover-recipient economies. The estimates of the global output spillovers from monetary policy shocks in the US and the euro area are very similar. This finding is at odds with what we would expect given the differences in these two economies' systemic importance for trade and finance in the global economy (Bruno and Shin, 2015b,a; Gopinath, 2015; Casas et al., 2016). However, this finding is consistent with the third prediction from our hypothesis that the spillover estimates reflect

\footnotetext{
${ }^{12}$ For data on real GDP, consumer price inflation and short-term interest rates we draw on the GVAR Toolbox (see Smith and Galesi, 2011). The economies included are Argentina, Australia, Austria, Belgium, Brazil, Canada, Chile, China, Germany, Finland, France, Indonesia, India, Italy, Japan, Mexico, Malaysia, Netherlands, Norway, New Zealand, Peru, Philippines, Singapore, South Africa, South Korea, Spain, Sweden, Switzerland, Thailand, Turkey, UK, and the US. We add data obtained from Haver Analytics for Bolivia, Colombia, Croatia, Czech Republic, Denmark, Hungary, Ireland, Israel, Poland, Portugal, Paraguay, Romania, and Russia. The trade weights we use for the calculation of country-specific trading partner variables stem from the IMF Direction of Trade Statistics.
} 
the effects of a global or US monetary policy shock by which the domestic monetary policy shock estimates obtained from NK DSGE models for the euro area are contaminated.

Finally, also the third prediction from our hypothesis passes the placebo test: The righthand side panel in Figure 6 shows that when using the principal components of non-NK DSGE model shock time series estimates in the local projections the estimates of the global output spillovers from US monetary policy are notably larger than those from the euro area, consistent with the extraordinary role of the US in the global economy.

\section{Additional testable predictions, alternative explanations and robustness checks}

\subsection{Additional testable predictions}

\subsubsection{Role of banking integration}

The findings of research on financial integration prior to the global financial crisis allows us to refine the second prediction from our hypothesis. Specifically, the literature has emphasised the role of cross-border banking linkages for the international transmission of monetary policy in our sample period (see Goldberg, 2009; Cetorelli and Goldberg, 2012; Bruno and Shin, 2015b,a; Morais et al., 2015; Hale et al., 2016). We therefore replace the cross-country interaction between economies' gross foreign asset and liability position relative to GDP in Equation (4) by the interactions between portfolio, foreign direct and other investment relative to GDP. The results in column (2) in Table 9 suggest that contamination of monetary policy shock estimates obtained from NK DSGE models in our database by a common global component is indeed more severe for economies for which "other investment" - which includes bank loans - accounts for a larger share in their overall gross foreign asset and liability position. Of course, the category of "other investment" also includes items unrelated to bank loans, for example trade credit and advances, special drawing rights or currency and deposits. Therefore, in column (3) we consider the ratio of non-resident bank loans relative to GDP as an alternative and possibly more accurate measure of the importance of cross-border banking linkages. ${ }^{13}$ The results are consistent with the evidence on the importance of global banking integration for the international transmission of monetary policy prior to the global financial crisis.

\footnotetext{
${ }^{13}$ The data originally stem from the Bank for International Settlements and are consolidated in the World Bank's Financial Development and Structure Dataset (see Cihak et al., 2012).
} 


\subsubsection{Open-economy models}

Another prediction from our hypothesis is that NK DSGE models that feature an explicit open-economy dimension and/or frictions in international financial markets should be less prone to labelling foreign monetary policy shocks as domestic ones when confronted with the data. We test this prediction by entering dummy variables that equal unity in case at least one of the shock estimates stems from a model with open-economy elements - a multicountry model or a small open-economy model with or without financial spillover channelsinteracted with economies' susceptibility to financial spillovers in the regression of Equation (4). The results reported in Table 10 suggest that consistent with our baseline results the contamination of monetary policy shock estimates by a common global component - and thereby the cross-country correlations - is larger for economies which are more financially integrated overall and with the US bilaterally, but that this is mitigated if the modelling framework is a multi-country and/or small open-economy models with financial spillover channels. ${ }^{14}$

\subsubsection{Capital controls and exchange rate flexibility}

According to the Mundellian trilemma in international macroeconomics, economies are less susceptible to financial spillovers if they impose capital controls and/or let their exchange rate float. As a consequence, for a given degree of susceptibility to financial spillovers as measured by the stock of foreign assets and liabilities, we expect cross-country correlations between monetary policy shock estimates in our database to be lower for pairs of economies which impose capital controls and/or feature a higher degree of exchange rate flexibility. In column (2) in Table 11 we therefore report results from the regression of Equation (4) in which we include the products of economies' capital controls and their exchange rate flexibility as additional explanatory variables. ${ }^{15}$ Notice that this exercise is complicated by possible endogeneity between the strength of financial spillovers - and thereby the crosscountry correlation between monetary policy shock estimates - and the degree of capital controls as well as exchange rate flexibility: Economies which exhibit larger financial spillovers should also be those which impose tighter capital controls and feature a flexible exchange rate, precisely because they intend to shield their domestic financial markets from foreign disturbances. However, notice that this endogeneity bias is working against finding evidence for capital controls and flexible exchange rates reducing the cross-country correlations between

\footnotetext{
${ }^{14}$ We do not consider the observations on the cross-country correlations involving the monetary policy shock estimates from Vitek (2014), as these account for a very large share of the open-economy models in our database and as we want to preclude that the monetary policy shock estimates from one model might drive the results. However, the results are similar when these are included.

${ }^{15}$ We measure capital controls by the first principal component of the capital control/capital account openness indicators of Chinn and Ito (2006), Quinn and Toyoda (2008), as well as Fernandez et al. (2015). The index of exchange rate flexibility is taken from Ilzetzki et al. (2010).
} 
the monetary policy shock estimates in the regression of Equation (4). The results in column (3) indicate that cross-country correlations are indeed lower for - at least emerging marketeconomies which impose capital controls and/or feature flexible exchange rates, even if the relevant coefficient estimates are not large and/or estimated precisely, with $p$-values of around $11 \%$ and $18 \%$.

\subsection{Alternative explanations}

\subsubsection{Spillovers through trade}

One might argue that an alternative explanation for the positive cross-country correlation between the monetary policy shock estimates in our database could be the existence of spillovers through trade combined with common mistakes in assessing current and future economic conditions by central banks in real time. Specifically, suppose the Federal Reserve and non-US central banks, say the ECB and the Bank of Japan, all over-estimated real activity and inflation in the US in real time. As a result, the Federal Reserve would tighten monetary policy. Similarly, in order to mitigate the inflationary pressures from the expected stronger import demand from the US, the ECB and the Bank of Japan would also tighten their monetary policy. Ex post, the monetary policy tightening in the US, the euro area and Japan would be interpreted as contractionary monetary policy shocks by the econometrician. Importantly, these contractionary monetary policy shock estimates would be positively correlated across the euro area and Japan. In this scenario, the cross-country correlation between the monetary policy shock estimates arises due to trade integration between the US and the rest of the world. ${ }^{16}$ As trade and financial market integration in the data are strongly positively correlated, our baseline results in Table 8 might reflect omitted variable bias. However, our results are unchanged when we include measures of economies' overall trade integration and their bilateral trade integration with the US as additional explanatory variables (column (2) in Table 12).

\subsubsection{Bilateral common component}

One could also argue that the monetary policy shock estimates in our database are crosscountry correlated not because they contain a common global component, but because they share a bilateral component. In particular, the cross-country correlation between monetary policy shock estimates of two non-core economies could arise due to their bilateral trade and

\footnotetext{
${ }^{16} \mathrm{~A}$ variation of this argument is that the ECB and the Bank of Japan could actually loosen monetary policy in order to counter negative spillovers that follow from the tightening of monetary policy in the US. However, also under this scenario the monetary policy shocks of the euro area and Japan would be positively correlated ex post.
} 
financial integration in connection with similar arguments on common mis-assessments of future growth and inflation as in Section 4.2.1. However, our baseline results are unchanged if we include in the regression of Equation (4) measures of the strength of economies' bilateral trade and financial integration (columns (3) and (4) in Table 12). ${ }^{17}$

\subsubsection{Mis-specification of the Taylor-rule}

Another alternative explanation for the cross-country correlation between the monetary policy shock estimates in our database could be mis-specification of the Taylor-rule in estimated NK DSGE models. For example, economies might be subject to fear-of-floating even in the absence of a formal peg due to currency mismatches on their external balance sheet (see Calvo and Reinhart, 2002; Eichengreen et al., 2003). In such a setting, a depreciation of the domestic currency in response to a tightening of foreign monetary policy increases the homecurrency value of domestic firms' foreign liabilities denominated in foreign currency, which are - at least in emerging economies - often not matched by foreign-currency cash flows. In this case, foreign monetary policy would enter directly in the true domestic monetary policy reaction function; estimates of domestic monetary policy shocks would then be contaminated by foreign monetary policy shocks if the Taylor-rule specified in the NK DSGE model does not account for the dependence of domestic on foreign monetary policy. However, our baseline results are unchanged if we enter the interaction between economies' net short position in foreign currency as an additional explanatory variable (column (2) in Table 13). ${ }^{18}$ Crosscountry correlated monetary policy shock estimates could also arise if policymakers respond to variables that are correlated across countries, but this is not accounted for in the Taylorrules specified in the NK DSGE models. However, our baseline results are unchanged if we include a dummy variable indicating if at least one model features a Taylor-rule with open economy elements (such as the exchange rate, terms of trade or commodity prices) or variables which indicate susceptibility to global shocks such as the interaction of economies' share of fuel, ore and metal imports and exports in total imports and exports, or a dummy variable indicating if both economies are commodity exporters (see columns (3) to (5) in Table 13).

\subsubsection{Common global demand and supply shocks}

Finally, as discussed in Section 2, the lack of financial spillover channels in standard NK DSGE models might not only give rise to a global monetary policy component in domestic monetary policy shock estimates, but the common component might also consist of global demand and supply shocks. Under this hypothesis, we would expect the global component

\footnotetext{
${ }^{17}$ For bilateral trade the data are taken from the IMF's Direction of Trade Statistics and for bilateral financial integration from the IMF CPIS.

${ }^{18}$ The data on net foreign currency exposures are taken from Benetrix et al. (2015).
} 
in the domestic monetary policy shock estimates to be less strongly correlated for economies that are more heterogeneous regarding their susceptibility to spillovers from a range of foreign shocks. In order to test this competing hypothesis, we consider additional explanatory variables in the regression of Equation (4) that reflect the heterogeneity of economies along a number of dimensions. Specifically, we enter the absolute value of differences in economies' (i) overall trade integration with the rest of world, (ii) centrality in the global trade network, (iii) position and participation in global value chains, as well as their (iv) output, export and import structures. ${ }^{19}$ The results in Table 14 suggest our hypothesis that the common component in the monetary policy shock estimates is indeed mainly related to a global monetary policy shock.

\subsection{Robustness}

\subsubsection{Alternative samples}

It is worthwhile to slice our sample along several dimensions in order to explore the sensitivity of our results. First, one could argue that most of the NK DSGE monetary policy shock estimates in our database stem from parsimonious academic models that are meant to shed light on a particular transmission channel rather than to produce accurate estimates of the true monetary policy shocks. However, our results are unchanged if we restrict the sample to cross-country correlations between monetary policy shock estimates that are obtained from large and more sophisticated NK DSGE models used for policy advice at central banks and international organisations (column (2) in Table 15). In fact, the average cross-country correlation is equally large for monetary policy shock estimates that stem from structural models used at central banks and international organisations. ${ }^{20}$

Around a quarter of the cross-country correlations in our sample involves monetary policy shock estimates from the 40-country NK DSGE model of Vitek (2014). In order to ensure that our results are not driven by the monetary policy shock estimates from one particular

\footnotetext{
${ }^{19}$ The measure for the heterogeneity of economies' sectoral composition is the sum of the squared differences between two economies' output shares accounted for by a particular sector; for each sector, the squared difference is weighted by the share of that sector in global output. Global value chain participation and position are measures based on indirect and foreign value added. The data are taken from the World InputOutput Database (WIOD; Timmer et al., 2015). We use real GDP per capita and geographic variables in order to impute the observations on the measure of sectoral composition and global value chain properties for economies in our sample which are not available in the WIOD. Data on the centrality in the global trade network are taken from CEPII.

${ }^{20}$ The average cross-country correlation for monetary policy shock estimates from the NK DSGE models in our database that are used at central banks and international organisations is 0.094, while for the remaining NK DSGE models the average correlation is 0.051. This difference is mostly due to differences between the sets of country-pairs included in the baseline sample and the central bank/international organisations sample: The average cross-country correlation between the monetary policy shock estimates obtained from academic NK DSGE models is 0.093 when only those country-pairs for which we also have shock estimates from models used at central banks or international organisations are considered.
} 
model, we exclude the shocks from Vitek (2014) from the regression sample (column (3) in Table 15). The results suggest that the relationship between the cross-country correlations and economies' susceptibility to financial spillovers in our baseline results is not driven by the monetary policy shock estimates obtained from Vitek (2014).

Recall that in our baseline regression sample we only include economies for which we have at least three time series of monetary policy shock estimates and cross-country correlations which are calculated on the basis of at least 16 time series observations. However, our results do not change when we consider a sample which includes cross-country correlations of all NK DSGE monetary policy shock estimates in our database (column (4) in Table 15).

Not all of the monetary policy shock estimates in our database can be made publicly available due to confidentiality restrictions. However, our baseline results - and all specifications explored in this section - are robust to using only those monetary policy shock estimates which can be made publicly available (column (5)).

One might argue that we should not base our findings on monetary policy shock estimates obtained from studies which have not undergone peer review processes, as these might not (yet) meet the quality standards of the profession. The results reported in Table 16 indicate that our results are not driven by monetary policy shock estimates from non-peer-reviewed studies. Whether we consider only monetary policy shock estimates from studies that have been published in a journal or from studies which have been published in journals ranked above a certain "Keele"-list threshold, our baseline results are - in particular taking into account the substantial reduction in the sample - confirmed.

\subsubsection{Alternative model specifications}

In our baseline specification for the dependent variable we include cross-country correlations regardless of whether or not they are statistically significantly different from zero. However, our results are robust to setting the cross-country correlations $\rho_{\ell_{i}, m_{j}}$ on the left-hand side in Equation (4) which are not statistically significantly different from zero at the $10 \%$ significance level to zero (column (2) in Table 17).

One could also argue that our estimation could be inconsistent as our dependent variable is bounded between minus/plus unity, which is not accounted for by a linear regression. A common approach to circumvent this is to consider the logit transformation of the dependent variable. Our results are not sensitive to this variation of the regression specification (column (3) in Table 17). Moreover, our results are also robust to consider a Tobit regression, which accounts for the censored nature of the dependent variable explicitly (column (4)).

We also consider a more general but significantly more strongly parameterised specification 
with shock-country instead of country fixed effects in Equation (4) by estimating

$$
\rho_{\ell_{i}, m_{j}}=\alpha_{\ell_{i}}+\gamma_{m_{j}}+\boldsymbol{x}_{i j} \cdot \boldsymbol{\beta}+u_{\ell_{i}, m_{j}} .
$$

Column (5) in Table 17 documents that our results are unchanged for this alternative regression specification.

Robust (median) regression in column (6) in Table 17 that accounts for possible outliers delivers results which are unchanged relative to the baseline.

Our baseline measure of economies' susceptibility to financial spillovers - the product of their financial integration - might be too crude to adequately capture asymmetries in the contamination of domestic monetary policy shock estimates by a global component. Specifically, consider two country pairs. In the first country pair, both economies are moderately susceptible to financial spillovers from abroad. In the second country pair, one economy is highly susceptible to financial spillovers, while the second economy is almost completely insulated from global financial markets. While the product of economies' susceptibility to financial spillovers might be similar for both country pairs, we should expect different cross-country correlations between their monetary policy shock estimates. In particular, because in the second country pair one economy is essentially immune to financial spillovers in the data its monetary policy shock estimates should not be contaminated by a common global component; as a result, regardless of how severely contaminated the monetary policy shock estimates of the other economy are, the cross-country correlation should be zero. Put differently, while taking the product between economies' susceptibility to financial spillovers as explanatory variables does account for non-linearities, it might be that multiplication features too little curvature in order to capture consistently the relationship between economies' combined susceptibility to financial spillovers and the extent of mis-measurement of the monetary policy shocks. Therefore, as an alternative we consider the minimum of the values of the two economies' susceptibility to financial spillovers. The results in column (7) in Table 17 are unchanged compared to the baseline.

To the extent that we have monetary policy shock estimates from several NK DSGE models for a given economy in our database, the sample we consider for the regression of Equation (4) in the baseline in general includes a different number of observations on cross-country correlations for country pair $(i, j)$ than country pair $(m, \ell)$. One reason we choose this specification is that it implies a weighting of country-pair observations: A larger number of monetary policy shock estimates exists for economies which have been studied more intensively and for which data are more readily available; country pairs involving one or both of these economies receive a greater weight in our baseline regression. However, one might want to ensure that our results are not driven by such an implicit weighting. Therefore, we consider as dependent variable in Equation (4) observations of the cross-country correlations $\rho_{\ell_{i}, m_{j}}$ averaged 
within country pairs. However, at least for the overall susceptibility to financial spillovers, our results are robust to this alternative specification (column (8) in Table 17).

\subsubsection{US vs. euro area as core economy}

Finally, one may wonder if the common global component in domestic monetary policy shock estimates exclusively reflects a US component. In particular, for the many European economies in our sample the common component may also be driven by a euro area component. Column (2) in Table 18 reports results from a regression of Equation (4) in which we drop the cross-country correlations for country pairs that involve the euro area, in addition to those that involve the US; we also enter as additional explanatory variable the share of economies' overall financial integration accounted for by the euro area. Essentially, we hereby allow both the US and the euro area to represent core economies. The results for the coefficient estimate on economies' overall financial integration are unchanged. More importantly, the coefficient estimates of the shares of economies' overall financial integration accounted for by the US or the euro area are both positive. This finding is consistent with the notion that the common component in the monetary policy shock estimates contains both a US and a euro area component. While the coefficient estimates are not statistically significant at conventional significance levels, this finding nevertheless raises some doubts concerning the unique role of the US in driving a global financial cycle as well as the common component in the NK DSGE model monetary policy shock estimates in our database. Indeed, if we augment the regression of Equation (4) by a variable reflecting the share of economies' overall financial integration accounted for by the regional core - the euro area for European and the US for all other country pairs - then among the bilateral share variables only the coefficient estimate on this variable is statistically significant. Thus, the results are consistent with notion of the euro area being the driver of the European financial cycle, while the US that of the financial cycle of the rest of the world.

\section{Conclusion}

In this paper we provide evidence that is consistent with the hypothesis that many estimated NK DSGE models in the literature erroneously label foreign monetary policy shocks as domestic ones because they fail to adequately account for financial spillovers in the data. Specifically, we document that there is a statistically and economically significant, positive cross-country correlation between monetary policy shock estimates obtained from NK DSGE models. Also, the correlations are larger for pairs of economies which are more susceptible to financial spillovers in the data, as measured by their financial integration with the rest of the world and the US. Finally, we document that shock estimates from NK DSGE models imply 
large and implausibly similar estimates for the global output spillovers from monetary policy in a range of economies, such as the US and the euro area. The insights from this paper suggest that if NK DSGE models are to be used for policy advice, they should feature powerful financial spillover channels. Models without such elements are likely to provide misleading historical decompositions and inconsistent parameter estimates. 


\section{Acknowledgments}

We would like to thank for sharing their code and/or data (in alphabetical order) Pablo Aguilar, Shahzad Ahmad, Viktors Ajevskis, Harun Alp, Sami Alpanda, Martin Andreasen, Katrin Assenmacher-Wesche, Uluc Aysun, Oxana Babecka-Kucharcukova, Emanuele Bacchiocchi, Gregor Baeurle, Mehmet Balcilar, Alina Barnett, Mahdi Barakchian, Jean Barthelemy, Joselito Basilio, Daniel Beltran, Jonathan Benchimon, Konstantins Benkovskis, Alon Binyamini, Hilde Bjørnland, Martin Bodenstein, Michal Brzoza-Brzezina, Daniel Buncic, Matthias Burgert, Petre Caraiani, Julio Carrillo, Fabia de Carvalho, Michele Ca'Zorzi, Ambrogio CesaBianchi, Jaqian Chen, Xiaoshan Chen, Kai Christoffel, Hess Chung, Edda Claus, Francesco Columba, Mihai Copaciu, Vesna Corbo, Tobias Cwik, Vincent Dadam, Riccardo DiCecio, Taeyoung Doh, Mardi Dungey, Michael Ehrmann, Adam Elbourne, Selim Elekdag, Angelo Fasolo, Daniel Felcser, Martin Feldkircher, Daria Finocchario, Jorge Fornero, Matteo Fragetta, Takuji Fueki, Alain Gabler, Vasco Gabriel, Luca Gambetti, Carlos Garcia, Andrea Gazzani, Javier Garcia-Cicco, Paolo Gelain, Andrea Gerali, Karsten Gerdrup, Taniya Ghosh, Federico Giri, Caio Goncalves, Wildo Gonzalez, Denis Gorea, Rangan Gupta, Yuong Ha, Adnan Haider, Richard Harrison, Klemens Hauzenberger, Reinhold Henlein, Yasuo Hirose, Mathias Hoffmann, Nikolay Hristov, Patrick Huertgen, Matteo Iacoviello, Punnoose Jacob, Nils Jannsen, Jiadan Jiang, Monika Junicke, Alain Kabundi, Sohei Kaihatsu, Gunes Kamber, Muneesh Kapur, Peter Karadi, Mitsuru Katagiri, Tae Bong Kim, Markus Kirchner, Bohdan Klos, Lena Körber, Jenny Körner, Dimitris Korobilis, Kevin Kotze, Michael Kühl, Abhishek Kumar, Romain Lafarguette, Sean Langcakes, Stefan Laseen, Jungick Lee, Kirdan Lees, Stefan Leist, Fernando Linardi, Marco Lo Duca, Matteo Luciani, Lena Malesevic Perovic, Shuyun May Li, Krzysztof Makarski, Martin Mandler, Pym Manopimoke, Bruno Martins, Renee McKibbin, Rossana Merola, Fabio Milani, Stephen Millard, Silvia MirandaAgrippino, Benoit Mojon, Konstantinos Mouratidis, Haroon Mumtaz, Jouchi Nakajima, Ruthira Naraidoo, Jean-Marc Natal, Eliphas Ndou, Daniel Nemec, Matthias Neuenkirch, Eric Ng, Anh Nguyen, Kris Nimark, Victoria Nuguer, Alberto Ortiz, Oguzhan Özcelebi, Alessia Paccagnini, Michael Paetz, Matthias Paustian, Jesper Pedersen, Tao Peng, Napat Phongluangtham, Massimiliano Pisani, Alexey Ponomarenko, Raluca Pop, Ioannis Pragidis, Dominic Quint, Mala Raghavan, Tovonony Razafindrabe, Daniel Rees, Muhammad Rehman, Sigal Ribon, Tim Robinson, Ørjan Robstad, Diego Rodriguez, Norberto Rodriguez Nino, Barbara Rudolph, Yuliya Rychalovska, Jakub Rysanek, Kouji Takahashi, Konstantinos Theodoridis, Dawid Trzeciakiewicz, Tomohiro Tsugura, Stanislav Tvrz, Jean-Guillaume Sahuc, Luca Sala, Frank Schorfheide, Roman Semko, Andrei Shulgin, Martin Slanicay, Juste Some, Rudi Steinbach, Grzegorz Szafranski, Surach Tanboon, Jaromir Tonner, Lenno Uusküla, Joab Dan Valdivia Coria, Osvald Vasicek, Gauthier Vermandel, Fabio Verona, Alejandro Vicondoa, Stefania Villa, Francis Vitek, Balazs Vonnak, Graham Voss, Marija Vukotic, Ben Zhe Wang, Raf Wouters, Bo Yang, Pawel Zabzcyk, Francesco Zanetti, Juraj Zeman, Xuan Zhang, Jasmine Zheng, Peng Zhou and Sarah Zubairy.

Moreover, we would like to thank colleagues at Bank of Canada, Bank of Finland, Bank of Israel, Bank of Italy, Bank of Japan, Bank of Korea, Bank of Mexico, Bank of Russia, Bank of Thailand, Bundesbank, Central Bank of Brazil, Central Bank of Chile, Central Bank of Colombia, Central Bank of Iceland, Czech National Bank, European Central Bank, Federal Reserve Board, International Monetary Fund, National Bank of Poland, National Bank of Romania, Norges Bank, Reserve Bank of South Africa, Reserve Bank of Australia, Reserve 
Bank of New Zealand, Sveriges Riksbank, and Swiss National Bank, who helped the colleagues listed above to make the data available to us.

We would also wish to thank for their comments Michael Binder, Alberto Ortiz Bolanos, Benjamin Born, Giancarlo Corsetti, Luca Dedola, Jesus Fernandez-Villaverde, Wouter den Haan, Jordi Gali, Robert Kollmann, Falk Mazelis, Paul McNelis, Luca Onorante, Gert Peersman, Bruce Preston, Giorgio Primiceri, Stephanie Schmitt-Grohe, Livio Stracca, Georg Strasser, Roland Straub, Cedric Tille, and Stanislav Tvrz.

Finally, we would also like to thank conference and seminar participants at European Central Bank, Asian Development Bank, Center for Latin American Monetary Studies, the Bank of England-ECB-IMF workshop on "Global Spillovers: How much do we really know?", the CEPR-IMFS Conference "New Methods for Macroeconomic Modelling, Model Comparison and Policy Analysis", the $6^{\text {th }}$ Bangko Sentral ng Pilipinas International Research Conference on "Revisiting Macro-financial Linkages", the $6^{\text {th }}$ IWH/INFER Workshop on "(Ending) Unconventional Monetary Policy", the National Bank of Slovakia conference on "Monetary Policy Challenges from a Small Country Perspective", the $20^{\text {th }}$ International Conference on Macroeconomic Analysis and International Finance, the $31^{\text {st }}$ Irish Economic Association Annual Conference, the $21^{\text {st }}$ Spring Meeting of Young Economists, the $9^{\text {th }}$ FIW Research Conference on International Economics, and the 2016 Ioannina Meeting on Applied Economics and Finance. 


\section{References}

Adame, F., Carrillo, J., Roldan-Pena, J., Zerecero, M., 2016. Financial Considerations in a Small Open Economy Model for Mexico. mimeo.

Adolfson, M., Laséen, S., Christiano, L., Trabandt, M., Walentin, K., 2013. RAMSES II Model Description. Sveriges Riksbank Occasional Paper 12.

Adolfson, M., Laséen, S., Lindé, J., Svensson, L. E. O., 2011. Optimal monetary policy in an operational medium-sized DSGE model. Board of Governors of the Federal Reserve System International Finance Discussion Papers 1023.

Aguilar, P., Vzquez, J., 2015. The Role of Term Structure in an Estimated DSGE Model with Learning. Université Catholique de Louvain Institut de Recherches Economiques et Sociales Discussion Paper 2015007.

Ahmad, S., 2017. Comparison of Forecasting Performance of DSGE And VAR Models: The Case of Pakistan. mimeo.

Ahmed, W., Jahanzeb Malik, M., Rehman, M., 2014. Quarterly Bayesian DSGE Model of Pakistan Economy with Informality. State Bank of Pakistan Working Paper 68.

Ajevskis, V., Vitola, K., 2011. Fixed Exchange Rate Versus Inflation Targeting: Evidence from DSGE Modelling. Latvijas Banka Working Paper 2011/02.

Albonico, A., Paccagnini, A., Tirelli, P., 2014. Estimating a DSGE Model with Limited Asset Market Participation for the Euro Area. University of Milano-Bicocca Department of Economics Working Papers 286.

Albonico, A., Paccagnini, A., Tirelli, P., forthcoming. In Search of the Euro Area Fiscal Stance. Journal of Empirical Finance.

Alp, H., Elekdag, S., 2013. The Role of Monetary Policy in Turkey During the Global Financial Crisis. In: Braude, J., Eckstein, Z., Fischer, S., Flug, K. (Eds.), The Great Recession: Lessons for Central Bankers. MIT Press, pp. 51-80.

Alp, H., Elekdag, S., Lall, S., 2012. Did Korean Monetary Policy Help Soften the Impact of the Global Financial Crisis of 2008-2009? IMF Working Paper 12/5.

Alpanda, S., Aysun, U., 2014. International Transmission of Financial Shocks in an Estimated DSGE Model. Journal of International Money and Finance 47 (C), 21-55.

Andreasen, M., 2012. An Estimated DSGE Model: Explaining Variation in Nominal Term Premia, Real Term Premia, and Inflation Risk Premia. European Economic Review 56 (8), 1656-1674.

Andrle, M., 2014. Estimating Structural Shocks with DSGE Models. mimeo.

Argov, E., Barnea, E., Binyamini, A., Borenstein, E., Elkayam, D., Rozenshtrom, I., 2012. MOISE: A DSGE Model for the Israeli Economy. Bank of Israel Discussion Paper 2012.06.

Assenmacher-Wesche, K., 2008. Modeling Monetary Transmission in Switzerland with a Structural Cointegrated VAR Model. Swiss Journal of Economics and Statistics (SJES) 144, 197-246. 
Avouyi-Dovi, S., Sahuc, J.-G., 2016. On the Sources of Macroeconomic Stability in the Euro Area. European Economic Review 83 (C), 40-63.

Azoulay, E., Ribon, S., 2010. A Basic Structural VAR of Monetary Policy in Israel Using Monthly Frequency Data. Bank of Israel Discussion Paper (2010.04).

Babecka Kucharcukova, O., Claeys, P., Vasicek, B., 2016. Spillover of the ECB's Monetary Policy Outside the Euro Area: How Different is Conventional From Unconventional Policy? Journal of Policy Modeling 38 (2), 199-225.

Bacchiocchi, E., Castelnuovo, E., Fanelli, L., forthcoming. Gimme a Break! Identification and Estimation of the Macroeconomic Effects of Monetary Policy Shocks in the US. Macroeconomic Dynamics.

Bacchiocchi, E., Fanelli, L., 2015. Identification in Structural Vector Autoregressive Models with Structural Changes, with an Application to US Monetary Policy. Oxford Bulletin of Economics and Statistics 77 (6), 761-779.

Bagliano, F., Favero, C., 1998. Measuring Monetary Policy with VAR Models: An Evaluation. European Economic Review 42 (6), 1069-1112.

Banerjee, R., Devereux, M., Lombardo, G., 2016. Self-Oriented Monetary Policy, Global Financial Markets and Excess Volatility of International Capital Flows. Journal of International Money and Finance 68, 275-297.

Barakchian, M., Crowe, C., 2013. Monetary Policy Matters: Evidence from New Shocks Data. Journal of Monetary Economics 60 (8), 950-966.

Baranowski, P., Gorajski, M., Malaczewski, M., Szafranski, G., 2016. Inflation in Poland under State-dependent Pricing. Ekonomicky Casopis/Economic Journal 10 (64), 937-957.

Barigozzi, M., Conti, A. M., Luciani, M., October 2014. Do Euro Area Countries Respond Asymmetrically to the Common Monetary Policy? Oxford Bulletin of Economics and Statistics 76 (5), 693-714.

Barnett, W., Bhadury, S., Ghosh, T., 2015. An SVAR Approach to Evaluation of Monetary Policy in India: Solution to the Exchange Rate Puzzles in an Open Economy 201503.

Bekaert, G., Hoerova, M., Lo Duca, M., 2013. Risk, Uncertainty and Monetary Policy. Journal of Monetary Economics 60 (7), 771-788.

Beltran, D., Draper, D., 2008. Estimating the Parameters of a Small Open-Economy DSGE Model: Identifiability and Inferential Validity. International Finance Discussion Papers 955.

Benchimol, J., 2016. Money and Monetary Policy in Israel During the Last Decade. Journal of Policy Modeling 38 (1), 103-124.

Benchimol, J., Fourcans, A., forthcoming. Money and Monetary Policy in the Eurozone: An Empirical Analysis During Crises. Macroeconomic Dynamics.

Benetrix, A., Lane, P., Shambaugh, J., 2015. International Currency Exposures, Valuation Effects and the Global Financial Crisis. Journal of International Economics 96 (S1), 98-209. 
Benkovskis, K., Bessonovs, A., Feldkircher, M., Wörz, J., 2011. The Transmission of Euro Area Monetary Shocks to the Czech Republic, Poland and Hungary: Evidence from a FAVAR Model. Focus on European Economic Integration (3), 8-36.

Bernanke, B., 1986. Alternative Explanations of the Money-income Correlation. CarnegieRochester Conference Series on Public Policy 25 (1), 49-99.

Bernanke, B., Boivin, J., Eliasz, P., 2005. Measuring the Effects of Monetary Policy: A FactorAugmented Vector Autoregressive (FAVAR) Approach. Quarterly Journal of Economics $120(1), 387-422$.

Bernanke, B., Kuttner, K., 2005. What Explains the Stock Market's Reaction to Federal Reserve Policy? Journal of Finance 60 (3), 1221-1257.

Bernanke, B., Mihov, I., 1998. Measuring Monetary Policy. The Quarterly Journal of Economics 113 (3), 869-902.

Bhattaraia, K., Trzeciakiewiczb, D., 2017. Macroeconomic Impacts of Fiscal Policy Shocks in the UK: A DSGE Analysis. Economic Modelling 61, 321-338.

Binder, M., Chen, Q., Zhang, X., 2010. On the Effects of Monetary Policy Shocks on Exchange Rates. CESifo Working Paper 3162.

Bjørnland, H., Jacobsen, D., 2010. The Role of House Prices in the Monetary Policy Transmission Mechanism in Small Open Economies. Journal of Financial Stability 6 (4), 218-229.

Blanchard, O., 2016. Do DSGE Models Have a Future? PIIE Policy Brief PB16-11.

Boivin, J., Giannoni, M., Mojon, B., December 2009. How Has the Euro Changed the Monetary Transmission Mechanism? In: NBER Macroeconomics Annual 2008, Volume 23. NBER Chapters. National Bureau of Economic Research, pp. 77-125.

Bong, K. S., Doh, T., Park, W. Y., 2016. Yield Curve and Monetary Policy Expectations in Small Open Economies. Federal Reserve Bank of Kansas City Working Paper 14-13.

Brayton, F., Laubach, T., Reifschneider, D., 2014. The FRB/US Model: A Tool for Macroeconomic Policy Analysis. FEDS Notes 2014-11-21, Board of Governors of the Federal Reserve System.

Breuss, F., Fornero, J., 2009. An Estimated DSGE Model of Austria, the Euro Area and the US: Some Welfare Implications of EMU. FIW Working Paper 034.

Bruno, V., Shin, H. S., 2015a. Capital Flows and the Risk-taking Channel of Monetary Policy. Journal of Monetary Economics 71 (C), 119-132.

Bruno, V., Shin, H. S., 2015b. Cross-Border Banking and Global Liquidity. Review of Economic Studies 82 (2), 535-564.

Brzoza-Brzezina, M., Makarski, K., 2011. Credit crunch in a small open economy. Journal of International Money and Finance 30 (7), 1406-1428.

Burgess, S., Fernandez-Corugedo, E., Groth, C., Harrison, R., Monti, F., Theodoridis, K., Waldron, M., 2013. The Bank of England's Forecasting Platform: COMPASS, MAPS, EASE and the Suite of Models. Bank of England Working Paper 471. 
Burlon, L., Notarpietro, A., Pisani, M., 2016. Forecasting for a Large-scale Open-economy DSGE Model for the Euro Area. mimeo.

Caglayan, M., Kandemir Kocaaslan, O., Mouratidis, K., 2016. Financial Depth and the Asymmetric Impact of Monetary Policy. Oxford Bulletin of Economics and Statistics.

Calvo, G., Reinhart, C., 2002. Fear of Floating. The Quarterly Journal of Economics 117 (2), 379-408.

Canova, F., 2005. The Transmission of US Shocks to Latin America. Journal of Applied Econometrics 20 (2), 229-251.

Carabenciov, I., Ermolaev, I., Freedman, C., Juillard, M., Kamenik, O., Korshunov, D., Laxton, D., Laxton, J., 2008. A Small Quarterly Multi-Country Projection Model with Financial-Real Linkages and Oil Prices. IMF Working Paper 08/208.

Caraiani, P., 2013. Comparing Monetary Policy Rules in CEE Economies: A Bayesian Approach. Economic Modelling 32 (C), 233-246.

Carlstrom, C., Fuerst, T., Ortiz, A., Paustian, M., 2014. Estimating Contract Indexation in a Financial Accelerator Model. Journal of Economic Dynamics and Control 46 (C), 130-149.

Casas, C., Diez, F., Gopinath, G., Gourinchas, P.-O., 2016. Dominant Currency Paradigm. NBER Working Papers 22943.

Ca'Zorzi, M., Kolasa, M., Rubaszek, M., 2016. Exchange Rate Forecasting with DSGE Models. ECB Working Paper 1905.

Cesa-Bianchi, A., Thwaites, G., Vicondoa, A., 2016. Monetary Policy Transmission in an Open Economy: New Data and Evidence from the United Kingdom. mimeo.

Cetorelli, N., Goldberg, L., 2012. Banking Globalization and Monetary Transmission. Journal of Finance 67 (5), 1811-1843.

Chen, J., Columba, F., 2016. Macroprudential and Monetary Policy Interactions in a DSGE Model for Sweden. IMF Working Paper 16/74.

Chen, Q., Filardo, A., He, D., Zhu, F., 2016. Financial Crisis, US Unconventional Monetary Policy and International Spillovers. Journal of International Money and Finance 67 (C), 62-81.

Chen, X., Macdonald, R., 2012. Realized and Optimal Monetary Policy Rules in an Estimated MarkovSwitching DSGE Model of the United Kingdom. Journal of Money, Credit and Banking 44 (6), 1091-1116.

Chin, M., Filippeli, T., Theodoridis, K., 2015. Cross-country Co-movement in Long-term Interest Rates: A DSGE Approach. Bank of England Working Paper 530.

Chinn, M., Ito, H., 2006. What Matters for Financial Development? Capital Controls, Institutions, and Interactions. Journal of Development Economics 81 (1), 163-192.

Christiano, L., Eichenbaum, M., Evans, C., 1999. Monetary Policy Shocks: What Have We Learned and to What End? In: Taylor, J. B., Woodford, M. (Eds.), Handbook of Monetary Economics. Amsterdam: Elsevier Science, pp. 65-148. 
Christiano, L. J., Eichenbaum, M., Evans, C. L., 2005. Nominal Rigidities and the Dynamic Effects of a Shock to Monetary Policy. Journal of Political Economy 113 (1), 1-45.

Christiano, L. J., Motto, R., Rostagno, M., 2014. Risk Shocks. American Economic Review 104 (1), 27-65.

Christoffel, K., Coenen, G., Warne, A., 2008. The New Area-Wide Model of the Euro Area: A Micro-Founded Open-Economy Model for Forecasting and Policy Analysis. ECB Working Paper 0944.

Chung, H., Kiley, M., Laforte, J.-P., 2010. Documentation of the Estimated, Dynamic, Optimization-based (EDO) model of the U.S. economy: 2010 Version. Board of Governors of the Federal Reserve System Finance and Economics Discussion Series 2010-29.

Cihak, M., Demirguc-Kunt, A., Feyen, E., Levine, R., 2012. Benchmarking Financial Systems Around the World. World Bank Policy Research Working Paper 6175.

Claus, E., Claus, I., Krippner, L., 2016. Monetary Policy Spillovers across the Pacific when Interests are at the Zero Lower Bound. Asian Economic Papers 15 (3), 1-27.

Claus, E., Dungey, M., 2012. US Monetary Policy Surprises: Identification with Shifts and Rotations in the Term Structure. Journal of Money, Credit and Banking 44 (7), 1443-1453.

Claus, E., Dungey, M., 2016. Can Monetary Policy Surprises Affect the Term Structure? Journal of Macroeconomics 47, 68-83.

Cloyne, J., Hürtgen, P., forthcoming. The Macroeconomic Effects of Monetary Policy: A New Measure for the United Kingdom. American Economic Journal: Macroeconomics.

Coenen, G., Wieland, V., 2002. Inflation Dynamics and International Linkages: A Model of the United States, the Euro Area and Japan. ECB Working Paper 0181.

Copaciu, M., Nalban, V., Bulete, C., 2016. R.E.M. 2.0 - A DSGE Model with Partial Euroization Estimated for Romania. National Bank of Romania Occasional Papers 21.

Cuche-Curti, N., Dellas, H., Natal, J.-M., 2009. A Dynamic Stochastic General Equilibrium Model for Switzerland. Swiss National Bank Economic Studies 2009-05.

Dadam, V., Viegi, N., 2014. Labour Market and Monetary Policy in South Africa. In: Fourteen Years of Inflation Targeting in South Africa and the Challenge of a Changing Mandate. South African Reserve Bank, pp. 113-137.

Dai, L., Minford, P., Zhou, P., 2015. A DSGE Model of China. Applied Economics 47 (59), 6438-6460.

de Carvalho, F. A., Castro, M. R., May 2015. Foreign Capital Flows, Credit Growth and Macroprudential Policy in a DSGE Model with Traditional and Matter-of-Fact Financial Frictions. Central Bank of Brazil, Research Department Working Paper Series (387).

de Carvalho, F. A., Castro, M. R., Costa, S. M. A., 2014. Traditional and Matter-of-fact Financial Frictions in a DSGE Model for Brazil: The Role of Macroprudential Instruments and Monetary Policy. 
de Carvalho, F. A., Valli, M., Apr. 2011. Fiscal Policy in Brazil through the Lens of an Estimated DSGE Model. Central Bank of Brazil, Research Department Working Paper (240).

Dedola, L., Lombardo, G., 2012. Financial Frictions, Financial Integration and the International Propagation of Shocks. Economic Policy 27 (70), 319-359.

Dedola, L., Rivolta, G., Stracca, L., 2015. When the Fed Sneezes, Who Gets a Cold? mimeo.

Devereux, M., Yetman, J., 2010. Leverage Constraints and the International Transmission of Shocks. Journal of Money, Credit and Banking 42 (s1), 71-105.

di Giovanni, J., Shambaugh, J., 2008. The Impact of Foreign Interest Rates on the Economy: The Role of the Exchange Rate Regime. Journal of International Economics 74 (2), 341361.

DiCecio, R., Nelson, E., November 2010. Euro Membership as a U.K. Monetary Policy Option: Results from a Structural Model. In: Europe and the Euro. NBER Chapters. National Bureau of Economic Research, Inc, pp. 415-439.

Dorich, J., Johnston, M., Mendes, R., Murchison, S., Zhang, Y., 2013. ToTEM II: An Updated Version of the Bank of Canada's Quarterly Projection Model. Technical Reports 100, Bank of Canada.

Drygalla, A., 2015. Switching to Exchange Rate Flexibility? The Case of Central and Eastern European Inflation Targeters. FIW Working Paper 139.

Dungey, M., Osborn, D., 2014. Modelling Large Open Economies With International Linkages: The Usa And Euro Area. Journal of Applied Econometrics 29 (3), 377-393.

Dungey, M., Osborn, D., Raghavan, M., 2014. International Transmissions to Australia: The Roles of the USA and Euro Area. The Economic Record 90 (291), 421-446.

Ehrmann, M., Fratzscher, M., 2003. Monetary Policy Announcements and Money Markets: A Transatlantic Perspective. International Finance 6 (3), 309-28.

Ehrmann, M., Fratzscher, M., 2005. Equal Size, Equal Role? Interest Rate Interdependence Between the Euro Area and the United States. Economic Journal 115 (506), 928-948.

Ehrmann, M., Fratzscher, M., 2009. Global Financial Transmission of Monetary Policy Shocks. Oxford Bulletin of Economics and Statistics 71 (6), 739-759.

Ehrmann, M., Fratzscher, M., Rigobon, R., 2011. Stocks, Bonds, Money Markets and Exchange Rates: Measuring International Financial Transmission. Journal of Applied Econometrics 26 (6), 948-974.

Eichengreen, B., Hausmann, R., Panizza, U., 2003. Le péché originel: Le calvaire, le mystère et le chemin de la rédemption. L'Actualité Economique 79 (4), 419-455.

Ellis, C., Mumtaz, H., Zabczyk, P., 05 2014. What Lies Beneath? A Time-varying FAVAR Model for the UK Transmission Mechanism. Economic Journal 124 (576), 668-699.

Errit, G., Uusküla, L., 2014. Euro Area Monetary Policy Transmission in Estonia. Baltic Journal of Economics 14 (1-2), 55-77. 
Faccini, R., Millard, S., Zanetti, F., 2013. Wage Rigidities in an Estimated Dynamic, Stochastic, General Equilibrium Model of the UK Labour Market. The Manchester School 81, 66-99.

Felcser, D., Vonnak, B., 2014. Carry Trade, Uncovered Interest Parity and Monetary Policy. MNB Working Papers 2014/3.

Feldkircher, M., Huber, F., 2015. The International Transmission of US Structural Shocks: Evidence from Global Vector Autoregressions. European Economic Review 81, 167-188.

Feldkircher, M., Huber, F., 2016. The International Transmission of US Shocks: Evidence from Bayesian Global Vector Autoregressions. European Economic Review 81 (C), 167-188.

Fernandez, A., Klein, M., Rebucci, A., Schindler, M., Uribe, M., 2015. Capital Control Measures: A New Dataset. NBER Working Paper 20970.

Feve, P., Sahuc, J.-G., 2016. In Search of the Transmission Mechanism of Fiscal Policy in the Euro Area. Journal of Applied Econometrics.

Forni, M., Gambetti, L., 2010. The Dynamic Effects of Monetary Policy: A Structural Factor Model Approach. Journal of Monetary Economics 57 (2), 203-216.

Fragetta, M., Melina, G., 2013. Identification of Monetary Policy in SVAR Models: A Dataoriented Perspective. Empirical Economics 45 (2), 831-844.

Fueki, T., Fukunaga, I., Ichiue, H., Shirota, T., 2016. Measuring Potential Growth with an Estimated DSGE Model of Japan's Economy. International Journal of Central Banking $12(1), 1-32$.

Furlanetto, F., Gelain, P., Sanjani, M., 2014. Output Gap in Presence of Financial Frictions and Monetary Policy Trade-offs. IMF Working Paper 14/128.

Gabriel, V., Levine, P., , Yang, B., 2016. An Estimated DSGE Open-Economy Model of the Indian Economy with Financial Frictions. In: Ghate, C., Kletzer, K. (Eds.), Monetary Policy in India: A Modern Macroeconomic Perspective. Springer.

Gabriel, V., Levine, P., Pearlman, J., Yang, B., 2012. An Estimated DSGE Model of the Indian Economy. In: Ghate, C. (Ed.), Oxford Handbook of the Indian Economy. Oxford University Press.

Gadatsch, N., Hauzenberger, K., Stähler, N., 2016. Fiscal Policy During the Crisis: A Look on Germany and the Euro Area with GEAR. Economic Modelling 52 (PB), 997-1016.

Galí, J., Gambetti, L., 2015. The Effects of Monetary Policy on Stock Market Bubbles: Some Evidence. American Economic Journal: Macroeconomics 7 (1), 233-57.

Gallic, E., Vermandel, G., 2016. Climate Shocks and Business Cycles. mimeo.

Garcia, C., Gonzalez, W., 2014. Why Does Monetary Policy Respond to the Real Exchange Rate in Small Open Economies? A Bayesian Perspective. Empirical Economics 46 (3), 789-825.

Gazzani, A., Vicondoa, A., 2016. Proxy-SVAR as a Bridge between Mixed Frequencies. mimeo. 
Gelain, P., 2010. The External Finance Premium in the Euro Area: A Dynamic Stochastic General Equilibrium Analysis. The North American Journal of Economics and Finance 21 (1), 49-71.

Georgiadis, G., 2016. Determinants of Global Spillovers from US Monetary Policy. Journal of International Money and Finance 67, 41-61.

Gerali, A., Neri, S., Sessa, L., Signoretti, F. M., 2010. Credit and Banking in a DSGE Model of the Euro Area. Journal of Money, Credit and Banking 42 (1), 107-141.

Gerdrup, K., Motzfeldt Kravik, E., Saterhagen Paulsen, K., 2017. Documentation of NEMO - Norges Bank's Core Model for Monetary Policy Analysis and Forecasting. mimeo.

Gertler, M., Karadi, P., 2011. A Model of Unconventional Monetary Policy. Journal of Monetary Economics 58 (1), 17-34.

Gertler, M., Karadi, P., 2015. Monetary Policy Surprises, Credit Costs, and Economic Activity. American Economic Journal: Macroeconomics 7 (1), 44-76.

Gertler, M., Sala, L., Trigari, A., 2008. An Estimated Monetary DSGE Model with Unemployment and Staggered Nominal Wage Bargaining. Journal of Money, Credit and Banking 40 (8), 1713-1764.

Gervais, O., Gosselin, M.-A., 2014. Analyzing and Forecasting the Canadian Economy through the LENS Model. Technical Reports 102, Bank of Canada.

Ghosh, A., Qureshi, M., Kim, J., Zalduendo, J., 2014. Surges. Journal of International Economics 92 (2), 266-285.

Giri, F., 2014. Does Interbank Market Matter for Business Cycle Fluctuation? An Estimated DSGE Model with Financial Frictions for the Euro Area. Universita' Politecnica delle Marche Dipartimento di Scienze Economiche e Sociali Working Paper 398.

Goldberg, L., 2009. Understanding Banking Sector Globalization. IMF Staff Papers 56 (1), 171-197.

Gonzalez, A., Hamann, F., Rodriguez, D., 2015. Macroprudential Policies in a Commodity Exporting Economy. BIS Working Paper 506.

Gopinath, G., 2015. The International Price System. NBER Working Papers 21646.

Goyal, A., Kumar, A., 2016. A DSGE Model-Based Analysis of The Indian Slowdown. mimeo.

Grabek, G., Klos, B., 2013. Unemployment in the Estimated New Keynesian SoePL-2012 DSGE Model. National Bank of Poland Working Paper 144.

Gregor Bäurle, M. G., Känzig, D., 2016. Time-Varying Effects of Oil Supply Shocks on the US Economy. mimeo.

Gupta, R., Steinbach, R., 2013. A DSGE-VAR Model for Forecasting Key South African Macroeconomic Variables. Economic Modelling 33, 19-33.

Hale, G., Kapan, T., Minoiu, C., 2016. Crisis Transmission in the Global Banking Network. IMF Working Paper 16/91. 
Harrison, R., Oomen, O., 2010. Evaluating and Estimating a DSGE Model for the United Kingdom. Bank of England Working Paper 380.

Heinlein, R., Krolzig, H.-M., 2013. Monetary Policy and Exchange Rates: A Balanced TwoCountry Cointegrated VAR Model Approach 1321.

Herber, P., Nemec, D., 2009. Estimating Output Gap in the Czech Republic: DSGE Approach. Mathematical Methods in Economics 8, 117-124.

Herber, P., Nemec, D., 2012. Investigating Structural Differences of the Czech Economy: Does Asymmetry of Shocks Matter? Bulletin of the Czech Econometric Society 19 (29).

Hernan Hernandez, M., Ortiz Bolanos, A., 2016. Monetary and Fiscal Policies in Latin America: Evidence from an Estimated DSGE Model. mimeo.

Hirose, Y., 2014. An Estimated DSGE Model with a Deflation Steady State. CAMA Working Paper 2014-52.

Hristov, N., 2016. The Ifo DSGE Model for the German Economy. Ifo Working Paper 210.

Iacoviello, M., Minetti, R., 2006. International Business Cycles with Domestic and Foreign Lenders. Journal of Monetary Economics 53 (8), 2267-2282.

Iacoviello, M., Neri, S., 2010. Housing Market Spillovers: Evidence from an Estimated DSGE Model. American Economic Journal: Macroeconomics 2 (2), 125-64.

Ilzetzki, E., Reinhart, C., Rogoff, K., 2010. Exchange Rate Arrangements Entering the 21st Century: Which Anchor Will Hold? mimeo, London School of Economics.

IMF, 2017. Are Countries Losing Control of Domestic Financial Conditions? In: Global Financial Stability Report, Chpt. 3.

Ito, H., 2014. Monetary Policy in Asia and the Pacific in the Post, Post-Crisis Era. mimeo.

Jacob, P., Munro, A., 2016. A Macroprudential Stable Funding Requirement and Monetary Policy in a Small Open Economy DP2016/04.

Jannsen, N., Klein, M., 2011. The International Transmission of Euro Area Monetary Policy Shocks. Kiel Institute for the World Economy Working Paper 1718.

Jiang, J., Kim, D., 2013. Is China's Monetary Policy Effective? Evaluating the VAR Evidence. China Economic Policy Review 2 (2), 1-21.

Jorda, O., 2005. Estimation and Inference of Impulse Responses by Local Projections. American Economic Review 95 (1), 161-182.

Junicke, M., 2015. Trend inflation and monetary policy in Eastern Europe. mimeo.

Justiniano, A., Preston, B., 2010. Can Structural Small Open-economy Models Account for the Influence of Foreign Disturbances? Journal of International Economics 81 (1), 61-74.

Kaihatsu, S., Kurozumi, T., 2014. Sources of Business Fluctuations: Financial or Technology Shocks? Review of Economic Dynamics 17 (2), 224-242. 
Kamber, G., McDonald, C., Sander, N., Theodoridis, K., 2016. Modelling the Business Cycle of a Small Open Economy: The Reserve Bank of New Zealand's DSGE Model. Economic Modelling 59, 546-569.

Kamber, G., Millard, S., December 2012. Using Estimated Models to Assess Nominal and Real Rigidities in the United Kingdom. International Journal of Central Banking 8 (4), 97-119.

Kamber, G., Smith, C., Thoenissen, C., 2015. Financial Frictions and The role of Investmentspecific Technology Shocks in the Business Cycle. Economic Modelling 51, 571-582.

Kapur, M., Behera, H., 2012. Monetary Transmission Mechanism in India: A Quarterly Model. mimeo.

Katagiri, M., Takahashi, K., 2016. The Effects of Unconventional Monetary Policy in an Open Economy. mimeo.

Kim, S., 2001. International Transmission of U.S. Monetary Policy Shocks: Evidence from VAR's. Journal of Monetary Economics 48 (2), 339-372.

Kim, T. B., 2014. Analysis on Korean Economy with an Estimated DSGE Model after 2000. KDI Journal of Economic Policy 36 (2), 1-64.

Kimura, T., Nakajima, J., 2016. Identifying Conventional and Unconventional Monetary Policy Shocks: A Latent Threshold Approach. The B.E. Journal of Macroeconomics 16 (1), 277-300.

Klein, M., Shambaugh, J., 2015. Rounding the Corners of the Policy Trilemma: Sources of Monetary Policy Autonomy. American Economic Journal: Macroeconomics 7 (4), 33-66.

Kollmann, R., Enders, Z., Müller, G., 2011. Global banking and international business cycles. European Economic Review 55 (3), 407-426.

Kollmann, R., Pataracchia, B., Raciborski, R., Ratto, M., Roeger, W., Vogel, L., 2016. The Post-Crisis Slump in the Euro Area and the US: Evidence from an Estimated Three-region DSGE Model. European Economic Review C (88), 21-41.

Körner, J., 2015. Monetary Transmission in the Czech Republic after the Transformation. Eastern European Business and Economics Journal 1 (3), 19-47.

Kühl, M., 2016. The effects of government bond purchases on leverage constraints of banks and non-financial firms. Bundesbank Discussion Paper (38/2016).

Lane, P. R., Milesi-Ferretti, G. M., 2007. The External Wealth of Nations Mark II: Revised and Extended Estimates of Foreign Assets and Liabilities, 1970-2004. Journal of International Economics 73 (2), 223-250.

Leist, S., 2013. Driving Forces of the Swiss Output Gap. Swiss Journal of Economics and Statistics 149 (IV), 493-531.

Li, S., Spencer, A., 2015. Effectiveness of the Australian Fiscal Stimulus Package: A DSGE Analysis. Economic Record 92, 94-120. 
Linardi, F., 2016. Assessing the Fit of a Small Open-economy DSGE Model for the Brazilian Economy. Central Bank of Brazil WOrking Paper 424.

Lopez, M., Prada, J., Rodriguez, N., 2008. Financial Accelerator Mechanism in a Small Open Economy. Banco de la Republica de Colombia Borradores de Economia 525.

Lopez, M., Rodriguez, N., 2008. Financial Accelerator Mechanism: Evidence for Colombia. Banco de la Republica de Colombia Borradores de Economia 481.

Luciani, M., 03 2015. Monetary Policy and the Housing Market: A Structural Factor Analysis. Journal of Applied Econometrics 30 (2), 199-218.

Malakhovskaya, O., Minabutdinov, A., 2014. Are Commodity Price Shocks Important? A Bayesian Estimation of a DSGE Model for Russia. International Journal of Computational Economics and Econometrics 4 (1/2), 148-180.

Mandler, M., Scharnagl, M., Volz, U., 2016. Heterogeneity in euro-area monetary policy transmission: Results from a large multi-country BVAR model. Deutsche Bundesbank Discussion Paper 03/2016.

Medina, J. P., Soto, C., 2007. The Chilean Business Cycles Through the Lens of a Stochastic General Equilibrium Model. Central Bank of Chile Working Papers 457.

Melecky, M., Buncic, D., 2008. An Estimated, New Keynesian Policy Model for Australia. Economic Record 84 (264), 1-16.

Merola, R., 2015. The role of financial frictions during the crisis: An estimated DSGE model. Economic Modelling 48 (C), 70-82.

Milani, F., 2011. The Impact of Foreign Stock Markets on Macroeconomic Dynamics in Open Economies: A Structural Estimation. Journal of International Money and Finance 30 (1), $111-129$.

Milani, F., Park, S. H., 2015. The Effects of Globalization on Macroeconomic Dynamics in a Trade-dependent EEconomy: The Case of Korea. Economic Modelling 48 (C), 292-305.

Minetti, R., Peng, T., forthcoming. Credit Policies, Macroeconomic Stability and Welfare: The Case of China. Journal of Comparative Economics.

Miranda-Agrippino, S., 2016. Unsurprising Shocks: Information, Premia, and the Monetary Transmission. Bank of England Working Paper 626.

Miranda-Agrippino, S., Rey, H., 2015. World Asset Markets and the Global Financial Cycle. NBER Working Paper 21722.

Miyajima, K., Mohanty, M., Yetman, J., 2014. Spillovers of US Unconventional Monetary Policy to Asia: The Role of Long-term Interest Rates. BIS Working Paper 478.

Morais, B., Peydro, J., Ruiz, C., 2015. The International Bank Lending Channel of Monetary Policy Rates and QE: Credit Supply, Reach-for-Yield, and Real Effects. International Finance Discussion Papers 1137.

Mumtaz, H., Theophilopoulou, A., 2016. The Impact of Monetary Policy on Inequality in the UK: An Empirical Analysis. Queen Mary University of London Working Paper 738. 
Naraidoo, R., Paya, I., 2012. Forecasting Monetary Policy Rules in South Africa. International Journal of Forecasting 28 (2), 446-455.

Ncube, M., Ndou, E., 2011. Monetary Policy Transmission, House Prices and Consumer Spending in South Africa: An SVAR Approach. African Development Bank Working Paper 317.

Ncube, M., Ndou, E., 2013. Monetary Policy and Exchange Rate Shocks on South African Trade Balance. African Development Bank Working Paper 448.

Neuenkirch, M., 2013. Monetary Policy Transmission in Vector Autoregressions: A New Approach Using Central Bank Communication. Journal of Banking \& Finance 37 (11), $4278-4285$.

Nguyen, A., 2015. Financial Frictions and the Volatility of Monetary Policy in a DSGE Model. Lancaster University Management School Economics Department Working Paper $2015 / 006$.

Nobili, A., Neri, S., 2006. The Transmission of Monetary Policy Shocks from the US to the Euro Area. Bank of Italy Temi di Discussione 606.

Nuguer, V., 2016. Financial Intermediation in a Global Environment. International Journal of Central Banking 12.

Obstfeld, M., 2015. Trilemmas and Trade-offs: Living with Financial Globalisation. BIS Working Paper 480.

Obstfeld, M., Rogoff, K., 1996. Foundations of International Macroeconomics. No. 0262150476. The MIT Press.

Obstfeld, M., Shambaugh, J., Taylor, A., 2005. The Trilemma in History: Tradeoffs Among Exchange Rates, Monetary Policies, and Capital Mobility. The Review of Economics and Statistics 87 (3), 423-438.

Paetz, M., Gupta, R., 2016. Stock Price Dynamics and the Business Cycle in an Estimated DSGE Model for South Africa. Journal of International Financial Markets, Institutions and Money 18 (1), 166-182.

Passari, E., Rey, H., 2015. Financial Flows and the International Monetary System. Economic Journal 125 (584), 675-698.

Patra, M., Kapur, M., 2012. A Monetary Policy Model for India. Macroeconomics and Finance in Emerging Market Economies 5 (1), 18-41.

Peersman, G., Smets, F., 2001. The Monetary Transmission Mechanism in the Euro Area: More Evidence from VAR Analysis. ECB Working Paper 91.

Perez, F., 2015. Comparing the Transmission of Monetary Policy Shocks in Latin America: A Hierarchical Panel VAR. Banco Central de Reserva del Peru Working Paper 2015-015.

Phan, T., 09 2014. Output Composition of the Monetary Policy Transmission Mechanism: Is Australia Different? The Economic Record 90 (290), 382-399. 
Pop, R.-E., 2016. A Small-scale DSGE-VAR Model for the Romanian Economy. Economic Modelling.

Poutineau, J.-C., Vermandel, G., 2015a. Cross-border Banking Flows Spillovers in the Eurozone: Evidence from an Estimated DSGE Model. Journal of Economic Dynamics and Control 51, 378-403.

Poutineau, J.-C., Vermandel, G., 2015b. Financial Frictions and the Extensive Margin of Activity. Research in Economics 69 (4), 525-554.

Poutineau, J.-C., Vermandel, G., 2016. Global Banking and the Conduct of Macroprudential Policy in a Monetary Union. mimeo.

Pragidis, I., Gogas, P., Tabak, B., 2013. Asymmetric Effects of Monetary Policy in the US and Brazil. Democritus University of Thrace Research Papers in Economics 7-2013.

Quinn, D., Toyoda, M., 2008. Does Capital Account Liberalization Lead to Growth? Review of Financial Studies 21 (3), 1403-1449.

Quint, D., Rabanal, P., 2014. Monetary and Macroprudential Policy in an Estimated DSGE Model of the Euro Area. International Journal of Central Banking 10 (2), 169-236.

Raghavan, M., Athanasopoulos, G., Silvapulle, P., 2016. Canadian Monetary Policy Analysis Using a Structural VARMA Model. Canadian Journal of Economics 49 (1).

Razafindrabe, T., 2016. A Multi-country DSGE Model with Incomplete Exchange Rate Passthrough: An Application for the Euro-area. Economic Modelling 52, 78-100.

Rees, D., Smith, P., Hall, J., 2016. A Multi-sector Model of the Australian Economy. Economic Record 92 (298), 374-408.

Rey, H., 2015. Dilemma not Trilemma: The Global Financial Cycle and Monetary Policy Independence. NBER Working Paper 21162.

Robstad, Ø., 2014. House Prices, Credit and the Effect of Monetary Policy in Norway: Evidence from Structural VAR Models. Norges Bank Working Paper 2014/05.

Romer, C., Romer, D., 2004. A New Measure of Monetary Shocks: Derivation and Implications. American Economic Review 94 (4), 1055-1084.

Rossi, B., Zubairy, S., 2011. What Is the Importance of Monetary and Fiscal Shocks in Explaining U.S. Macroeconomic Fluctuations? Journal of Money, Credit and Banking 43 (6), 1247-1270.

Rudolf, B., Zurlinden, M., 2014. A Compact Open-Economy DSGE Model for Switzerland. Swiss National Bank Economic Studies 2014-08.

Rychalovska, Y., 2013. The Implications of Financial Frictions and Imperfect Knowledge in the Estimated DSGE Model of the US Economy. CERGE-EI Working Paper 482.

Rysanek, J., Tonner, J., Tvrz, S., Vasicek, O., 2012. Monetary Policy Implications of Financial Frictions in the Czech Republic. Czech Journal of Economics and Finance 62 (5), 413-429. 
Semko, R., 2013. Optimal Economic Policy and Oil Prices Shocks in Russia. Ekonomska Istrazivanja Economic Research 26 (2).

Senaj, M., Vyskrabka, M., Zeman, J., 2012. MUSE: Monetary Union and Slovak Economy Model. Ekonomicky casopis 5 (60).

Seneca, M., 2010. A DSGE Model for Iceland. Central bank of Iceland Working Paper 50.

Sheena, J., Wang, B., 2016. Assessing labor market frictions in a small open economy. Journal of Macroeconomics 48, 231-251.

Shulgin, A., 2017. Two-dimensional Monetary Policy Shocks in DSGE Model Estimated for Russia. Journal of New Economic Assosiation 1 (33).

Sims, C., 1998. Comment on Glenn Rudebusch's Do Measures of Monetary Policy in a VAR Make Sense? International Economic Review 39 (4), 933-41.

Sims, C., Zha, T., 2006. Were There Regime Switches in US Monetary Policy? American Economic Review 96 (1), 54-81.

Slanicay, M., 2011. Structural Differences and Asymmetric Shocks between the Czech Economy and the Euro Area 12. Review of Economic Perspectives 11 (3), 168-192.

Slanicay, M., 2013. Business Cycle Synchronization through the Lens of a DSGE Model. Czech Journal of Economics and Finance 63 (2), 180-196.

Slanicay, M., 2016a. A Proposal for a Flexible Trend Specification in DSGE Models. Review of Economic Perspectives 16 (2), 73-85.

Slanicay, M., 2016b. Analysis of Structural Differences and Asymmetry of Shocks Between the Czech Economy and the Euro Area. Statistika Journal 96 (1), 34-49.

Smets, F., Warne, A., Wouters, R., 2013. Professional Forecasters and the Real-time Forecasting Performance of an Estimated New Keynesian Model for the Euro Area. ECB Working Paper 1571.

Smets, F., Wouters, R., 2003. An Estimated Dynamic Stochastic General Equilibrium Model of the Euro Area. Journal of the European Economic Association 1 (5), 1123-1175.

Smith, L., Galesi, A., 2011. GVAR Toolbox 1.1 User Guide. mimeo.

Some, J., 2014. Welfare Effects of Oil Storage. mimeo.

Steinbach, R., Mathuloe, P., Smit, B., 2009. An Open-Economy New Keynesian DSGE Model of the South African Economy 09/01.

Timmer, M., Dietzenbacher, E., Los, B., Stehrer, R., Vries, G., 08 2015. An Illustrated User Guide to the World InputOutput Database: The Case of Global Automotive Production. Review of International Economics 23 (3), 575-605.

Tonner, J., Polansky, J., Vasicek, O., 2011. Parameter Drifting in a DSGE Model Estimated on Czech Data. Czech Journal of Economics and Finance 61 (5), 510-524.

Tonner, J., Tvrz, S., Vasicek, O., 2015. Labour Market Modelling within a DSGE Approach. Czech National Bank Working Papers 2015/06. 
Toroj, A., Konopczak, K., 2012. Crisis Resistance Versus Monetary Regime: A Polish Slovak Counterfactual Exercise. Central European Journal of Economic Modelling and Econometrics $4(1), 1-22$.

Tvrz, S., Vasicek, O., 2016. The Great Recession in the Non-EMU Visegrad Countries: A Nonlinear DSGE Model with Time-Varying Parameters. Czech Journal of Economics and Finance 66 (3), 207-235.

Ueda, K., 2012. Banking Globalization and International Business Cycles: Cross-border Chained Credit Contracts and Financial Accelerators. Journal of International Economics 86 (1), 1-16.

Villa, S., 2016. Financial Frictions in the Euro Area and the United States: A Bayesian Assessment. Macroeconomic Dynamics 20 (05), 1313-1340.

Vitek, F., 2014. Policy and Spillover Analysis in the World Economy: A Panel Dynamic Stochastic General Equilibrium Approach 14/200.

Vitek, F., 2015. Macrofinancial Analysis in the World Economy : A Panel Dynamic Stochastic General Equilibrium Approach. IMF Working Paper 15/227.

Voss, G., Willard, L., 2009. Monetary Policy and the Exchange Rate: Evidence from a Twocountry Model. Journal of Macroeconomics 31 (4), 708-720.

Yao, W., 2012. International Business Cycles and Financial Frictions. Bank of Canada Working Paper 12-19. 


\section{A Tables}

Table 1: Country Coverage of the Monetary Policy Shocks Database

\begin{tabular}{lcccccc}
\hline \hline & DSGE & FME & NARR & SM & VAR & Total \\
\hline AUS & 8 & 1 & 0 & 1 & 5 & 15 \\
BRA & 6 & 0 & 0 & 1 & 1 & 8 \\
CAN & 6 & 0 & 0 & 1 & 3 & 10 \\
CHE & 6 & 0 & 0 & 0 & 1 & 7 \\
CHL & 3 & 0 & 0 & 0 & 2 & 5 \\
CHN & 4 & 0 & 0 & 0 & 1 & 5 \\
COL & 5 & 0 & 0 & 0 & 2 & 7 \\
CZE & 12 & 0 & 0 & 0 & 2 & 14 \\
EAR & 35 & 1 & 0 & 0 & 13 & 49 \\
GBR & 12 & 3 & 1 & 0 & 7 & 23 \\
HUN & 1 & 0 & 0 & 0 & 0 & 1 \\
IND & 4 & 0 & 0 & 2 & 1 & 7 \\
ISL & 1 & 0 & 0 & 0 & 0 & 1 \\
ISR & 3 & 0 & 0 & 0 & 1 & 4 \\
JPN & 6 & 0 & 0 & 1 & 1 & 8 \\
KOR & 5 & 0 & 0 & 0 & 0 & 5 \\
MEX & 2 & 0 & 0 & 0 & 1 & 3 \\
NOR & 2 & 1 & 0 & 0 & 2 & 5 \\
NZL & 6 & 1 & 0 & 0 & 1 & 8 \\
PAK & 2 & 0 & 0 & 0 & 0 & 2 \\
PER & 1 & 0 & 0 & 0 & 2 & 3 \\
POL & 8 & 0 & 0 & 0 & 2 & 10 \\
ROU & 3 & 0 & 0 & 0 & 1 & 4 \\
RUS & 5 & 0 & 0 & 0 & 0 & 5 \\
SWE & 5 & 1 & 0 & 0 & 3 & 9 \\
THA & 2 & 0 & 0 & 0 & 0 & 2 \\
TUR & 2 & 0 & 0 & 0 & 0 & 2 \\
USA & 27 & 5 & 2 & 3 & 20 & 57 \\
ZAF & 4 & 0 & 0 & 1 & 3 & 8 \\
\hline Total & 186 & 13 & 3 & 10 & 75 & 287 \\
\hline \hline & & & & & &
\end{tabular}

Table 2: Model Type Coverage of the Monetary Policy Shocks Database

\begin{tabular}{lcc}
\hline \hline & Number of shocks & Percent \\
\hline DSGE & 186 & 64.8 \\
FME & 13 & 4.5 \\
NARR & 3 & 1.0 \\
SM & 10 & 3.5 \\
VAR & 75 & 26.1 \\
\hline Total & 287 & 100.0 \\
\hline \hline
\end{tabular}


Table 3: Overview of US Monetary Policy Shock Time Series Estimates

\begin{tabular}{|c|c|c|c|c|c|c|c|c|}
\hline Reference & Acronym & Type & Sample period & MC & SOE & FS & Pub & Keele \\
\hline Aguilar and Vzquez (2015) & agv & DSGE & $1965 q 2-2007 q 3$ & $\mathrm{n}$ & $\mathrm{n}$ & $\mathrm{n}$ & $\mathrm{n}$ & \\
\hline Alpanda and Aysun (2014) & aya & DSGE & $1996 q 1-2009 q 2$ & $\mathrm{y}$ & $\mathrm{n}$ & $\mathrm{y}$ & $\mathrm{y}$ & 3 \\
\hline Bacchiocchi and Fanelli (2015) & bf & VAR & $1956 \mathrm{q} 2-2008 \mathrm{q} 3$ & & & & $\mathrm{y}$ & 3 \\
\hline Bacchiocchi et al. (forthcoming) & bfc & VAR & 1961q1-2008q2 & & & & $\mathrm{y}$ & 2 \\
\hline Barakchian and Crowe (2013) & $\mathrm{bc}$ & FME & $1988 \mathrm{~m} 12-2008 \mathrm{~m} 6$ & & & & $\mathrm{y}$ & 4 \\
\hline Bernanke and Kuttner (2005) & bk & FME & $1988 \mathrm{~m} 12-2008 \mathrm{~m} 6$ & & & & $\mathrm{y}$ & 4 \\
\hline Bernanke and Mihov (1998) & $\mathrm{bm}$ & VAR & 1990m1-2007m11 & & & & $\mathrm{y}$ & 4 \\
\hline Bernanke et al. (2005) & bbe & VAR & 1960q1-2007q2 & & & & $\mathrm{y}$ & 4 \\
\hline Binder et al. (2010) & bcz & VAR & $1978 \mathrm{~m} 1-2006 \mathrm{~m} 12$ & & & & $\mathrm{n}$ & \\
\hline Brayton et al. (2014) & $\mathrm{frb}$ & DSGE & 1970q1-2010q4 & $\mathrm{y}$ & $\mathrm{n}$ & $\mathrm{n}$ & $\mathrm{y}$ & 3 \\
\hline Breuss and Fornero (2009) & forn & DSGE & $1984 q 1-2015 q 3$ & $\mathrm{y}$ & $\mathrm{n}$ & $\mathrm{n}$ & $\mathrm{n}$ & \\
\hline Burlon et al. (2016) & bnp & DSGE & $1995 q 2-2014 q 4$ & $\mathrm{y}$ & $\mathrm{n}$ & $*$ & $\mathrm{n}$ & \\
\hline Caglayan et al. (2016) & $\mathrm{ckm}$ & NARR & $1970 q 4-2008 q 4$ & & & & $\mathrm{n}$ & 3 \\
\hline Carabenciov et al. (2008) & gpm & DSGE & 1994q1-2008q1 & $\mathrm{y}$ & $\mathrm{n}$ & $\mathrm{y}$ & $\mathrm{n}$ & \\
\hline Carlstrom et al. (2014) & cfop & DSGE & $1972 q 2-2008 q 4$ & $\mathrm{n}$ & $\mathrm{n}$ & $\mathrm{n}$ & $\mathrm{y}$ & 3 \\
\hline Ca'Zorzi et al. (2016) & jp & DSGE & 1975q1-2013q3 & $\mathrm{n}$ & $\mathrm{n}$ & $\mathrm{n}$ & $\mathrm{y}$ & 3 \\
\hline Chin et al. (2015) & $\mathrm{cft}$ & DSGE & 1976q1-2013q2 & $\mathrm{n}$ & $\mathrm{n}$ & $\mathrm{n}$ & $\mathrm{n}$ & \\
\hline Christiano et al. (1999) & cee & VAR & $1989 q 4-2007 q 3$ & & & & $\mathrm{y}$ & 0 \\
\hline Christiano et al. (2014) & $\mathrm{cmr}$ & DSGE & 1981q1-2010q2 & $\mathrm{n}$ & $\mathrm{n}$ & $\mathrm{n}$ & $\mathrm{y}$ & 4 \\
\hline Chung et al. (2010) & edo & DSGE & $1984 q 4-2016 q 2$ & $\mathrm{n}$ & $\mathrm{n}$ & $\mathrm{n}$ & $\mathrm{n}$ & \\
\hline Claus and Dungey (2012) & cld & SM & $1994 \mathrm{~m} 1 \mathrm{~d} 1-2008 \mathrm{~m} 10 \mathrm{~d} 31$ & & & & $\mathrm{y}$ & 3 \\
\hline Claus et al. (2016) & cck & $\mathrm{SM}$ & $1996 \mathrm{~m} 1 \mathrm{~d} 1-2015 \mathrm{~m} 11 \mathrm{~d} 30$ & & & & $\mathrm{n}$ & \\
\hline Consensus Forecast & $\operatorname{cpf}$ & FME & 1990q1-2013q1 & & & & $\mathrm{n}$ & \\
\hline Dungey and Osborn (2014) & duo & VAR & 1983q1-2007q4 & & & & $\mathrm{y}$ & 3 \\
\hline Dungey et al. (2014) & dor & VAR & $1984 q 3-2008 q 1$ & & & & $\mathrm{y}$ & 2 \\
\hline Feldkircher and Huber (2016) & fel & VAR & 1995q1-2012q4 & & & & $\mathrm{y}$ & 4 \\
\hline Forni and Gambetti (2010) & $\mathrm{fg}$ & VAR & $1990 \mathrm{~m} 1-2007 \mathrm{~m} 11$ & & & & $\mathrm{y}$ & 4 \\
\hline Fragetta and Melina (2013) & frm & VAR & $1965 q 4-2007 q 4$ & & & & $\mathrm{y}$ & 2 \\
\hline Furlanetto et al. (2014) & fgs & DSGE & $1964 q 2-2009 q 4$ & $\mathrm{n}$ & $\mathrm{n}$ & $\mathrm{n}$ & $\mathrm{n}$ & \\
\hline Galí and Gambetti (2015) & gag & VAR & 1960q1-2011q4 & & & & $\mathrm{y}$ & 3 \\
\hline Gazzani and Vicondoa (2016) & gvi1 & VAR & $1991 \mathrm{~m} 1-2007 \mathrm{~m} 7$ & & & & $\mathrm{n}$ & \\
\hline Gazzani and Vicondoa (2016) & gvi2 & VAR & 1991m1-2007m7 & & & & $\mathrm{n}$ & \\
\hline Gertler and Karadi (2015) & $\mathrm{kg}$ & FME & 1991m1-2012m6d30 & & & & $\mathrm{y}$ & 3 \\
\hline Gertler et al. (2008) & gst & DSGE & 1960q1-2005q1 & $\mathrm{n}$ & $\mathrm{n}$ & $\mathrm{n}$ & $\mathrm{y}$ & 3 \\
\hline Heinlein and Krolzig (2013) & hek & VAR & $1972 \mathrm{~m} 3-2010 \mathrm{~m} 8$ & & & & $\mathrm{n}$ & \\
\hline Iacoviello and Neri (2010) & in & DSGE & 1965q1-2006q4 & $\mathrm{n}$ & $\mathrm{n}$ & $\mathrm{n}$ & $\mathrm{y}$ & 3 \\
\hline Kaihatsu and Kurozumi (2014) & kak & DSGE & $1985 q 1-2008 q 4$ & $\mathrm{n}$ & $\mathrm{n}$ & $\mathrm{n}$ & $\mathrm{y}$ & 3 \\
\hline Kamber et al. (2015) & kst & DSGE & $1954 q 3-2011 q 4$ & $\mathrm{n}$ & $\mathrm{n}$ & $\mathrm{n}$ & $\mathrm{y}$ & 2 \\
\hline Kollmann et al. (2016) & quest & DSGE & 1999q1-2015q1 & $\mathrm{y}$ & $\mathrm{n}$ & $\mathrm{n}$ & $\mathrm{y}$ & 4 \\
\hline Luciani (2015) & luc & VAR & 1983q1-2010q4 & & & & $\mathrm{y}$ & 3 \\
\hline Merola (2015) & swrm & DSGE & 1965Q1-2012Q4 & $\mathrm{n}$ & $\mathrm{n}$ & $\mathrm{n}$ & $\mathrm{y}$ & 2 \\
\hline Merola (2015) & swrmff & DSGE & $1965 q 1-2012 q 4$ & $\mathrm{n}$ & $\mathrm{n}$ & $\mathrm{n}$ & $\mathrm{y}$ & 2 \\
\hline Miranda-Agrippino (2016) & sma & FME & $1990 \mathrm{~m} 1-2009 \mathrm{~m} 12$ & & & & $\mathrm{n}$ & \\
\hline Nguyen (2015) & ngu & DSGE & 1960q1-2007q1 & $\mathrm{n}$ & $\mathrm{n}$ & $\mathrm{n}$ & $\mathrm{n}$ & \\
\hline Phan (2014) & pta & VAR & $1982 q 4-2007 q 4$ & & & & $\mathrm{y}$ & 2 \\
\hline Poutineau and Vermandel (2015b) & pov1 & DSGE & 1993q1-2012q3 & $\mathrm{n}$ & $\mathrm{n}$ & $\mathrm{n}$ & $\mathrm{y}$ & 1 \\
\hline Pragidis et al. (2013) & pgt & $\mathrm{SM}$ & $1980 \mathrm{~m} 1-2011 \mathrm{~m} 10$ & & & & $\mathrm{n}$ & \\
\hline Razafindrabe (2016) & $\mathrm{raz}$ & DSGE & 1999q1-2011q2 & $\mathrm{y}$ & $\mathrm{n}$ & $\mathrm{n}$ & $\mathrm{y}$ & 2 \\
\hline Romer and Romer (2004) & $\mathrm{rr}$ & NARR & $1988 \mathrm{~m} 1-2008 \mathrm{~m} 6$ & & & & $\mathrm{y}$ & 4 \\
\hline Rossi and Zubairy (2011) & $\mathrm{rOz}$ & VAR & $1955 q 3-2006 q 4$ & & & & $\mathrm{y}$ & 3 \\
\hline Rychalovska (2013) & ryc1 & DSGE & $1954 q 1-2008 q 3$ & $\mathrm{n}$ & $\mathrm{n}$ & $\mathrm{n}$ & $\mathrm{y}$ & 3 \\
\hline Sims and Zha (2006) & sZ & VAR & $1989 q 4-2008 q 2$ & & & & $\mathrm{y}$ & 2 \\
\hline Some $(2014)$ & som & DSGE & $1973 q 1-2005 q 4$ & $\mathrm{y}$ & $\mathrm{n}$ & $\mathrm{n}$ & $\mathrm{n}$ & \\
\hline Villa (2016) & vbgg & DSGE & 1983q1-2008q3 & $\mathrm{n}$ & $\mathrm{n}$ & $\mathrm{n}$ & $\mathrm{y}$ & 2 \\
\hline Villa (2016) & vgk & DSGE & 1983q1-2008q3 & $\mathrm{n}$ & $\mathrm{n}$ & $\mathrm{n}$ & $\mathrm{y}$ & 2 \\
\hline Vitek $(2015)$ & vit & DSGE & $1999 q 3-2008 q 4$ & $\mathrm{y}$ & $\mathrm{n}$ & $\mathrm{y}$ & $\mathrm{n}$ & \\
\hline Voss and Willard (2009) & vow & VAR & $1985 q 2-2007 q 4$ & & & & $\mathrm{y}$ & 2 \\
\hline
\end{tabular}

Note: The table lists the studies from which we obtained monetary policy shock time series estimates for the US. Regarding model types, "FME" stands for financial market expectations, "NARR" for the narrative approach, and "SM" for statistical model. "MC" for multi-country model, "SOE" for small open-economy model, "FS" for whether the model involves frictions in international financial markets, "Pub" for published, and "Keele" for the journal ranking in the Keele list. For journals which are not included in the original Keele list, we allocated the International Journal of Central Banking, the American Economic Journal: Macroeconomics, the Journal of Financial Stability, and the Economic Journal to rank three, and The B.E. Journal of Macroeconomics, Manchester School, and the South African Journal of Economics to rank two. We construct monetary policy shocks for the US based on Consensus Forecast data as described in Appendix C.1. * indicates that no model documentation is currently available. 
Table 4: Overview of Euro Area Monetary Policy Shock Time Series Estimates

\begin{tabular}{|c|c|c|c|c|c|c|c|c|}
\hline Reference & Acronym & Тype & Sample period & MC & SOE & FS & Pub & Keele \\
\hline Albonico et al. (2014) & alb1 & DSGE & $1993 q 2-2012 q 4$ & $\mathrm{n}$ & $\mathrm{n}$ & $\mathrm{n}$ & $\mathrm{n}$ & \\
\hline Albonico et al. (forthcoming) & alb2 & DSGE & $1985 q 1-2012 q 4$ & $\mathrm{n}$ & $\mathrm{n}$ & $\mathrm{n}$ & $\mathrm{y}$ & 2 \\
\hline Alpanda and Aysun (2014) & aya & DSGE & 1996q1-2009q2 & $\mathrm{y}$ & $\mathrm{n}$ & $\mathrm{y}$ & $\mathrm{y}$ & 3 \\
\hline Avouyi-Dovi and Sahuc (2016) & ads & DSGE & $1980 q 2-2007 q 4$ & $\mathrm{n}$ & $\mathrm{n}$ & $\mathrm{n}$ & $\mathrm{y}$ & 4 \\
\hline Babecka Kucharcukova et al. (2016) & $\mathrm{bab}$ & VAR & $2001 \mathrm{~m} 4-2015 \mathrm{~m} 7$ & & & & $\mathrm{y}$ & 2 \\
\hline Gregor Bäurle and Känzig (2016) & bgk & VAR & 1992q3-2011q2 & & & & $\mathrm{n}$ & \\
\hline Barigozzi et al. (2014) & bcl & VAR & $1984 q 1-2007 q 4$ & & & & $\mathrm{y}$ & 3 \\
\hline Benchimol and Fourcans (forthcoming) & benf & DSGE & $1995 q 2-2013 q 1$ & $\mathrm{n}$ & $\mathrm{n}$ & $\mathrm{n}$ & $\mathrm{y}$ & 2 \\
\hline Benkovskis et al. (2011) & bbfw & VAR & $1999 q 3-2010 q 3$ & & & & $\mathrm{y}$ & 0 \\
\hline Boivin et al. (2009) & bgm & VAR & $1988 q 1-2007 q 3$ & & & & $\mathrm{n}$ & \\
\hline Breuss and Fornero (2009) & forn & DSGE & $1984 q 1-2015 q 3$ & $\mathrm{y}$ & $\mathrm{n}$ & $\mathrm{n}$ & $\mathrm{n}$ & \\
\hline Burlon et al. (2016) & bnp & DSGE & $1995 q 2-2014 q 4$ & $\mathrm{y}$ & $\mathrm{n}$ & $*$ & $\mathrm{n}$ & \\
\hline Carabenciov et al. (2008) & gpm & DSGE & $1994 q 1-2008 q 1$ & $\mathrm{y}$ & $\mathrm{n}$ & $\mathrm{y}$ & $\mathrm{n}$ & \\
\hline Ca'Zorzi et al. (2016) & jp & DSGE & $1975 q 1-2013 q 3$ & $\mathrm{n}$ & $\mathrm{y}$ & $\mathrm{n}$ & $\mathrm{y}$ & 3 \\
\hline Christoffel et al. (2008) & nawm & DSGE & $1985 q 1-2011 q 4$ & $\mathrm{n}$ & $\mathrm{y}$ & $\mathrm{n}$ & $\mathrm{y}$ & 3 \\
\hline Consensus Forecast & cpf & FME & 1990q1-2013q1 & & & & & \\
\hline DiCecio and Nelson (2010) & den & DSGE & $1981 q 1-2005 q 4$ & $\mathrm{y}$ & $\mathrm{n}$ & $\mathrm{n}$ & $\mathrm{y}$ & 0 \\
\hline Dungey and Osborn (2014) & duo & VAR & $1983 q 1-2007 q 4$ & & & & $\mathrm{y}$ & 3 \\
\hline Dungey et al. (2014) & dor & VAR & $1984 q 3-2008 q 1$ & & & & $\mathrm{y}$ & 2 \\
\hline Errit and Uusküla (2014) & ues & VAR & $2000 q 3-2012 q 4$ & & & & $\mathrm{y}$ & 0 \\
\hline Feve and Sahuc (2016) & fes & DSGE & $1980 q 2-2007 q 4$ & $\mathrm{n}$ & $\mathrm{n}$ & $\mathrm{n}$ & $\mathrm{y}$ & 3 \\
\hline Gadatsch et al. (2016) & gear & DSGE & $1999 q 2-2013 q 4$ & $\mathrm{n}$ & $\mathrm{y}$ & $\mathrm{n}$ & $\mathrm{y}$ & 2 \\
\hline Gelain (2010) & gel & DSGE & $1980 q 1-2008 q 3$ & $\mathrm{n}$ & $\mathrm{n}$ & $\mathrm{n}$ & $\mathrm{y}$ & 1 \\
\hline Gerali et al. (2010) & ger & DSGE & $1998 q 1-2009 q 4$ & $\mathrm{n}$ & $\mathrm{n}$ & $\mathrm{n}$ & $\mathrm{y}$ & 3 \\
\hline Giri (2014) & gir & DSGE & $1998 \mathrm{q} 1-2014 q 2$ & $\mathrm{n}$ & $\mathrm{n}$ & $\mathrm{n}$ & $\mathrm{n}$ & \\
\hline Herber and Nemec (2012) & hen2 & DSGE & $1999 \mathrm{q} 1-2009 \mathrm{q} 4$ & $\mathrm{n}$ & $\mathrm{y}$ & $\mathrm{n}$ & $\mathrm{y}$ & 0 \\
\hline Hristov (2016) & ifo & DSGE & $2000 q 1-2016 q 2$ & $\mathrm{n}$ & $\mathrm{y}$ & $\mathrm{n}$ & $\mathrm{n}$ & \\
\hline Jannsen and Klein (2011) & $\mathrm{jk}$ & VAR & $1990 \mathrm{q} 1-2008 \mathrm{q} 4$ & & & & $\mathrm{n}$ & \\
\hline Kollmann et al. (2016) & quest & DSGE & 1999q1-2015q1 & $\mathrm{y}$ & $\mathrm{n}$ & $\mathrm{n}$ & $\mathrm{y}$ & 4 \\
\hline Kühl (2016) & kue & DSGE & $1997 q 4-2013 q 3$ & $\mathrm{n}$ & $\mathrm{n}$ & $\mathrm{n}$ & $\mathrm{n}$ & \\
\hline Mandler et al. (2016) & msv & VAR & $1999 \mathrm{q} 1-2014 \mathrm{q} 3$ & & & & $\mathrm{n}$ & \\
\hline Neuenkirch (2013) & neu & VAR & $1999 \mathrm{~m} 1-2012 \mathrm{~m} 12$ & & & & $\mathrm{y}$ & 3 \\
\hline Peersman and Smets (2001) & ovar & VAR & 1990q2-2011q2 & & & & $\mathrm{n}$ & \\
\hline Phan (2014) & pta & VAR & $1982 q 4-2007 q 4$ & & & & $\mathrm{y}$ & 2 \\
\hline Poutineau and Vermandel (2015a) & pov2 & DSGE & $1999 q 1-2013 q 3$ & $\mathrm{n}$ & $\mathrm{n}$ & $\mathrm{n}$ & $\mathrm{y}$ & 3 \\
\hline Poutineau and Vermandel (2016) & pov3 & DSGE & $1999 q 1-2013 q 4$ & $\mathrm{n}$ & $\mathrm{n}$ & $\mathrm{n}$ & $\mathrm{n}$ & \\
\hline Quint and Rabanal (2014) & qir & DSGE & 1996q1-2011q4 & $\mathrm{n}$ & $\mathrm{n}$ & $\mathrm{n}$ & $\mathrm{y}$ & 3 \\
\hline Razafindrabe (2016) & $\mathrm{raz}$ & DSGE & $1999 \mathrm{q} 1-2011 \mathrm{q} 2$ & $\mathrm{y}$ & $\mathrm{n}$ & $\mathrm{n}$ & $\mathrm{y}$ & 2 \\
\hline Senaj et al. (2012) & svz & DSGE & 1997q1-2016q2 & $\mathrm{y}$ & $\mathrm{n}$ & $\mathrm{n}$ & $\mathrm{y}$ & 0 \\
\hline Slanicay (2011) & rep2 & DSGE & 1999q1-2010q2 & $\mathrm{n}$ & $\mathrm{y}$ & $\mathrm{n}$ & $\mathrm{y}$ & 0 \\
\hline Slanicay (2013) & cjef & DSGE & $2000 \mathrm{q} 2-2011 \mathrm{q} 3$ & $\mathrm{y}$ & $\mathrm{n}$ & $\mathrm{n}$ & $\mathrm{y}$ & 0 \\
\hline Slanicay (2016b) & sta & DSGE & $2000 \mathrm{q} 2-2014 \mathrm{q} 1$ & $\mathrm{y}$ & $\mathrm{n}$ & $\mathrm{n}$ & $\mathrm{y}$ & 0 \\
\hline Slanicay (2016a) & rep1 & DSGE & $2000 q 2-2014 q 1$ & $\mathrm{y}$ & $\mathrm{n}$ & $\mathrm{n}$ & $\mathrm{y}$ & 0 \\
\hline Smets et al. (2013) & sww & DSGE & $1970 \mathrm{q} 2-2010 \mathrm{q} 2$ & $\mathrm{n}$ & $\mathrm{n}$ & $\mathrm{n}$ & $\mathrm{y}$ & 2 \\
\hline Some $(2014)$ & som & DSGE & $1973 q 1-2005 q 4$ & $\mathrm{y}$ & $\mathrm{n}$ & $\mathrm{n}$ & $\mathrm{n}$ & \\
\hline Toroj and Konopczak (2012) & tor & DSGE & $1995 q 2-2011 q 2$ & $\mathrm{y}$ & $\mathrm{n}$ & $\mathrm{n}$ & $\mathrm{y}$ & 0 \\
\hline Villa $(2016)$ & vbgg & DSGE & $1983 q 1-2008 q 3$ & $\mathrm{n}$ & $\mathrm{n}$ & $\mathrm{n}$ & $\mathrm{y}$ & 2 \\
\hline Villa (2016) & vgk & DSGE & 1983q1-2008q3 & $\mathrm{n}$ & $\mathrm{n}$ & $\mathrm{n}$ & $\mathrm{y}$ & 2 \\
\hline Vitek (2015) & vit & DSGE & $1999 q 3-2008 q 4$ & $\mathrm{y}$ & $\mathrm{n}$ & $\mathrm{y}$ & $\mathrm{n}$ & \\
\hline
\end{tabular}

Note: See the note to Table 3. 
Table 5: Overview of UK Monetary Policy Shock Time Series Estimates

\begin{tabular}{|c|c|c|c|c|c|c|c|c|}
\hline Reference & Acronym & Type & Sample period & $\mathrm{MC}$ & SOE & FS & Pub & Keele \\
\hline Ajevskis and Vitola (2011) & vaj & DSGE & 1996q1-2010q1 & $\mathrm{n}$ & $\mathrm{y}$ & $\mathrm{n}$ & $\mathrm{n}$ & \\
\hline Andreasen (2012) & and & DSGE & 1990q1-2008q3 & $\mathrm{n}$ & $\mathrm{n}$ & $\mathrm{n}$ & $\mathrm{y}$ & 4 \\
\hline Babecka Kucharcukova et al. (2016) & $\mathrm{bab}$ & VAR & $2001 \mathrm{~m} 4-2015 \mathrm{~m} 7$ & & & & $\mathrm{y}$ & 2 \\
\hline Bhattaraia and Trzeciakiewiczb (2017) & bht & DSGE & 1987q2-2011q1 & $\mathrm{n}$ & $\mathrm{n}$ & $\mathrm{n}$ & $\mathrm{y}$ & 2 \\
\hline Bjørnland and Jacobsen (2010) & bjo & VAR & $1983 q 1-2006 q 4$ & & & & $\mathrm{y}$ & 3 \\
\hline Burgess et al. (2013) & boe & DSGE & $1987 q 3-2007 q 4$ & $\mathrm{n}$ & $\mathrm{y}$ & $\mathrm{n}$ & $\mathrm{n}$ & \\
\hline Ca'Zorzi et al. (2016) & jp & DSGE & 1975q1-2013q3 & $\mathrm{n}$ & $\mathrm{y}$ & $\mathrm{n}$ & $\mathrm{y}$ & 3 \\
\hline Cesa-Bianchi et al. (2016) & ctv & FME & $1997 \mathrm{~m} 7 \mathrm{~d} 1-2015 \mathrm{~m} 6 \mathrm{~d} 30$ & & & & $\mathrm{n}$ & \\
\hline Chen and Macdonald (2012) & $\mathrm{cmc}$ & DSGE & $1975 \mathrm{q} 2-2010 \mathrm{q} 2$ & $\mathrm{n}$ & $\mathrm{y}$ & $\mathrm{n}$ & $\mathrm{y}$ & 3 \\
\hline Chin et al. (2015) & $\mathrm{cft}$ & DSGE & 1976q1-2013q2 & $\mathrm{n}$ & $\mathrm{y}$ & $\mathrm{y}$ & $\mathrm{n}$ & \\
\hline Cloyne and Hürtgen (forthcoming) & $\operatorname{clh}$ & NARR & $1975 \mathrm{~m} 1-2007 \mathrm{~m} 12$ & & & & $\mathrm{y}$ & 3 \\
\hline Consensus Forecast & $\mathrm{cpf}$ & FME & 1990q1-2013q1 & & & & & \\
\hline DiCecio and Nelson (2010) & den & DSGE & 1981q1-2005q4 & $\mathrm{y}$ & $\mathrm{n}$ & $\mathrm{n}$ & $\mathrm{y}$ & 0 \\
\hline Ellis et al. (2014) & mum & VAR & $1976 q 1-2005 q 4$ & & & & $\mathrm{y}$ & 3 \\
\hline Faccini et al. (2013) & $\mathrm{fmz}$ & DSGE & $1971 q 1-2009 q 4$ & $\mathrm{n}$ & $\mathrm{n}$ & $\mathrm{n}$ & $\mathrm{y}$ & 2 \\
\hline Felcser and Vonnak (2014) & fev & VAR & $1993 q 2-2007 q 4$ & & & & $\mathrm{n}$ & \\
\hline Harrison and Oomen (2010) & harr & DSGE & $1958 \mathrm{q} 1-2007 q 1$ & $\mathrm{n}$ & $\mathrm{y}$ & $\mathrm{n}$ & $\mathrm{n}$ & \\
\hline Heinlein and Krolzig (2013) & hek & VAR & $1972 \mathrm{~m} 3-2010 \mathrm{~m} 8$ & & & & $\mathrm{n}$ & \\
\hline Kamber and Millard (2012) & $\mathrm{km}$ & VAR & $1979 q 4-2007 q 4$ & & & & $\mathrm{y}$ & 3 \\
\hline Miranda-Agrippino (2016) & sma & FME & $2000 \mathrm{~m} 1-2012 \mathrm{~m} 6$ & & & & $\mathrm{n}$ & \\
\hline Mumtaz and Theophilopoulou (2016) & mut & VAR & $1976 q 2-2009 q 1$ & & & & $\mathrm{n}$ & \\
\hline Razafindrabe (2016) & $\mathrm{raz}$ & DSGE & $1999 q 1-2011 q 2$ & $\mathrm{y}$ & $\mathrm{n}$ & $\mathrm{n}$ & $\mathrm{y}$ & 2 \\
\hline Vitek (2015) & vit & DSGE & $1999 q 3-2008 q 4$ & $\mathrm{y}$ & $\mathrm{n}$ & $\mathrm{y}$ & $\mathrm{n}$ & \\
\hline
\end{tabular}

Note: See the note to Table 3. 
Table 6: Overview of Non-US, Non-Euro Area and Non-UK Monetary Policy Shock Time

Reference Series Estimates

Adame et al. (2016)

Adolfson et al. (2011)

Ahmad (2017)

Ahmed et al. (2014)

Ajevskis and Vitola (2011)

Alp and Elekdag (2013)

Alp et al. (2012)

Argov et al. (2012)
Assenmacher-Wesche (2008)

Azoulay and Ribon (2010)

Babecka Kucharcukova et al. (2016)

Bank of Korea

Baranowski et al. (2016)

Barnett et al. (2015)

Beltran and Draper (2008)

Benchimol (2016)

Bjørnland and Jacobsen (2010)

Brzoza-Brzezina and Makarski (2011)

Melecky and Buncic (2008)
Melecky and Buncic (2008)

Melecky and Buncic (2008)
Carabenciov et al. (2008)

Caraiani (2013)

Ca'Zorzi et al. (2016)

Chen and Columba (2016)

Claus and Dungey (2016

Claus et al. (2016)

Copaciu et al. (2016)

Cuche-Curti et al. (2009)

Dadam and Viegi (2014)

Dai et al. (2015)

de Carvalho and Castro (2015)

de Carvalho and Valli (2011)
de Carvalho et al. (2014)

de Carvalho et al. (2014)
Bong et al. (2016)

Dorich et al. (2013)

Drygalla (2015)

Felcser and Vonnak (2014)

Fueki et al. (2016)

Gabriel et al. (2012)

Gallic and Vermandel (2016)

Garcia and Gonzalez (2014)

Gerdrup et al. (2017)

Gervais and Gosselin (2014)

Gonzalez et al. (2015)

Goyal and Kumar (2016)

Grabek and Klos (2013)

Herber and Nemec (2009)

Herber and Nemec (2012)

Hernan Hernandez and Ortiz Bolanos (2016)

Hirose (2014)

IMF (2017)

Jiang and Kim (2013)

Junicke (2015)

Kamber et al. (2016)

Kapur and Behera (2012)

Katagiri and Takahashi (2016)

Kim (2014)

Kimura and Nakajima (2016)

Körner (2015)

Kreptsev and Seleznev (2016)

Leist (2013)

$\mathrm{Li}$ and Spencer (2015)

Linardi (2016)

Lopez and Rodriguez (2008)

Lopez et al. (2008)

Malakhovskaya and Minabutdinov (2014)

Medina and Soto (2007)

Milani (2011)

Milani and Park (2015)

Minetti and Peng (forthcoming)

Naraidoo and Paya (2012)

Ncube and Ndou (2011)

Ncube and Ndou (2013)

Paetz and Gupta (2016)

Patra and Kapur (2012)

Perez (2015)

Phan (2014)

Pop (2016)

Pragidis et al. (2013)

Raghavan et al. (2016)

Raghavan et al. (2016)

Razafindrabe (2016)

Rees et al. (2016)

Rudolf and Zurlinden (2014)

Rysanek et al. (2012)

Rysanek et al.
Semko (2013)

Seneca (2010)

Sheena and Wang (2016)

Shulgin (2017)

Slanicay (2011)

Slanicay (2013)

Slanicay (2016b)

Steinbach et al. (2009)

Sveriges Riksbank

Tonner et al. (2011)

Tonner et al. (2015)
Toroj and Konopczak (2012)

Toroj and Konopczak (2012)

Vitek (2015)

Acronym Country

Type Sample period

MC SOE FS Pub Keele

$\begin{array}{cl}\text { acrz } & \text { MEX } \\ \text { ado } & \text { SWE }\end{array}$

rams SWE

ahm PAK

amr PAK

aj CZE, POL, SWE

ael KOR

moi ISR

asw $\quad \mathrm{CHE}$

bab SWE, POL, CZE

bok KOR

$\begin{array}{ll}\text { bot } & \text { THA } \\ \text { boms } & \text { POL }\end{array}$

gho IND

bel $\mathrm{CHE}$

bjo NOR, SWE

boL

bud AUS
buv AUS

gpm JPN

car HUN

$\begin{array}{ll}\text { jp } & \text { AUS, } \\ \text { cco } & \text { SWE }\end{array}$

cd AUS, CAN

cck JPN

cdn CHE

dav ZAF

dc BRA

$\begin{array}{ll}\text { dv } & \text { BRA } \\ \text { dcc } & \text { BRA }\end{array}$

dpb AUS, NZL, CAN

tot CAN

fev AUS, CAN

fue JPN

glpy IND

gly IND

gga AUS, CHL, COL, NZL, PER

AUS, C

CAN

$\begin{array}{ll}\text { lens } & \text { CAN } \\ \text { ghr } & \text { COL }\end{array}$

gku IND

gs ZAF

hen2 CZE

hhob BRA, CHL, COL, MEX, PER

$\mathrm{PN}$

gfsr AUS, NOR, NZL, SWE

jam NZL

jkc CHN

nzsim NZL

kbe IND

$\begin{array}{ll}\text { kta } & \text { JPN } \\ \text { KOR }\end{array}$

nik JPN

$\begin{array}{ll}\text { koe } & \text { CZE } \\ \text { krs } & \text { RUS }\end{array}$

lei CHE

lsp AUS

lin $\quad$ BRA

lpr COI

mmi RUS

mil2 AUS, CAN, NZL

mil KOR

tpe CHN

run $\mathrm{ZAF}$

nd1 ZAF

pag ZAF

pef BRA, CHL, COL, MEX, PER

US

pre ROM

pgt BRA

ras1 CAN

JPN, CHE, CHN

rsh AUS

rob NOR

ruz $\quad$ CHE

sem RUS

ice ISL

$\begin{array}{ll}\text { shw } & \text { AUS } \\ \text { shu } & \text { RUS }\end{array}$

rep2 CZE

cjef CZE

sta $\quad$ CZE

sms ZAF

bvar SWE

tpv $\quad$ CZE

tor $\mathrm{POL}$

NZL, AUS, SWE, CAN, ZAF, KOR, CHN, JPN, CHE, ISR, CHL, DSGE IND, TUR, COL, CZE

2001q1-2016q2

n $y+n-m$

$\begin{array}{lllllll}\text { DSGE } & \text { 2001q1-2016q2 } & \mathrm{n} & \mathrm{y} & \mathrm{n} & \mathrm{n} & \\ \text { DSGE } & 1980 \mathrm{q} 2-2007 \mathrm{q} 3 & \mathrm{n} & \mathrm{y} & \mathrm{n} & \mathrm{y} & 3\end{array}$

DSGE $\quad 1995 q^{2}-2015 q 2$

DSGE $1980 \mathrm{q} 4-2016 \mathrm{q}$

DSGE 19804-2016q2

DSGE - 1996q-2010q

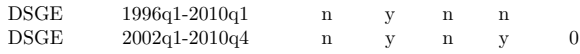

$\begin{array}{llllll}\text { DSGE } & 2000 \mathrm{q} 1-2012 \mathrm{q} 4 & \mathrm{n} & \mathrm{y} & \mathrm{n} & \mathrm{y}\end{array}$

$\begin{array}{llll}\text { DSGE } & 1992 \mathrm{q} 1-2011 \mathrm{q} 4 & \mathrm{n} & \mathrm{y} \\ \mathrm{VAR} & \mathrm{y}\end{array}$

VAR 1975q1-2006q4

VAR $\quad 2000 \mathrm{~m} 1-2008 \mathrm{~m} 12$

$2001 \mathrm{~m} 4-2015 \mathrm{~m} 7$ y 2

$\begin{array}{llllll}\text { DSGE } & 2001 \mathrm{q} 1-2015 \mathrm{q} 2 & * & * & * & \\ \text { 2002q1-2015q3 } & \mathrm{n} & \mathrm{n} & \mathrm{n} & \mathrm{n}\end{array}$

$\begin{array}{lllllll}\text { DSGE } & 1997 \mathrm{q} 1-2012 \mathrm{q} 4 & \mathrm{n} & \mathrm{n} & \mathrm{n} & \mathrm{y} & 0\end{array}$

VAR 1996m1-2013m12

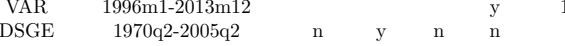

$\begin{array}{lllllll}\text { DSGE } & 1995 \mathrm{q} 2-2013 \mathrm{q} 1 & \mathrm{n} & \mathrm{n} & \mathrm{n} & \mathrm{y} & 2\end{array}$

VAR 1983q1-2006q

$\begin{array}{lllllll}\text { DSGE } & 1984 q 1-2005 q 4 & n & y & n & y & 3 \\ \text { VAR } & 198 q 1-200 q 4 & & & & y & \end{array}$

VAR $1984 \mathrm{q} 1-2005 \mathrm{q} 4$

$\begin{array}{lllllll}\text { DSGE } & 1994 \mathrm{q} 1-2008 \mathrm{q} 1 & \mathrm{y} & \mathrm{n} & \mathrm{y} & \mathrm{n} & \\ \text { DSGE } & \text { 2000q1-2010q2 } & \mathrm{n} & \mathrm{y} & \mathrm{n} & \mathrm{y} & 2 \\ \text { DSGE } & 1975 \mathrm{q} 1-2013 \mathrm{q} 3 & \mathrm{n} & \mathrm{y} & \mathrm{n} & \mathrm{y} & 3 \\ \text { DSGE } & 1996 \mathrm{q} 1-2014 \mathrm{q} 4 & \mathrm{n} & \mathrm{y} & \mathrm{n} & \mathrm{n} & \end{array}$

SM 1993m1d1-2014m11d30

SM $1998 \mathrm{~m} 1 \mathrm{~d} 1-2015 \mathrm{~m} 6 \mathrm{~d} 30$

DSGE 2005q1-2014q1 $y$ y $\quad$ y

DSGE - 19941-2013

DSGE - 1978 - 20139

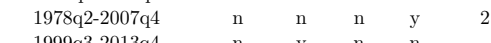

$\begin{array}{llllll}\text { DSGE } & 1999 \mathrm{q} 1-2010 \mathrm{q} 2 & \mathrm{n} & \mathrm{y} & \mathrm{n} & \mathrm{n}\end{array}$

DSGE 1989q2-2006q

$\begin{array}{ll}1990 \mathrm{q} 1-2014 \mathrm{q} \\ \mathrm{VAR} & 1994 \mathrm{q} 1-2013 \mathrm{q} \\ \mathrm{VAR} & 199 \mathrm{q} 2-207 \mathrm{q}\end{array}$

VAR 1993q2-2007q4

DSGE 1990q1-2008q

DSGE 1996q1-2008q

DSGE 1996q1-2008q

DSGE $1989 \mathrm{q} 1-2014 \mathrm{q}$

VAR $1995 q 1-2015 q$

DSGE $\quad 1994 q 1-2016 q^{3}$

DSGE 1993q1-2014q

DSGE $1999 \mathrm{q} 1-2013 \mathrm{q}$

DSGE 1996q3-2015q

DSGE 1999q1-2011q3

$1981 \mathrm{q} 2-2010 \mathrm{q}$

$1996 \mathrm{q} 2-2008 \mathrm{q}$

$1999 \mathrm{q} 1-2009 \mathrm{q} 4$

1999q1-2015q3

1983q2-2013q1

1999m1-2016m12

1998q4-2014q3

993q1-2009q3

996q4-2012q

1993q2-2013q1

1999q3-2010q3

2000q2-2012q

1990q1-2015q3

1999m1-2011m9

2003q1-2013q1

1989q1-2010q2

1993q1-2013q4

2000q1-2014q

$1980 \mathrm{q} 1-2005 \mathrm{q} 4$

980q1-2005q4

999q3-2011q3

2001q2-2016q

1982q3-2007q2

$1991 \mathrm{q} 2-2012 \mathrm{q}$

1999q1-2011q3

$1986 \mathrm{~m} 1-2008 \mathrm{~m} 11$

1983q3-2010q

1971q1-2013q

$1998 \mathrm{q} 1-2009 \mathrm{q}$

$1999 \mathrm{~m} 12-2013 \mathrm{~m} 12$

1982q4-2007q4

2001q1-2015q4

$1980 \mathrm{~m} 1-2011 \mathrm{~m} 10$

1974m3-2007m12

$1975 \mathrm{~m} 1-2007 \mathrm{~m} 12$

1999q1-2011q2

1994q3-2013q4

1983q2-2015q

$1998 \mathrm{q} 3-2010 \mathrm{q}$

2003q1-2012q

992q1-2016q

993q2-2013q1

2001q1-2014q2

1999q1-2010q2

2000q2-2011q3

2000q2-2014q

2000q2-2014q

1990q1-2007q4

1995q4-2014q4

1999q3-2010q2

1998q1-2014q4

$1995 \mathrm{q} 2-2011 \mathrm{q} 2$

$1999 \mathrm{q} 2-2014 \mathrm{q} 4$

1999q3-2008q4

VAR

1985q2-2007q4 
Table 7: Number of Monetary Policy Shock Time-Series Estimates obtained from Small Open-economy and Multi-country NK DSGE Models with and without Financial Spillovers

\begin{tabular}{|c|c|c|c|c|}
\hline & Small open-economy & Multi-country & Of which: with financial spillovers & Closed-economy \\
\hline EAR & 6 & $13(12)$ & $3(2)$ & 15 \\
\hline GBR & 6 & $3(2)$ & $2(1)$ & 3 \\
\hline USA & 0 & $8(7)$ & $3(2)$ & 18 \\
\hline Other & 60 & $28(13)$ & $17(2)$ & 14 \\
\hline
\end{tabular}

Note: The table provides the number of monetary policy shock time series estimates obtained from NK DSGE with specific model elements. The numbers in parentheses represent the frequencies without the monetary policy shock time-series estimates obtained from the model of Vitek (2015). The sum of monetary policy shock estimates obtained from NK DSGE models across economies reported in this table is smaller than that in Tables 1 and 2 because for some models there is no documentation available so that we cannot determine the model elements (see Tables 3 to 6).

Table 8: Relationship between the Monetary Policy Shock Time Series Estimates' Cross-country Correlations and Economies' International Financial Integration

\begin{tabular}{|c|c|c|c|c|c|c|c|}
\hline & $\begin{array}{c}(1) \\
\text { DSGE }\end{array}$ & $\begin{array}{c}(2) \\
\text { DSGE }\end{array}$ & $\begin{array}{c}(3) \\
\text { DSGE }\end{array}$ & $\begin{array}{c}(4) \\
\text { Non-DSGE }\end{array}$ & $\begin{array}{c}(5) \\
\text { DSGE }\end{array}$ & $\begin{array}{c}(6) \\
\text { VAR }\end{array}$ & $\begin{array}{c}(7) \\
\text { Non-DSGE/non-VAR }\end{array}$ \\
\hline Overall financial integration & $\begin{array}{c}0.09^{* * *} \\
(0.00)\end{array}$ & & $\begin{array}{c}0.08^{* * *} \\
(0.00)\end{array}$ & $\begin{array}{c}0.02 \\
(0.31)\end{array}$ & $\begin{array}{c}0.10^{* * *} \\
(0.00)\end{array}$ & $\begin{array}{c}0.01 \\
(0.82)\end{array}$ & $\begin{array}{c}0.03 \\
(0.80)\end{array}$ \\
\hline Share of US in overall financial integration & & $\begin{array}{c}0.09^{* * *} \\
(0.00)\end{array}$ & $\begin{array}{c}0.08^{* * *} \\
(0.00)\end{array}$ & $\begin{array}{c}0.00 \\
(0.89)\end{array}$ & $\begin{array}{c}0.07^{* * *} \\
(0.00)\end{array}$ & $\begin{array}{c}0.00 \\
(0.99)\end{array}$ & $\begin{array}{c}0.08 \\
(0.68)\end{array}$ \\
\hline Country 1 dummies & Yes & Yes & Yes & Yes & Yes & Yes & Yes \\
\hline Country 2 dummies & Yes & Yes & Yes & Yes & Yes & Yes & Yes \\
\hline Adj. R-squared & 0.15 & 0.15 & 0.16 & 0.03 & 0.17 & 0.05 & -0.01 \\
\hline Observations & 9214 & 8658 & 8658 & 1758 & 7360 & 1006 & 97 \\
\hline Country pairs & 171 & 153 & 153 & 120 & 120 & 120 & 45 \\
\hline
\end{tabular}

$p$-values in parentheses

${ }^{*} p<0.1,{ }^{* *} p<0.05,{ }^{* * *} p<0.01$

Table 9: Testing Additional Predictions-Role of Banking Integration

\begin{tabular}{|c|c|c|c|}
\hline & $(1)$ & $(2)$ & $(3)$ \\
\hline Overall financial integration & $\begin{array}{c}0.08^{* * *} \\
(0.00)\end{array}$ & & \\
\hline Share of US in overall financial integration & $\begin{array}{c}0.08^{\text {*** }} \\
(0.00)\end{array}$ & $\begin{array}{c}0.07^{* * *} \\
(0.00)\end{array}$ & $\begin{array}{c}0.08^{* * *} \\
(0.00)\end{array}$ \\
\hline FDI assets and liabilities/GDP & & $\begin{array}{c}0.04 \\
(0.11)\end{array}$ & $\begin{array}{c}0.03 \\
(0.20)\end{array}$ \\
\hline Portfolio assets and liabilities/GDP & & $\begin{array}{l}-0.10^{*} \\
(0.05)\end{array}$ & $\begin{array}{c}0.00 \\
(0.86)\end{array}$ \\
\hline Other inv. assets and liabilities/GDP & & $\begin{array}{c}0.32^{* * *} \\
(0.00)\end{array}$ & \\
\hline Non-resident bank loans/GDP & & & $\begin{array}{c}0.03^{* * *} \\
(0.00)\end{array}$ \\
\hline Country 1 dummies & Yes & Yes & Yes \\
\hline Country 2 dummies & Yes & Yes & Yes \\
\hline Adj. R-squared & 0.16 & 0.16 & 0.16 \\
\hline Observations & 8658 & 8658 & 8658 \\
\hline Country pairs & 153 & 153 & 153 \\
\hline
\end{tabular}


Table 10: Testing Additional Predictions-Structural Multi-country Models, Models with International Financial Frictions, and Small-open Economy Models

\begin{tabular}{|c|c|c|c|c|}
\hline & (1) & $(2)$ & $(3)$ & $(4)$ \\
\hline Overall financial integration & $\begin{array}{c}0.10^{* * *} \\
(0.00)\end{array}$ & $\begin{array}{c}0.10^{* * *} \\
(0.00)\end{array}$ & $\begin{array}{c}0.11^{* * *} \\
(0.00)\end{array}$ & $\begin{array}{c}0.11^{* * *} \\
(0.00)\end{array}$ \\
\hline Share of US in overall financial integration & $\begin{array}{c}0.09^{* * *} \\
(0.00)\end{array}$ & $\begin{array}{c}0.09^{* * *} \\
(0.00)\end{array}$ & $\begin{array}{c}0.09^{* * *} \\
(0.00)\end{array}$ & $\begin{array}{c}0.08^{* * *} \\
(0.00)\end{array}$ \\
\hline At least one multi-country model & $\begin{array}{l}-0.00 \\
(0.71)\end{array}$ & $\begin{array}{c}-0.01 \\
(0.68)\end{array}$ & $\begin{array}{l}-0.00 \\
(0.80)\end{array}$ & $\begin{array}{l}-0.01 \\
(0.61)\end{array}$ \\
\hline Over. fin. integr. $\mathrm{x}$ at least one multi-country model & & & $\begin{array}{l}-0.01 \\
(0.20)\end{array}$ & $\begin{array}{l}-0.01 \\
(0.54)\end{array}$ \\
\hline Share of US in over. fin. integr. $x$ at least one multi-country model & & & $\begin{array}{l}-0.01 \\
(0.52)\end{array}$ & $\begin{array}{l}-0.01 \\
(0.51)\end{array}$ \\
\hline At least one MC-model with fin. spillovers & & $\begin{array}{c}0.00 \\
(0.94)\end{array}$ & & $\begin{array}{c}0.01 \\
(0.51)\end{array}$ \\
\hline At least one MC-model with fin. spillovers x Overall fin. integr. & & & & $\begin{array}{c}-0.04^{* *} \\
(0.02)\end{array}$ \\
\hline At least one MC-model with fin. spillovers $x$ Share of US in overall fin. integr. & & & & $\begin{array}{c}0.03 \\
(0.15)\end{array}$ \\
\hline At least one SOE model & $\begin{array}{l}-0.00 \\
(0.77)\end{array}$ & $\begin{array}{c}-0.01 \\
(0.60)\end{array}$ & $\begin{array}{l}-0.00 \\
(0.86)\end{array}$ & $\begin{array}{l}-0.00 \\
(0.78)\end{array}$ \\
\hline Over. fin. integr. $\mathrm{x}$ at least one SOE model & & & $\begin{array}{l}-0.00 \\
(0.63)\end{array}$ & $\begin{array}{l}-0.00 \\
(0.83)\end{array}$ \\
\hline Share of US in over. fin. integr. $x$ at least one SOE model & & & $\begin{array}{c}0.01 \\
(0.51)\end{array}$ & $\begin{array}{c}0.01 \\
(0.32)\end{array}$ \\
\hline At least one SOE model with fin. spillovers & & $\begin{array}{c}0.01 \\
(0.46)\end{array}$ & & $\begin{array}{c}0.01 \\
(0.45)\end{array}$ \\
\hline At least one SOE model with fin. spillovers x Overall fin. integr. & & & & $\begin{array}{l}-0.02 \\
(0.12)\end{array}$ \\
\hline At least one SOE model with fin. spillovers $x$ Share of US in overall fin. integr & & & & $\begin{array}{c}-0.07^{* * *} \\
(0.00)\end{array}$ \\
\hline Country 1 dummies & Yes & Yes & Yes & Yes \\
\hline Country 2 dummies & Yes & Yes & Yes & Yes \\
\hline Adj. R-squared & 0.16 & 0.16 & 0.16 & 0.16 \\
\hline Observations & 6101 & 6017 & 6017 & 6017 \\
\hline Country pairs & 153 & 153 & 153 & 153 \\
\hline
\end{tabular}

$p$-values in parentheses

${ }^{*} p<0.1,{ }^{* *} p<0.05,{ }^{* * *} p<0.01$ 
Table 11: Testing Additional Predictions - Capital Controls and Exchange Rate Flexibility

\begin{tabular}{|c|c|c|c|}
\hline & $(1)$ & $(2)$ & (3) \\
\hline Overall financial integration & $\begin{array}{c}0.083^{* * *} \\
(0.000)\end{array}$ & $\begin{array}{c}0.076^{* * *} \\
(0.000)\end{array}$ & $\begin{array}{c}0.072^{* * *} \\
(0.004)\end{array}$ \\
\hline Share of US in overall financial integration & $\begin{array}{c}0.079^{* * *} \\
(0.000)\end{array}$ & $\begin{array}{c}0.079^{* * *} \\
(0.000)\end{array}$ & $\begin{array}{c}0.079^{* * *} \\
(0.000)\end{array}$ \\
\hline Capital controls (PC) & & $\begin{array}{c}0.006 \\
(0.550)\end{array}$ & $\begin{array}{l}0.053^{*} \\
(0.099)\end{array}$ \\
\hline FX flexibility & & $\begin{array}{c}-0.015 \\
(0.795)\end{array}$ & $\begin{array}{c}0.009 \\
(0.868)\end{array}$ \\
\hline Capital controls x At least one economy is EME & & & $\begin{array}{c}-0.053 \\
(0.106)\end{array}$ \\
\hline FX flexibility $\mathrm{x}$ At least one economy is EME & & & $\begin{array}{c}-0.041 \\
(0.177)\end{array}$ \\
\hline At least one economy is EME & & & $\begin{array}{c}0.058 \\
(0.320)\end{array}$ \\
\hline Country 1 dummies & Yes & Yes & Yes \\
\hline Country 2 dummies & Yes & Yes & Yes \\
\hline Adj. R-squared & 0.16 & 0.16 & 0.16 \\
\hline Observations & 8658 & 8658 & 8658 \\
\hline Country pairs & 153 & 153 & 153 \\
\hline
\end{tabular}

Table 12: Robustness Checks-Alternative Explanations I

\begin{tabular}{lccccc}
\hline \hline & $(1)$ & $(2)$ & $(3)$ & $(4)$ & $(5)$ \\
\hline Overall financial integration & $0.08^{* * *}$ & $0.08^{* * *}$ & $0.06^{* *}$ & $0.06^{* * *}$ & $0.06^{* *}$ \\
& $(0.00)$ & $(0.00)$ & $(0.01)$ & $(0.00)$ & $(0.02)$ \\
& & & & & \\
Share of US in overall financial integration & $0.08^{* * *}$ & $0.08^{* * *}$ & $0.08^{* * *}$ & $0.07^{* * *}$ & $0.08^{* * *}$ \\
& $(0.00)$ & $(0.00)$ & $(0.00)$ & $(0.00)$ & $(0.00)$ \\
& & 0.02 & & & 0.02 \\
Trade integration & & $(0.38)$ & & & $(0.37)$ \\
& & -0.00 & & & -0.00 \\
Share of US in trade integration & & $(0.78)$ & & & $0.70)$ \\
& & & $0.01^{* * *}$ & & 0.01 \\
Bilateral financial integration & & & $(0.00)$ & & $(0.37)$ \\
& & & & $0.01^{* *}$ & 0.00 \\
Bilateral trade integration & & & & $(0.03)$ & $(0.77)$ \\
& & & & & \\
Country 1 dummies & Yes & Yes & Yes & Yes & Yes \\
Country 2 dummies & Yes & Yes & Yes & Yes & Yes \\
\hline Adj. R-squared & 0.16 & 0.16 & 0.16 & 0.16 & 0.16 \\
Observations & 8658 & 8658 & 8658 & 8658 & 8658 \\
Country pairs & 153 & 153 & 153 & 153 & 153 \\
\hline \hline$p$-values in parentheses & & & & & \\
${ }^{*} p<0.1,{ }^{* *} p<0.05,{ }^{* * *} p<0.01$ & & & & &
\end{tabular}


Table 13: Robustness Checks-Alternative Explanations II

\begin{tabular}{|c|c|c|c|c|c|c|}
\hline & (1) & $(2)$ & (3) & (4) & (5) & (6) \\
\hline Overall financial integration & $\begin{array}{c}0.08^{* * *} \\
(0.00)\end{array}$ & $\begin{array}{c}0.10^{* * *} \\
(0.00)\end{array}$ & $\begin{array}{c}0.08^{* * *} \\
(0.00)\end{array}$ & $\begin{array}{c}0.08^{* * *} \\
(0.00)\end{array}$ & $\begin{array}{c}0.08^{* * *} \\
(0.00)\end{array}$ & $\begin{array}{c}0.09^{* * *} \\
(0.00)\end{array}$ \\
\hline Share of US in overall financial integration & $\begin{array}{c}0.08^{* * *} \\
(0.00)\end{array}$ & $\begin{array}{c}0.08^{* * *} \\
(0.00)\end{array}$ & $\begin{array}{c}0.08^{* * *} \\
(0.00)\end{array}$ & $\begin{array}{c}0.08^{* * *} \\
(0.00)\end{array}$ & $\begin{array}{c}0.07^{* * *} \\
(0.00)\end{array}$ & $\begin{array}{c}0.07^{* * *} \\
(0.00)\end{array}$ \\
\hline Foreign currency net short position & & $\begin{array}{l}-0.02 \\
(0.15)\end{array}$ & & & & $\begin{array}{c}-0.02 \\
(0.22)\end{array}$ \\
\hline At least one model with open-economy variables in Taylor rule & & & $\begin{array}{c}0.00 \\
(0.69)\end{array}$ & & & $\begin{array}{c}0.00 \\
(0.67)\end{array}$ \\
\hline Ratio of fuel/ore/metals exports to GDP & & & & $\begin{array}{c}0.01 \\
(0.33)\end{array}$ & & $\begin{array}{c}-0.00 \\
(0.82)\end{array}$ \\
\hline Ratio of fuel/ore/metals imports to GDP & & & & $\begin{array}{c}-0.02 \\
(0.20)\end{array}$ & & $\begin{array}{c}-0.02 \\
(0.14)\end{array}$ \\
\hline Both commodity exporters & & & & & $\begin{array}{l}0.05^{*} \\
(0.06)\end{array}$ & $\begin{array}{c}0.08 \\
(0.12)\end{array}$ \\
\hline Country 1 dummies & Yes & Yes & Yes & Yes & Yes & Yes \\
\hline Country 2 dummies & Yes & Yes & Yes & Yes & Yes & Yes \\
\hline Adj. R-squared & 0.16 & 0.16 & 0.16 & 0.16 & 0.16 & 0.16 \\
\hline Observations & 8658 & 8658 & 7911 & 8658 & 8658 & 7911 \\
\hline Country pairs & 153 & 153 & 153 & 153 & 153 & 153 \\
\hline
\end{tabular}

$p$-values in parentheses

${ }^{*} p<0.1,{ }^{* *} p<0.05,{ }^{* * *} p<0.01$ 
Table 14: Robustness Checks-Alternative Explanations III

\begin{tabular}{|c|c|c|c|c|c|c|c|c|c|}
\hline & (1) & (2) & (3) & (4) & (5) & (6) & (7) & (8) & (9) \\
\hline Overall financial integration & $\begin{array}{c}0.08^{* * *} \\
(0.00)\end{array}$ & $\begin{array}{c}0.08^{* * *} \\
(0.00)\end{array}$ & $\begin{array}{c}0.08^{* * *} \\
(0.00)\end{array}$ & $\begin{array}{c}0.08^{* * *} \\
(0.00)\end{array}$ & $\begin{array}{c}0.07^{* * *} \\
(0.00)\end{array}$ & $\begin{array}{c}0.09^{* * *} \\
(0.00)\end{array}$ & $\begin{array}{c}0.08^{* * *} \\
(0.00)\end{array}$ & $\begin{array}{c}0.09^{* * *} \\
(0.00)\end{array}$ & $\begin{array}{c}0.07^{* * * *} \\
(0.00)\end{array}$ \\
\hline Share of US in overall financial integration & $\begin{array}{c}0.08^{* * *} \\
(0.00)\end{array}$ & $\begin{array}{c}0.08^{* * *} \\
(0.00)\end{array}$ & $\begin{array}{c}0.08^{* * *} \\
(0.00)\end{array}$ & $\begin{array}{c}0.10^{* * *} \\
(0.00)\end{array}$ & $\begin{array}{c}0.09^{* * *} \\
(0.00)\end{array}$ & $\begin{array}{c}0.10^{* * *} \\
(0.00)\end{array}$ & $\begin{array}{c}0.10^{* * *} \\
(0.00)\end{array}$ & $\begin{array}{c}0.10^{* * *} \\
(0.00)\end{array}$ & $\begin{array}{c}0.10^{* * *} \\
(0.00)\end{array}$ \\
\hline Difference in trade integration & & $\begin{array}{l}-0.01 \\
(0.18)\end{array}$ & & & & & & & $\begin{array}{l}-0.01 \\
(0.23)\end{array}$ \\
\hline Difference in centrality & & & $\begin{array}{l}-0.00 \\
(0.48)\end{array}$ & & & & & & $\begin{array}{l}-0.01 \\
(0.12)\end{array}$ \\
\hline Difference in GVC position & & & & $\begin{array}{c}0.00 \\
(0.64)\end{array}$ & & & & & $\begin{array}{c}0.01 \\
(0.44)\end{array}$ \\
\hline Difference in GVC participation & & & & & $\begin{array}{l}-0.01 \\
(0.28)\end{array}$ & & & & $\begin{array}{l}-0.01 \\
(0.47)\end{array}$ \\
\hline Heterogeneity in output structure & & & & & & $\begin{array}{c}0.01 \\
(0.44)\end{array}$ & & & $\begin{array}{c}0.01 \\
(0.54)\end{array}$ \\
\hline Heterogeneity in export structure & & & & & & & $\begin{array}{c}0.01 \\
(0.30)\end{array}$ & & $\begin{array}{c}0.01 \\
(0.27)\end{array}$ \\
\hline Heterogeneity in import structure & & & & & & & & $\begin{array}{c}0.01 \\
(0.58)\end{array}$ & $\begin{array}{c}0.00 \\
(0.81)\end{array}$ \\
\hline Country 1 dummies & Yes & Yes & Yes & Yes & Yes & Yes & Yes & Yes & Yes \\
\hline Country 2 dummies & Yes & Yes & Yes & Yes & Yes & Yes & Yes & Yes & Yes \\
\hline Adj. R-squared & 0.16 & 0.16 & 0.16 & 0.16 & 0.16 & 0.16 & 0.16 & 0.16 & 0.16 \\
\hline Observations & 8658 & 8658 & 8658 & 8250 & 8250 & 8250 & 8250 & 8250 & 8250 \\
\hline Country pairs & 153 & 153 & 153 & 136 & 136 & 136 & 136 & 136 & 136 \\
\hline
\end{tabular}

Table 15: Robustness Checks-Alternative Samples

\begin{tabular}{lccccc}
\hline \hline & $(1)$ & $(2)$ & $(3)$ & $(4)$ & $(5)$ \\
& Baseline & CBs/IOs & w/o Vitek & Max. sample & Public \\
\hline Overall financial integration & $0.08^{* * *}$ & $0.12^{*}$ & $0.10^{* * *}$ & $0.06^{* * *}$ & $0.07^{* * *}$ \\
& $(0.00)$ & $(0.06)$ & $(0.00)$ & $(0.00)$ & $(0.00)$ \\
Share of US in overall financial integration & $0.08^{* * *}$ & $0.13^{* * *}$ & $0.10^{* * *}$ & $0.07^{* * *}$ & $0.08^{* * *}$ \\
& $(0.00)$ & $(0.00)$ & $(0.00)$ & $(0.00)$ & $(0.00)$ \\
& & & & & \\
Country 1 dummies & Yes & Yes & Yes & Yes & Yes \\
Country 2 dummies & Yes & Yes & Yes & Yes & Yes \\
\hline Adj. R-squared & 0.16 & 0.30 & 0.16 & 0.15 & 0.15 \\
Observations & 8658 & 258 & 6448 & 10555 & 7298 \\
Country pairs & 153 & 120 & 153 & 325 & 153 \\
\hline \hline$p$-values in parentheses & & & & & \\
${ }^{*} p<0.1,{ }^{* *} p<0.05,{ }^{* * *} p<0.01$ & & & & &
\end{tabular}


Table 16: Robustness Checks-Published Papers

\begin{tabular}{lcccc}
\hline \hline & $(1)$ & $(2)$ & $(3)$ & $(4)$ \\
& Baseline & Published & Keele>1 & Keele>2 \\
\hline Overall financial integration & $0.08^{* * *}$ & $0.07^{* * *}$ & $0.05^{*}$ & 0.11 \\
& $(0.00)$ & $(0.00)$ & $(0.08)$ & $(0.27)$ \\
Share of US in overall financial integration & $0.08^{* * *}$ & $0.10^{* * *}$ & $0.12^{* * *}$ & $0.16^{*}$ \\
& $(0.00)$ & $(0.01)$ & $(0.00)$ & $(0.08)$ \\
& & & & \\
Country 1 dummies & Yes & Yes & Yes & Yes \\
Country 2 dummies & Yes & Yes & Yes & Yes \\
\hline Adj. R-squared & 0.16 & 0.17 & 0.18 & 0.24 \\
Observations & 8658 & 1963 & 666 & 149 \\
Country pairs & 153 & 105 & 66 & 28 \\
\hline \hline
\end{tabular}

$p$-values in parentheses

${ }^{*} p<0.1,{ }^{* *} p<0.05,{ }^{* * *} p<0.01$

Table 17: Robustness Checks-Alternative Model Specifications

\begin{tabular}{|c|c|c|c|c|c|c|c|c|}
\hline & $\begin{array}{c}(1) \\
\text { Baseline }\end{array}$ & $\begin{array}{c}(2) \\
\text { Insign. }=0\end{array}$ & $\begin{array}{c}(3) \\
\text { Logit }\end{array}$ & $\begin{array}{c}(4) \\
\text { Tobit }\end{array}$ & $\begin{array}{l}(5) \\
\mathrm{FE}\end{array}$ & $\begin{array}{l}(6) \\
\text { rreg }\end{array}$ & $\begin{array}{l}(7) \\
\text { Min. }\end{array}$ & $\begin{array}{c}(8) \\
\text { Collapsed }\end{array}$ \\
\hline Overall financial integration & $\begin{array}{c}0.08^{* * *} \\
(0.00)\end{array}$ & $\begin{array}{c}0.06^{* * *} \\
(0.00)\end{array}$ & $\begin{array}{c}0.18^{* * *} \\
(0.00)\end{array}$ & $\begin{array}{c}0.08^{* * *} \\
(0.00)\end{array}$ & $\begin{array}{c}0.08^{* * *} \\
(0.00)\end{array}$ & $\begin{array}{c}0.09^{* * *} \\
(0.00)\end{array}$ & $\begin{array}{c}0.08^{* * *} \\
(0.00)\end{array}$ & $\begin{array}{c}0.03^{* * *} \\
(0.00)\end{array}$ \\
\hline Share of US in overall financial integration & $\begin{array}{c}0.08^{* * *} \\
(0.00)\end{array}$ & $\begin{array}{c}0.06^{* * *} \\
(0.00)\end{array}$ & $\begin{array}{c}0.17^{* * *} \\
(0.00)\end{array}$ & $\begin{array}{c}0.08^{* * *} \\
(0.00)\end{array}$ & $\begin{array}{c}0.08^{* * *} \\
(0.00)\end{array}$ & $\begin{array}{c}0.08^{* * *} \\
(0.00)\end{array}$ & $\begin{array}{c}0.08^{* * *} \\
(0.00)\end{array}$ & $\begin{array}{c}0.01 \\
(0.12)\end{array}$ \\
\hline Country 1 dummies & Yes & Yes & Yes & Yes & No & Yes & Yes & No \\
\hline Country 2 dummies & Yes & Yes & Yes & Yes & No & Yes & Yes & No \\
\hline Country-shock 1 dummies & No & No & No & No & Yes & No & No & No \\
\hline Country-shock 2 dummies & No & No & No & No & Yes & No & No & No \\
\hline Adj. R-squared & 0.16 & 0.12 & 0.16 & & 0.28 & 0.15 & 0.16 & 0.05 \\
\hline Observations & 8658 & 8658 & 8658 & 8658 & 8658 & 8658 & 8658 & 153 \\
\hline Country pairs & 153 & 153 & 153 & & 153 & & 153 & \\
\hline
\end{tabular}

$p$-values in parentheses

${ }^{*} p<0.1,{ }^{* *} p<0.05,{ }^{* * *} p<0.01$

Table 18: Robustness Checks-US vs. Euro Area as Core Economy

\begin{tabular}{lccc}
\hline \hline & $(1)$ & $(2)$ & $(3)$ \\
& Baseline & US+EA core & Regional core \\
\hline Overall financial integration & $0.08^{* * *}$ & $0.06^{* * *}$ & $0.06^{* *}$ \\
& $(0.00)$ & $(0.00)$ & $(0.01)$ \\
Share of US in overall financial integration & $0.08^{* * *}$ & 0.04 & 0.00 \\
& $(0.00)$ & $(0.12)$ & $(0.94)$ \\
Share of EA in overall financial integration & & & -0.03 \\
& & & $(0.04$ \\
& & & $0.19)$ \\
Share of regional core in overall financial integration & & & $(0.01)$ \\
& & & Yes \\
Country 1 dummies & Yes & Yes & Yes \\
Country 2 dummies & & & 0.11 \\
\hline Adj. R-squared & Yes & Yes & 5022 \\
Observations & 0.16 & 0.10 & 136 \\
Country pairs & 8658 & 5022 & \\
\hline \hline$p$-values in parentheses & 153 & 136 & \\
${ }^{*} p<0.1,{ }^{* *} p<0.05,{ }^{* * *} p<0.01$ & & & \\
\hline
\end{tabular}




\section{B Figures}

Figure 1: Distribution of Correlation between Smoothed Monetary Policy Shocks for the Euro Area and Japan across Replications in the Monte Carlo Experiment

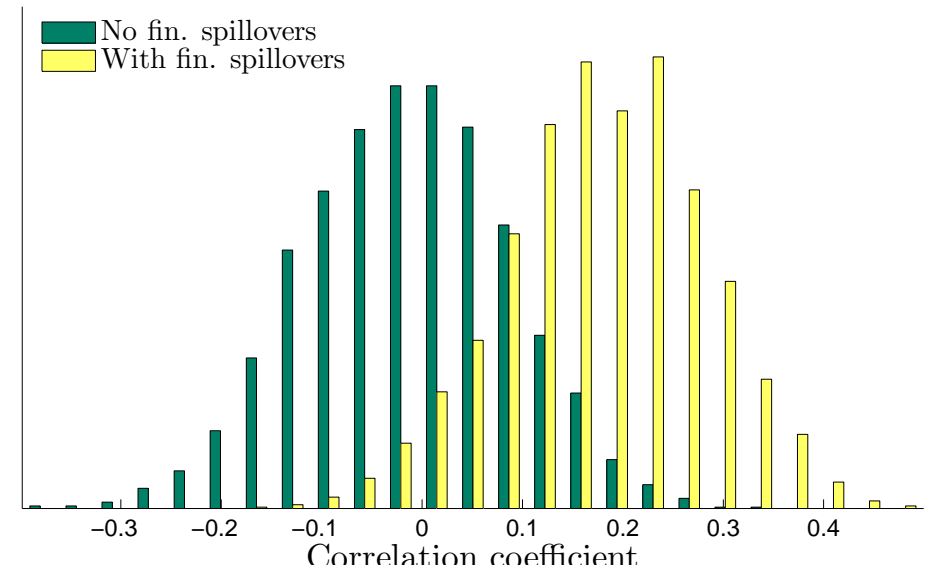

Note: The figure shows the distribution of the correlations between the smoothed monetary policy shocks for the non-core economies of the euro area and Japan across the 1,000 replications of the Monte Carlo experiment. The smoothed monetary policy shocks are obtained from applying the Kalman-filter with the corresponding single-country models on the data simulated based on the multi-country data-generating process. The dark green bars refer to the distribution of the cross-country correlations under the "no financial spillover" parametrisation of the datagenerating process, and the light yellow bars to the distribution of the cross-country correlations under the "financial spillover" parametrisation. 
Figure 2: Distribution of Coefficient Estimates in the Regression of Estimated Euro Area Monetary Policy Shocks on the True Shocks Across Replications of the Monte Carlo Experiment
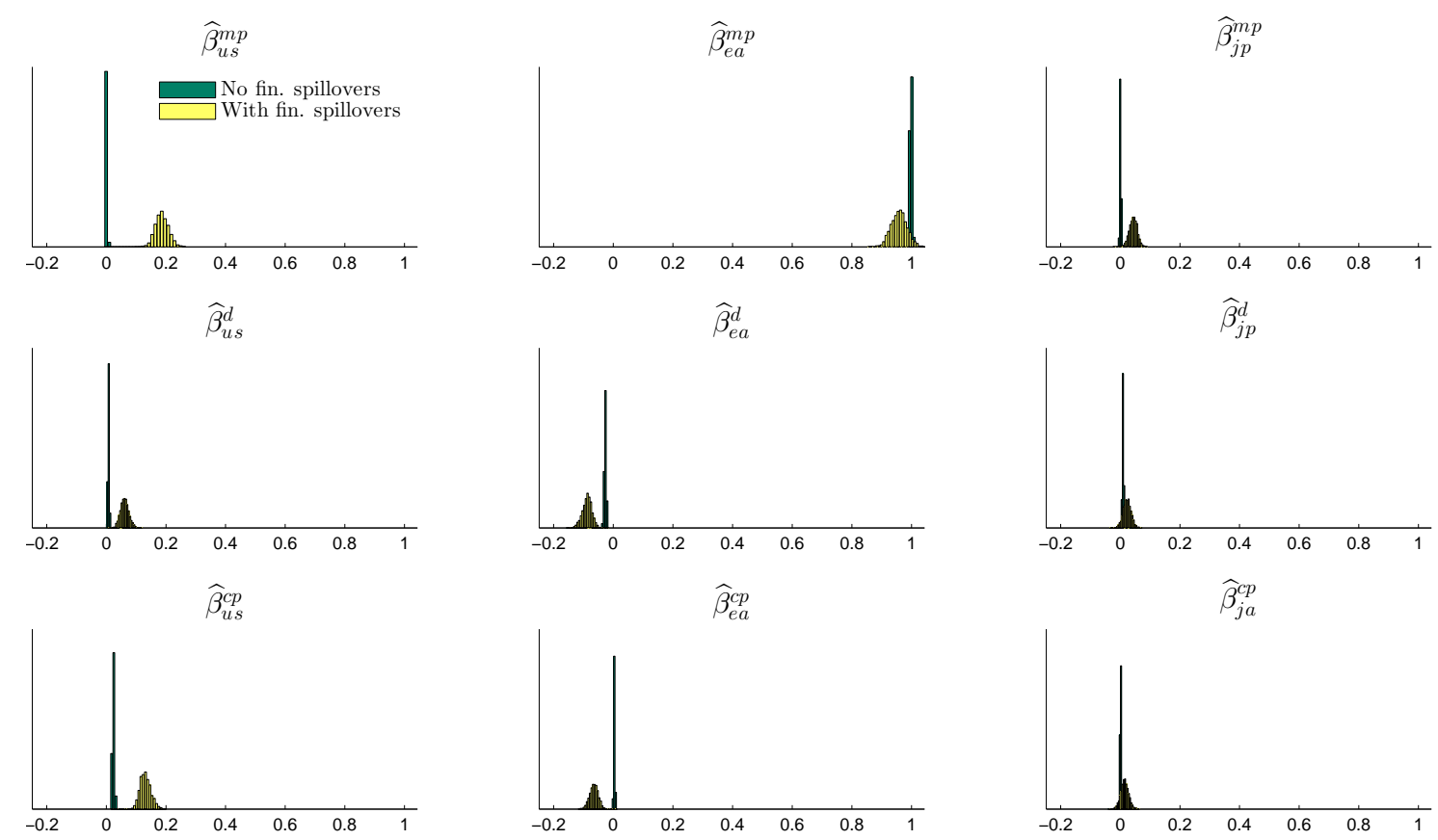

Note: The figure displays the distribution of the coefficient estimates in the regression of Equation (2).

Figure 3: True and Local Projection Spillover Estimates for Euro Area Monetary Policy Shocks to the US in the Monte Carlo Experiment
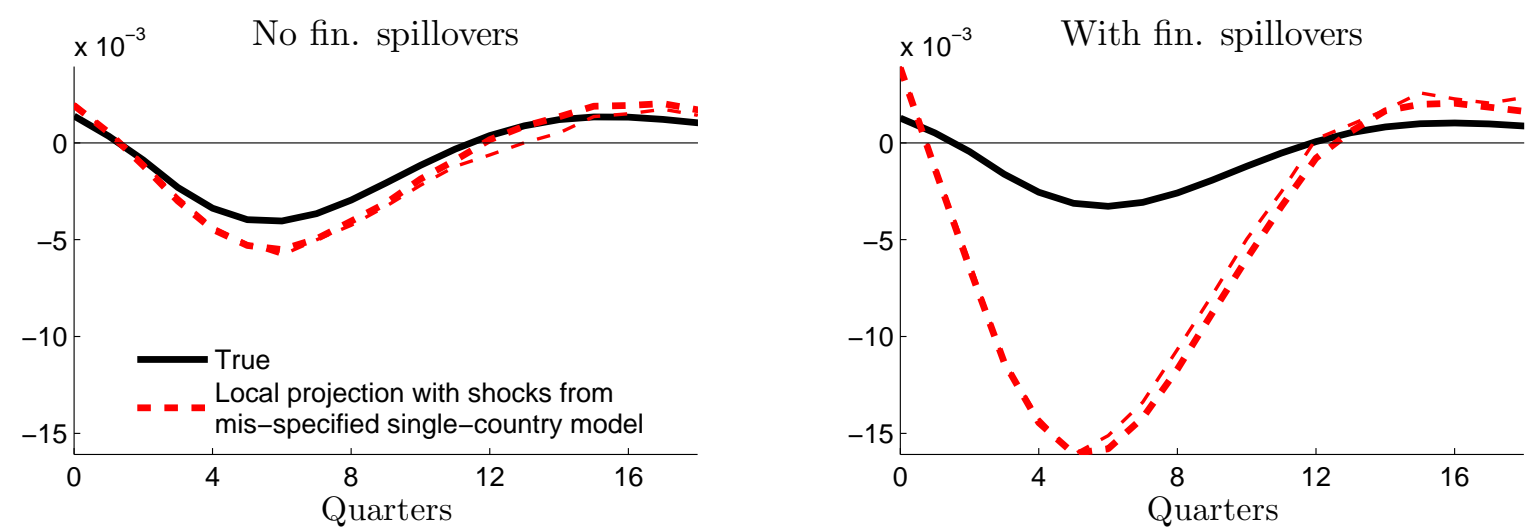

Note: The figure shows the spillovers from a euro area monetary policy shock to the US output gap. The black solid line represents the true value of the spillover implied by the multi-country model of Coenen and Wieland (2002), and the thick (thin) red dashed line the average (median) spillover estimate across all replications of the Monte Carlo experiment. The left-hand side panel displays the spillovers for the "no financial spillover" parametrisation, and the right-hand side panel under the "financial spillover" parametrisation. The spillover estimates are obtained using the smoothed monetary policy shocks and data on the US output gap in local projections. In each replication of the Monte Carlo experiment, the smoothed monetary policy shocks are obtained applying the Kalman-filter with the corresponding single-country models on the data simulated based on the multi-country data-generating process. The US output gap data stem from the corresponding simulations of the multi-country data-generating process. 


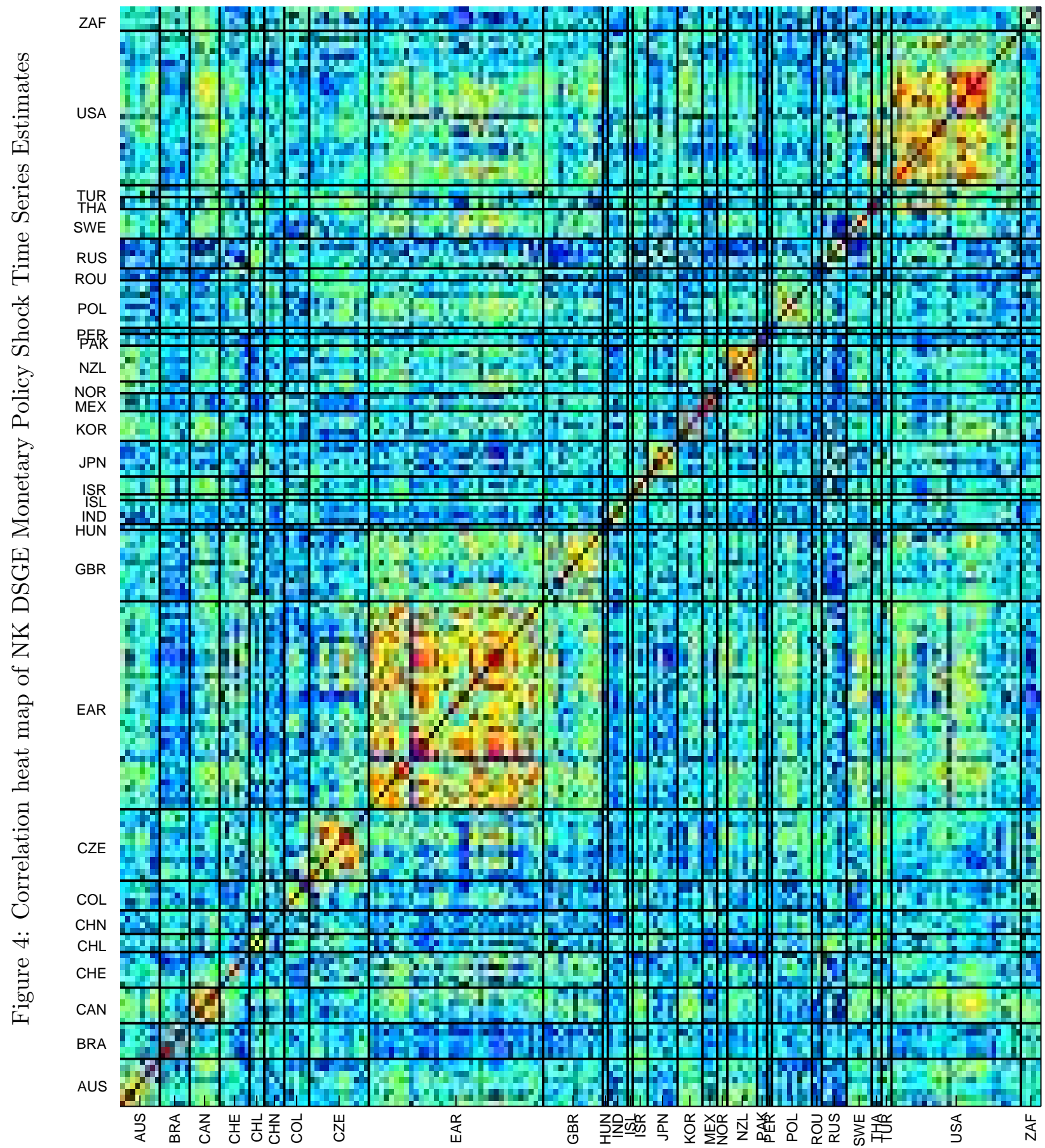


Figure 5: Distribution of Cross-country Correlations Between Monetary Policy Shock Time Series Estimates

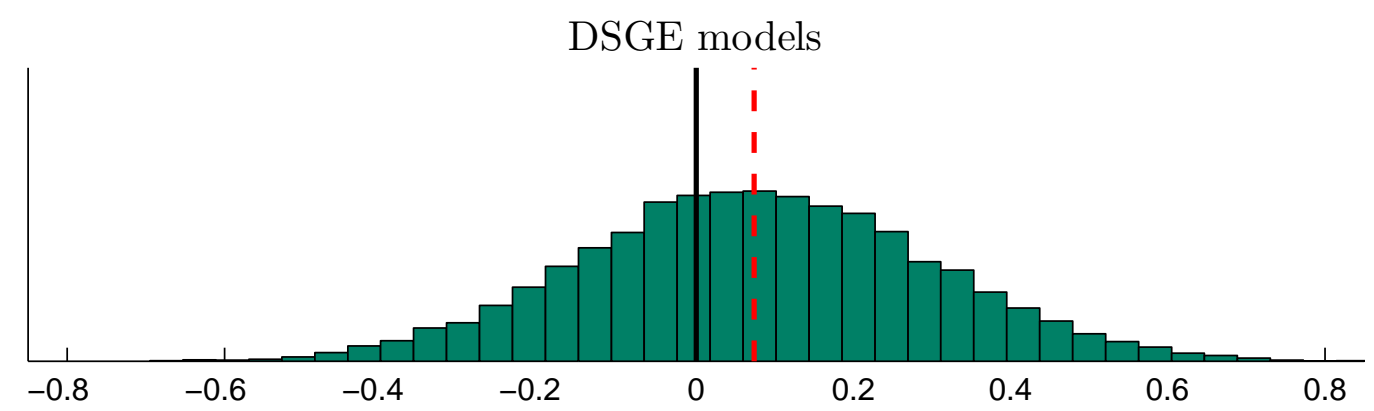

Non-DSGE models

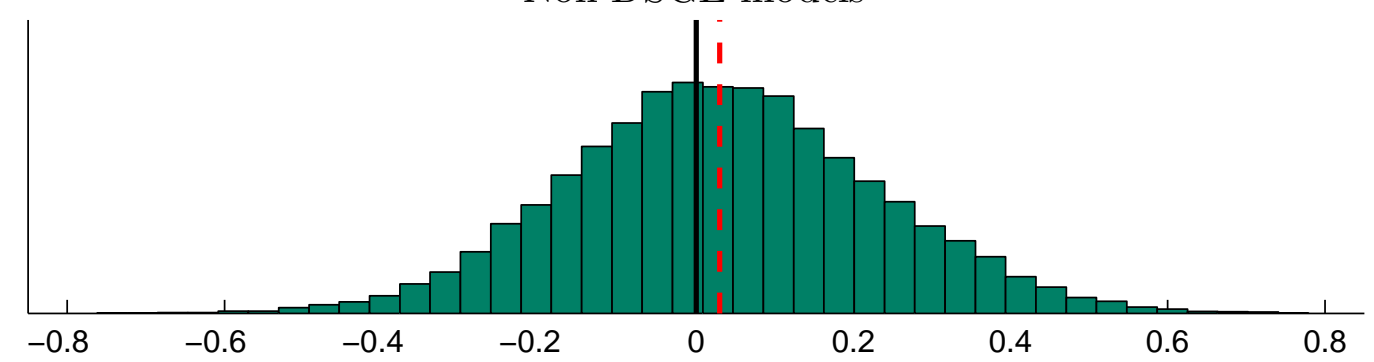

DSGE models for AEs

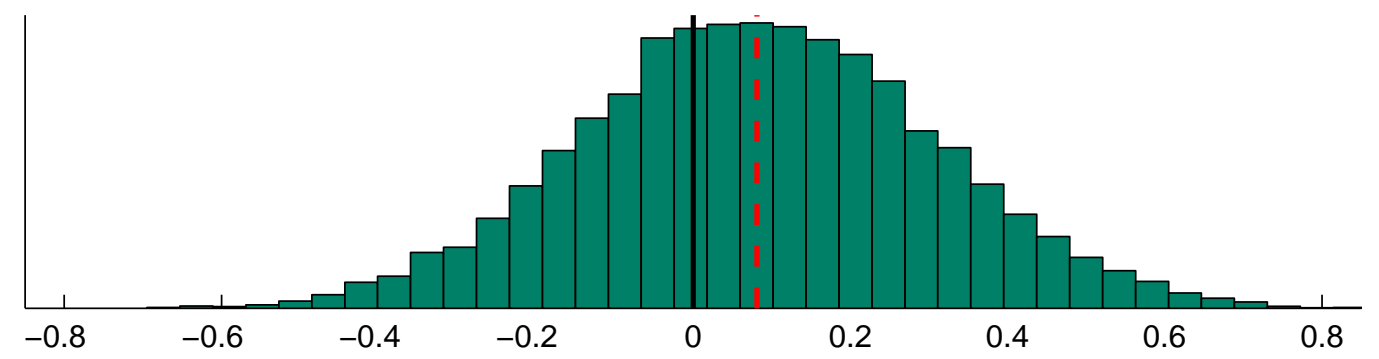

DSGE models for financially integrated economies

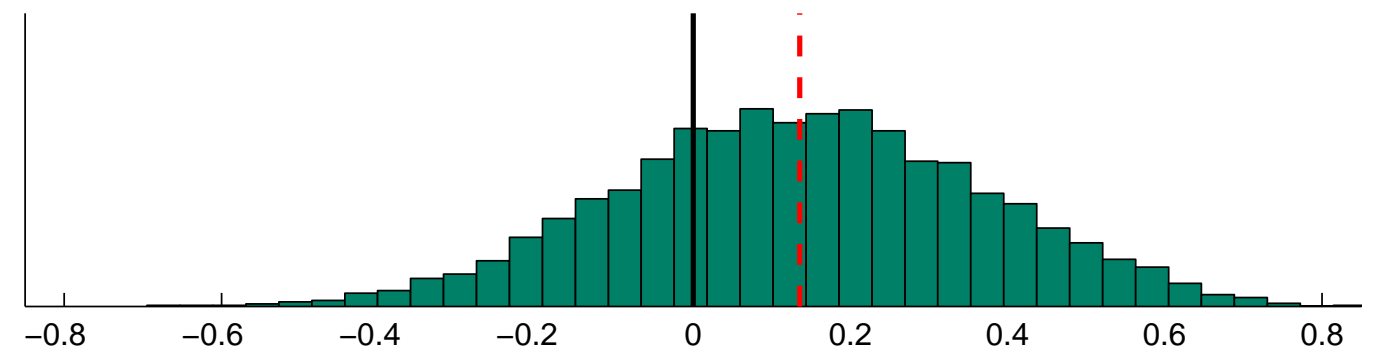

Note: The figure displays the distributions of the cross-country correlations between the monetary policy shock time series estimates in our database. The red dashed lines indicate the mean of the distributions. 
Figure 6: Estimates of Global Output Spillovers from Monetary Policy based on Local Projections and Monetary Policy Shock Estimates from DSGE Models and Non-DSGE

Approaches
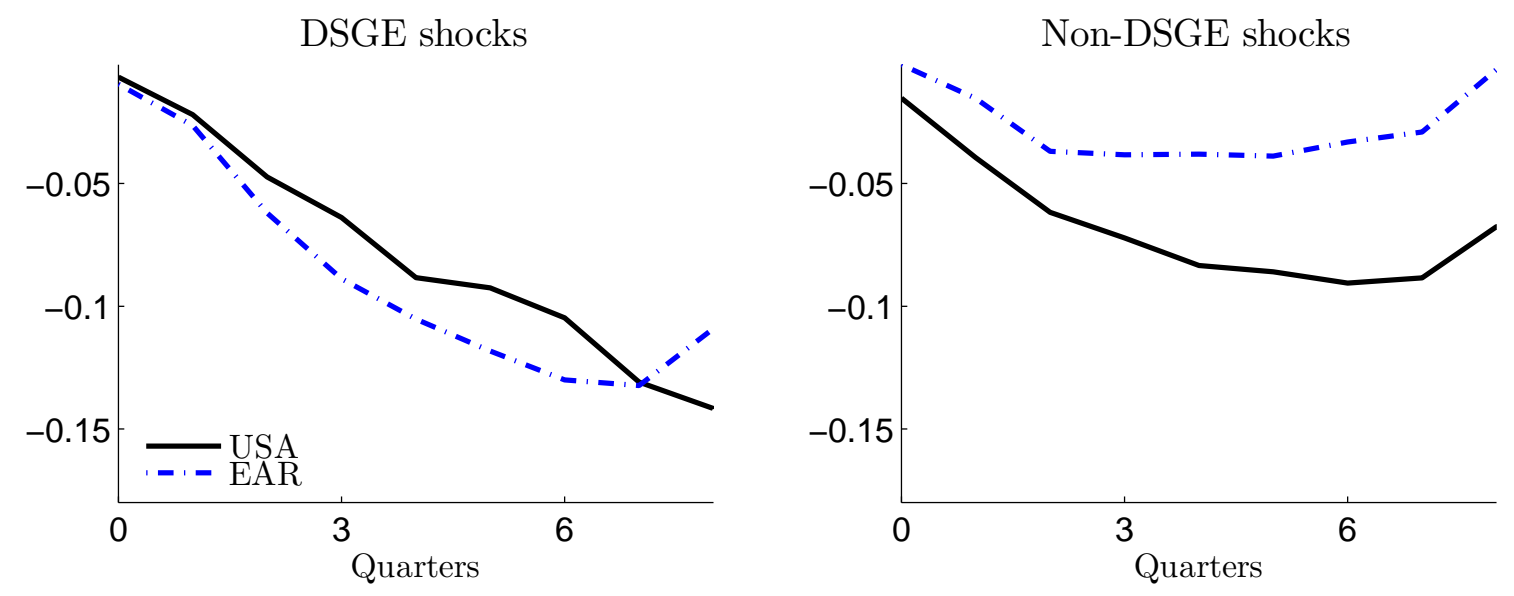

Note: The figure shows the cross-country averages of the estimates of the spillovers from US (black solid line) and the euro area (blue dash-dotted line) monetary policy to global output. The spillovers are estimated using local projections with the first principal component of all monetary policy shock estimates available over the time period 1993 to 2007 for the US and the euro area. The left-hand side panel displays the spillover estimates for the case when only DSGE model monetary policy shocks are used to determine the principal component, and the right-hand side panel for the case when only non-DSGE model shocks are used. 


\section{Online Appendix}

\section{C.1 Construction of monetary policy shocks based on Consensus Forecast data}

We use monthly data on three-month ahead financial market expectations about of shortterm interest rates from Consensus Economics in order to form monetary policy shock time series. To identify the benchmark interest rate to use for the construction of monetary policy surprise series we follow closely the target interest rate for the surveyed financial institutions as reported by Consensus Economics and change the benchmark according to changes reported. For the US we first subtract from the actual realised short-term interest rate onequarter lagged, three-month ahead Consensus Forecast short-term interest rate expectation. We then regress the resulting difference on four lags of the log-difference of US industrial production and the consumer price index. The residual from this regression in our time series of US monetary policy shocks constructed based on Consensus Forecast data. For the time period from 2003 onwards, we additionally regress this time series of residuals on CitiGroup macroeconomic surprises, and use the residuals from this regression as US monetary policy shocks. For the euro area and the UK, in the first regression in addition to domestic variables we also include US industrial production and inflation. For the euro area, prior to January 2005, when a euro area survey was established, the financial-market expectations are a weighted average of the euro area countries' data. From January 1990 through December 1998, the euro area average was weighted by GDP at purchasing power parities. From January 1999 onwards the euro area average was weighted by the nominal stock of government bonds.

\section{C.2 The Model of Coenen and Wieland (2002)}

\section{C.2.1 Model description}

For $i \in\{u s, e a, j a\}$, the IS-curve for the domestic output gap $q_{i t}$ is given by

$$
q_{i t}=\sum_{j=1}^{3} \delta_{i j}^{q} q_{i, t-j}+\delta_{i}^{z} z_{i t}+\delta_{i}^{r l}\left(r_{i, t-1}^{(l)}-\bar{r}_{i}^{(l)}\right)+\sigma^{e^{d}} e_{i t}^{d},
$$

where $z_{i t}=\sum_{j=1, j \neq i}^{N} w_{i j} \cdot \omega_{i j, t}$ is an economy's real effective exchange rate with $w_{i j}$ representing bilateral trade shares and $\omega_{i j, t}$ bilateral exchange rates; $r_{i t}^{(l)}$ is the real long-term interest rate; and $e_{i t}^{d}$ is a demand shock. Quarter-on-quarter inflation is determined in a 
backward-looking Phillips-curve

$$
\pi_{i t}=\left(\sum_{j=1}^{3} \phi_{j i}\right)^{-1}\left(\sum_{j=0}^{3} \phi_{j i} c w p_{i, t-j}-\left(\phi_{2 i}+\phi_{3 i}\right) \pi_{i, t-1}-\phi_{3 i} \pi_{i, t-2}\right),
$$

where $c w p_{i t}$ is the contract wage. Based on specification tests Coenen and Wieland (2002) consider fixed-duration Taylor-style wage contracts for the euro area and Japan

$$
\begin{aligned}
c w p_{i t}= & \left(\phi_{1 i}+\phi_{2 i}+\phi_{3 i}\right) E_{t} \pi_{i, t+1}+\left(\phi_{2 i}+\phi_{3 i}\right) E_{t} \pi_{i, t+2}+\phi_{3 i} E_{t} \pi_{i, t+3} \\
& +\gamma_{i} \sum_{j=0}^{3} \phi_{j i} E_{t} q_{i, t+j}+\sigma_{i}^{c w} e_{i t}^{c w}, \quad i \in\{e a, j a\},
\end{aligned}
$$

and relative real wage contracts for the US

$$
\begin{aligned}
c w p_{u s, t} & =\sum_{j=0}^{3} \phi_{j, u s} E_{t} \varpi_{u s, t+j}+\gamma_{u s} \sum_{j=0}^{3} \phi_{j, u s} E_{t} q_{u s, t+j}+\sigma_{u s}^{c w} e_{u s, t}^{c w}, \\
\varpi_{u s, t} & =\sum_{j=0}^{3} \phi_{j, u s} c w p_{u s, t-j} .
\end{aligned}
$$

The model is closed by monetary policy rules which determine the nominal short-term interest rate $i_{i t}^{(s)}$ according to

$$
i_{i t}^{(s)}=\rho_{i s} i_{i, t-1}^{(s)}+\alpha_{i}\left(\pi_{i t}^{(4)}-\pi_{i}^{T}\right)+\beta_{i} q_{i t}+\left(1-\rho_{i}\right)\left(\bar{r}_{i}^{(l)}+\pi_{i t}^{(4)}\right)+\sigma_{i}^{i^{s}} e_{i t}^{m p},
$$

where $\pi_{i}^{T}$ represents the inflation target, and $e_{i t}^{m p}$ is a monetary policy shock. Year-on-year inflation $\pi_{i t}^{(4)}$ is given by

$$
\pi_{i t}^{(4)}=\sum_{j=0}^{3} \pi_{i, t-j}
$$

The real long-term interest rate is defined as

$$
r_{i t}^{(l)}=i_{i t}^{(l)}-\frac{1}{8} \sum_{j=1}^{8} E_{t} \pi_{i, t+j}
$$

Finally, the uncovered interest rate parity condition is given by

$$
\omega_{i, u s, t}=E_{t} \omega_{i, u s, t+1}+4 \cdot E_{t} \pi_{i, t+1}-i_{i t}^{(l)}+i_{u s, t}^{(l)}-4 \cdot E_{t} \pi_{u s, t+1}
$$




\section{C.2.2 Responses of domestic and foreign variables to monetary policy shocks}

Figure 7 displays the responses of the US and the euro area to a contractionary monetary policy shock in the US. The impulse responses under the "no financial spillovers" scenario are depicted by the solid lines, and those under the "financial spillovers" scenario by the dashed lines. While the domestic responses in the US economy are rather similar under the two scenarios, the spillovers to output and inflation in the euro area from a monetary policy shock abroad are substantially larger in the "financial spillovers" scenario. In particular, under the "no financial spillovers" scenario the spillovers are small and expansionary as those arising through trade dominate: The euro depreciates in response to a monetary policy tightening in the US, stimulating the euro area's net exports through expenditure switching. In contrast, under the "financial spillovers" scenario the expansionary effects from a US monetary policy tightening in the euro area are dominated by the contractionary spillovers through financial markets: Euro area long-term interest rates rise in tandem with those in the US, dampening domestic demand in the euro area.

Figure 7: True Model Impulse Responses to a US Monetary Policy Shock for Parametrisations with and without Financial Spillovers
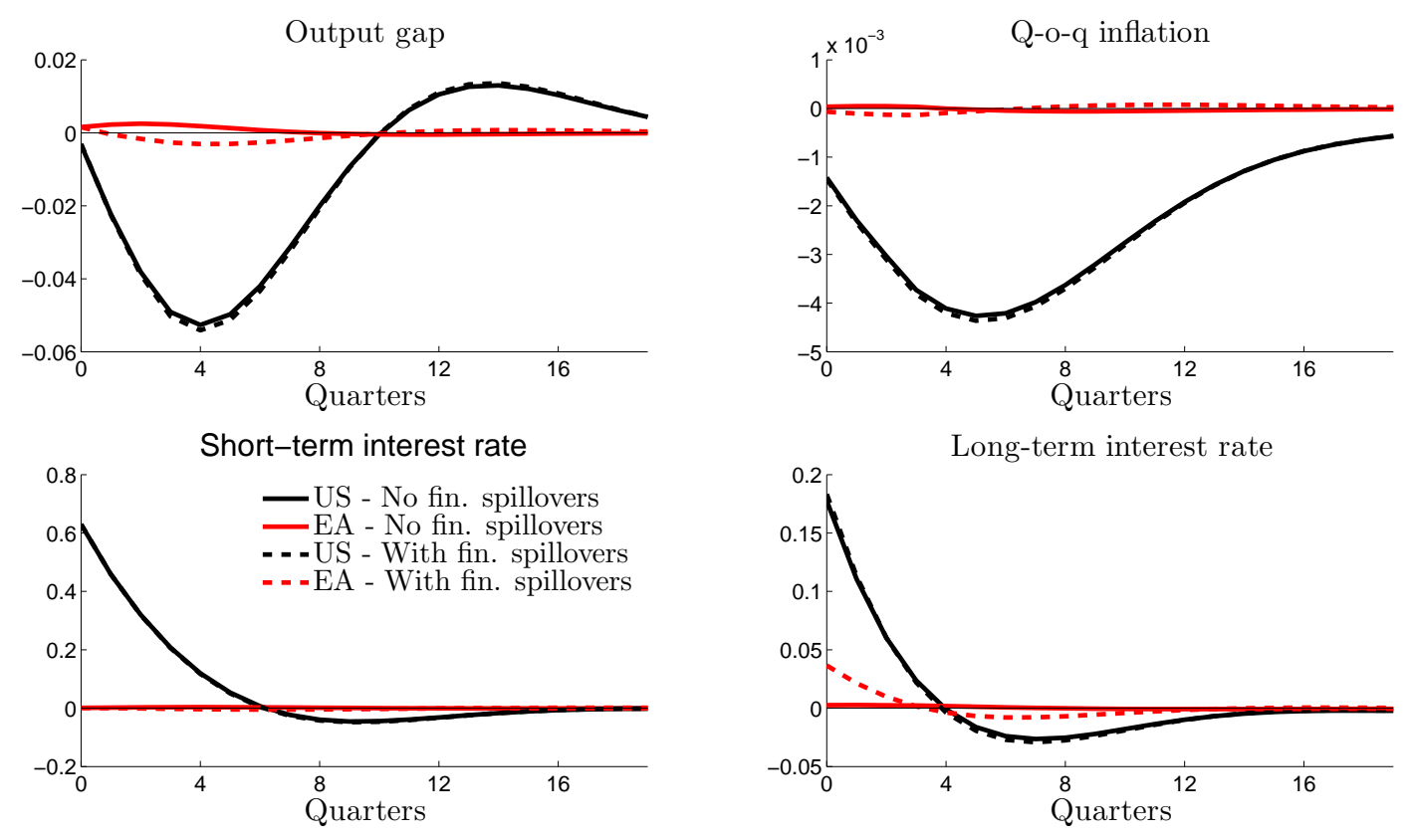

Note: The figure shows the impulse responses of several macroeconomic variables to a US monetary policy shock in the model of Coenen and Wieland (2002) and described in Appendix C.2. The dark black lines represent the responses of the euro area variables, and the light red lines those of the US variables. The solid lines represent the responses under the "no financial spillovers" parametrisation, and the dashed lines those under the "financial spillovers" parametrisation.

Figure 8 displays the responses of the US and the euro area to a contractionary monetary 
policy shock in the euro area. In contrast to the spillovers from US monetary policy, those emitted from the euro area are contractionary both under the "no financial spillovers" and the "financial spillovers" scenarios. This is due to the relatively large susceptibility of US long-term interest rates to foreign shocks in our calibration compared to the polar case of the "no financial spillovers" scenario calibration for the euro area. For the euro area, the domestic impact of a euro area monetary policy shock is smaller under the "financial spillovers" scenario as the transmission from short to long-term interest rates is weaker. This is consistent with the recent "dilemma hypothesis" according to which financial globalisation reduces monetary policy autonomy and effectiveness, partly due to a dampened transmission of short term to long-term interest rates (Ito, 2014; Miyajima et al., 2014; Obstfeld, 2015; Rey, 2015).

Figure 8: True Model Impulse Responses to a Euro Area Monetary Policy Shock for

Parametrisations with and without Financial Spillovers
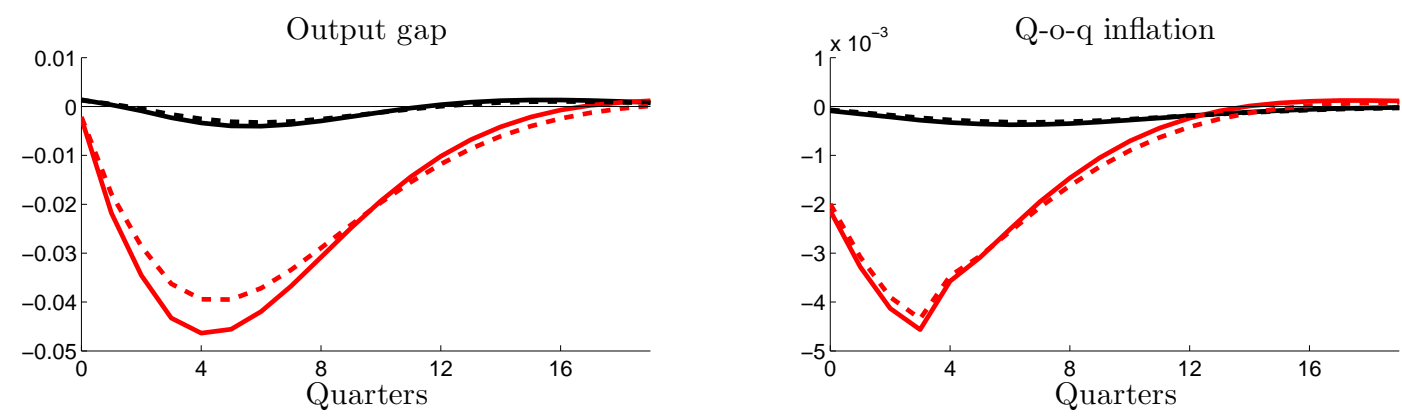

Short-term interest rate
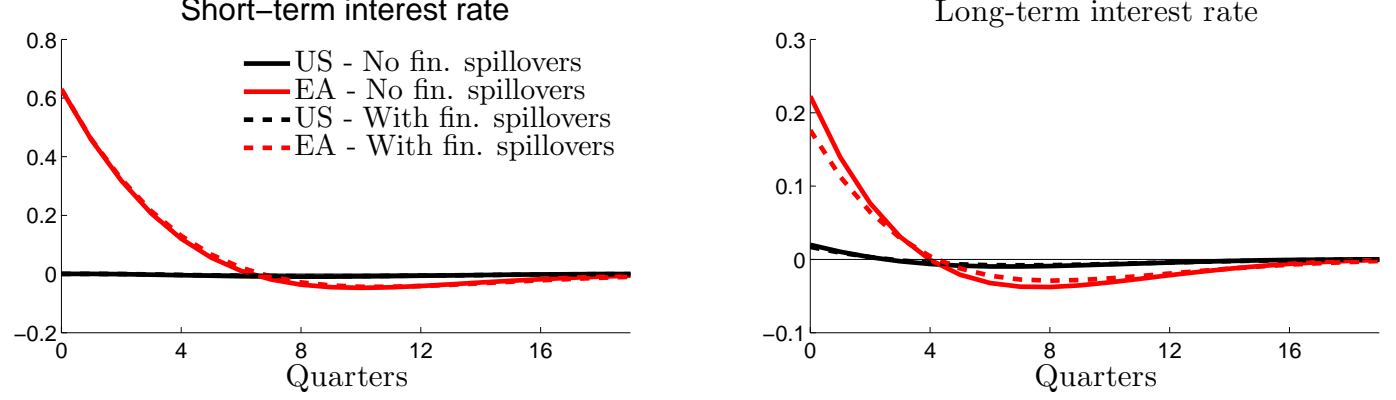

Note: The figure shows the impulse responses of several macroeconomic variables to a euro area monetary policy shock in the model of Coenen and Wieland (2002) and described in Appendix C.2. The dark black lines represent the responses of the euro area variables, and the light red lines those of the US variables. The solid lines represent the responses under the "no financial spillovers" parametrisation, and the dashed lines those under the "financial spillovers" parametrisation. 


\section{C.3 Additional figures}

Figure 9: Economies' International Financial Integration Patterns
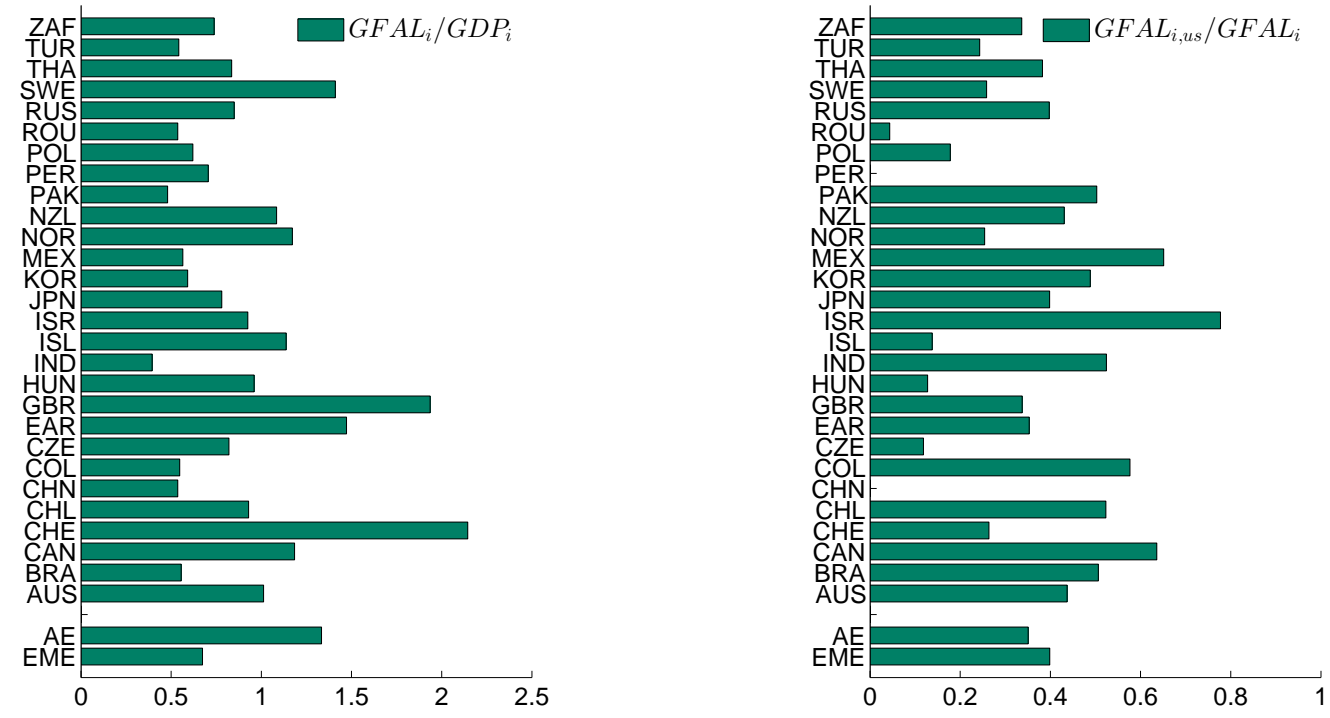

Note: The figure displays economies' gross foreign asset and liability positions relative to GDP (left-hand side panel) as well as the share of economies' gross foreign asset and liability position accounted for by the US (right-hand side panel). The overall gross foreign asset and liability positions are taken from Lane and MilesiFerretti (2007), and the bilateral gross foreign asset and liability positions with the US from the IMF CPIS. The latter refer only to portfolio investment assets and liabilities. The depicted values are averages over the time period from 1993 to 2007 for the left-hand side panel and 2001 to 2007 for the right-hand side panel. The depicted values are one plus the logarithm of the original values. There are no data on portfolio asset holdings for China and Peru in the IMF CPIS. The data on the gross foreign assets and liabilities in the left-hand side panel are not plotted for the US. 